
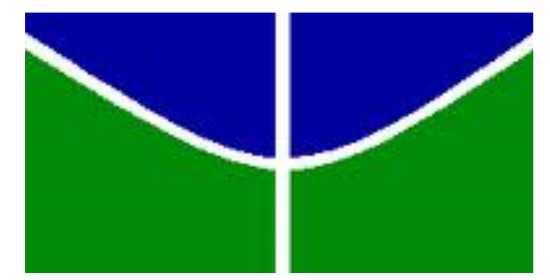

UNIVERSIDADE DE BRASÍLIA

FACULDADE DE DIREITO

CONSTITUCIONALISMO EM FORMAÇÃO NO BRASIL - UMA ANÁLISE DOS DISCURSOS PARLAMENTARES NA ASSEMBLEIA GERAL

CONSTITUINTE E LEGISLATIVA DE 1823

FERNANDO HENRIQUE LOPES HONORATO

BRASÍLIA

2014 


\section{CONSTITUCIONALISMO EM FORMAÇÃO NO BRASIL - UMA ANÁLISE DOS DISCURSOS PARLAMENTARES NA ASSEMBLEIA GERAL} CONSTITUINTE E LEGISLATIVA DE 1823

Dissertação apresentada ao Programa de Pós-Graduação da Faculdade de Direito da Universidade de Brasília para a obtenção do título de mestre em Direito.

Área de concentração: Direito, Estado e Constituição

Linha de pesquisa 2: Constituição e Democracia: Teoria, História, Direitos Fundamentais e Jurisdição Constitucional

Orientador: Prof. Dr. Cristiano Paixão

\section{BRASÍLIA}


Após sessão pública de defesa desta dissertação de mestrado, o candidato foi considerado aprovado pela banca examinadora.

Prof. Dr. Cristiano Paixão

Orientador

Prof. Dr. Arnaldo Sampaio de Moraes Godoy (UNICEUB)

Membro

Prof. Dra. Cláudia Rosane Roesler (FD-UnB)

Membro

Prof. Dr. Mamed Said Maia Filho (FD-UnB)

Suplente

Brasília

2014 
Para João Felipe e Maria Fernanda, pedaços de mim. 


\section{AGRADECIMENTOS}

Os agradecimentos às inúmeras pessoas que direta ou indiretamente exerceram um importante papel durante o meu percurso no curso de mestrado na Universidade de Brasília é também uma forma de recordar. Ao lembrar de todos, lembro de mim. E assim me dou conta de que não sou mais eu, não sou mais um. Da mesma forma a dissertação elaborada também não pode ser somente minha. $\mathrm{Na}$ verdade nunca foi. Desde a primeira palavra escrita ela deixou de ser fruto da minha imaginação, (in)consciência e horas e mais horas de leituras e pesquisas e passou a ser de quem a leu e ainda vai ler. Recordo bem de um texto de Barthés, para quem o autor morreu, restando somente o leitor. Assim, antes de mais nada, preciso agradecer por ter a oportunidade de agradecer e com isso eternizar também estas memórias felizes. Obrigado!

Tal como o mestrado dividiu-se entre os dois lados do Atlântico, os agradecimentos também seguirão essa mesma lógica, ainda que não seja possível ordenar o fluxo das lembranças, pois, como adverte Borges, "La memoria del hombre no es una suma; es un desorden de posibilidades indefinidas". Seguiremos o caminho

inverso de Cabral e, partindo do Brasil chegaremos a Portugal, mas ao final descobrirme-ei a mim mesmo.

Eu me lembro como se fosse hoje quando pisei pela primeira vez na UnB e a sensação mágica que aquele lugar despertou em mim. Em meio à tensão da espera da realização de uma prova oral de concurso público que seria realizada no Auditório da Faculdade de Direito, consegui encontrar equilíbrio e paz descansando meu olhar no horizonte do Lago Paranoá, após perder-se entre os prédios da FA e o ICC Norte. E pouco tempo após a aprovação no referido certame eu só pensava em voltar ali e sentir 
de novo aquela energia. Foi assim que, em 2009, entre coragem e insegurança, ou, parafraseando Saramago, entre o temor de ir e o desejo de chegar, sem conhecer nada nem ninguém, resolvi ir até a Universidade e, meio sem graça, acabei entrando em uma sala onde um professor falava com entusiasmo sobre um tal de Giorgio Agamben e o que era o contemporâneo.

Como não poderia deixar de ser, portanto, minha primeira palavra de agradecimento é dirigida a esse professor, que depois se tornou meu orientador e, porque não dizer, um bom amigo. O que ele não podia desconfiar é que carrega no sobrenome o sentimento que me move. Obrigado por abrir as minhas janelas da alma e possibilitar um olhar para um horizonte mais distante, estimulando novas leituras, o aprendizado de novos idiomas, a apreciação de outros tipos de musicalidades. Agradeço a generosidade, a dedicação, o rigorismo científico e, sobretudo, a imensa paciência com que conduziu o processo de orientação, tanto mais árduo quanto maiores eram - e são - as minhas próprias limitações. Muito obrigado professor, orientador, amigo, Cristiano Paixão!

$\mathrm{Na}$ Universidade fiz outros bons amigos entre funcionários, professores e alunos. Assim, devo um agradecimento especial à Euzilene, Lia, João, Kelly e Helena que facilitaram muito o meu caminho no interior labiríntico dos assuntos administrativos da UnB, sempre com um sorriso estampado no rosto, fazendo, também, assim, meus dias mais felizes! Muito obrigado! Aos professores, todos, agradeço os ensinamentos, que vou levar para toda a vida, mas, em particular, eu gostaria muito de agradecer ao professor Menelick de Carvalho Netto, que, sempre generoso, emprestou-me algumas horas dos seus tão atribulados afazeres, para discussão dos projetos de pesquisa e meu amadurecimento como pesquisador. Não posso deixar de agradecer também ao professor do Departamento de História da UnB, José Otávio Guimarães, por acreditar na 
minha vocação de pesquisador em história do direito e sempre incentivar as pesquisas. Muito obrigado meus eternos mestres!

Aos amigos do grupo de pesquisa "percursos, fragmentos, narrativas", a força de vocês me fez mais forte! Cláudia Paiva Carvalho, Douglas Pinheiro, Gabriel Rezende, Guilherme Cintra, Eneida Dutra, Leonardo Barbosa, Mamede Said Filho, Maria Celina, Maria Pia, Mariana Barbosa Cirne, Mateus Utzig, Noêmia Porto, Rafael Cabral, Raphael Peixoto, Renato Bigliazzi, Ricardo Lourenço Filho, Rogério Madeira, Thaís Faria e demais integrantes não citados nominalmente, muito obrigado! As reuniões para discussão do projeto de pesquisa, as sugestões de aperfeiçoamento do texto, a indicação de preciosas leituras, o acolhimento carinhoso e até mesmo o conforto do silêncio que comunica, cada gesto, pura e simplesmente nunca serão por mim esquecidos! Obrigado por tudo isso e muito mais, por fazerem parte da minha vida!

Uma palavra especial de agradecimento aos membros da banca examinadora, Prof. Dr. Arnaldo Godoy e Prof. Dra. Cláudia Roesler, que elevaram, com sua sabedoria, generosidade e percucientes arguições, a qualidade do meu trabalho! Certamente este será um daqueles dias em que, tal como Funes, eu me lembrarei de cada forma das nuvens, mas, ao contrário de Irineo, à noite eu consegui distrair-me do mundo e dormir, feliz!

O mestrado na Universidade de Brasília ainda me proporcionou outra experiência transformadora. Através dos Convênios Internacionais da UnB foi possível cumprir uma etapa do curso na Universidade de Coimbra, onde, durante aproximadamente seis meses, vivenciei uma imersão na cultura portuguesa, conhecendo pessoas e lugares que vou carregar comigo pra sempre. Entre os bancos tradicionais da Faculdade de Direito - FDUC, as escadas da Faculdade de Letras - a FLUC, e o Centro de Estudos Sociais - CES, tive o prazer e a honra de conhecer grandes almas 
portuguesas e brasileiras, nem sempre habitando corpos distintos.

Obrigado ao Prof. Dr. Mario Reis Marques, que gentilmente aceitou-me como seu aluno na seleta e diminuta turma da disciplina Codificação e Cultura Jurídica, ministrada no âmbito do Programa de Doutoramento em direito. Agradeço da mesma forma aos colegas doutorandos Adolpho Ribeiro, Christiane Carneiro, Eduardo Maia, Fernando Cáceres, Jorge De Seabra, Maria Lygia, Matheus Caetano, Neylene Fonseca e Silvagner Azevedo pelo acolhimento.

Agradeço muito especialmente ao Prof. Dr. Fernando Catroga pelos ensinamentos na disciplina Teoria da História, ministrada no âmbito da Licenciatura em história, bem como durante a longa sessão de orientação reservada, em que me recebeu em seu gabinete no Instituto de História das Ideias, "deu-me pernas para andar" indicando vasta bibliografia e apontou-me o rumo a seguir dali em diante na pesquisa sobre a formação do constitucionalismo em Portugal e no Brasil. Mas, sobretudo, professor, falando em bom português lusitano, "eu gostava" de agradecer pela possibilidade de desfrutar da sua gentil companhia durante os deliciosos cafés da FLUC e ainda pela generosidade imensa de aceitar o convite para compor a banca de defesa da minha dissertação de mestrado, o que, infelizmente, por razões de ordem burocrática, não se pode concretizar! "Para o Fernando, do Fernando", muito obrigado!

Durante o mestrado-sanduíche na Universidade de Coimbra, além das referidas disciplinas, ainda frequentei algumas outras como aluno ouvinte, como a disciplina Introdução ao pensamento jurídico contemporâneo, ministrada pelo Prof. Dr. Aroso Linhares, além de ter participado de vários seminários, palestras e cursado língua e cultura francesa no Centro de Línguas Estrangeiras. Não obstante, os agradecimentos vão ficar por conta dos amigos feitos no Programa de Doutoramento em Direito, Justiça e Cidadania no Século XXI, no âmbito do CES, onde frequentei alguns seminários 
sobre o tema do acesso à justiça.

Muito obrigado Fernando Perazzoli, Flávia Carlet, Herta, Manuel, Marcelo Politano, Nathalie, Natascha, Péricles, Wérika Lopes, Waterloo e Ximena pelo carinho, pela amizade, pelos cafés na Almedina, no Bossa Nova, no Machado de Castro, pelos jantares da Rua dos Combatentes, pelas caminhadas entre a Universidade e a Faculdade de Economia - onde eram ministrados os seminários do referido Programa de Doutoramento - na Avenida Dias da Silva, passando pelo Jardim Botânico e pelo Penedo da Saudade, pelas tardes de estudo na Casa da Escrita e na Biblioteca Central, obrigado, enfim, por aumentarem ainda mais o encanto de Coimbra! Agradeço ainda pelos amigos que conheci através de vocês e cuja amizade acabou por atravessar o oceano, Rui Calado, Débora Dias e sua formidável Marina!

O "sítio" da Rua António Jardim, 171, $3^{\circ}$ esquerda também vai deixar saudades! Beto, Ricardo, Gonçalo, Joel, Rony, Rúben, Nil, vocês foram a minha família em Portugal! Muito obrigado por terem suportado meu mau humor, alegrado meus dias e noites com os famosos jantares do Beto e do Ricardo ou no Clube dos Olivais, sempre regados do melhor vinho português, especialmente aqueles da safra do tio do Gonçalo, ou de uma boa e gelada super bock! Até mesmo fazer compras no Jumbo no Dolce Vita era uma diversão com vocês! Meus amigos, irmãos, companheiros, muito obrigado! Vou levar vocês pra sempre!

Agradeço aos meus pais José João e Maria Regina, pelo apoio e incentivo de sempre! Aos meus irmãos Carlos Eduardo e Luís Felipe, pela parceria de uma vida inteira! Agradeço à Defensoria Pública do Distrito Federal, que proporcionou as condições necessárias para a realização do mestrado-sanduíche em Portugal, especialmente aos meus colegas do Núcleo de Atendimento Jurídico de Samambaia e aos Defensores Públicos da Vara Regional de Atos Infracionais. 
Por fim, toda essa grande experiência só foi possível graças ao meu porto seguro: minha família. Assim, agradeço muito especialmente à Karina, a mulher da minha vida! Obrigado por sorrir e sofrer junto comigo as angústias do processo de elaboração da dissertação! Obrigado por suportar minha ausência, mesmo presente, tantas vezes! Obrigado por se manter firme - e a mim - mesmo quando já quase não havia mais forças! Obrigado por cuidar dos nossos filhos, amor maior, João Felipe e Maria Fernanda, com todo carinho, zelo, sempre e tanto! Hoje estou certo de que não sou mais a mesma pessoa de 2009. Trago na bagagem da vida todo o conhecimento adquirido durante esses anos todos de mestrado, mas um núcleo essencial permaneceu imutável e esse pedaço de mim é essencialmente você! 


\section{RESUMO}

O presente estudo é fruto de parte das pesquisas realizadas sobre a história dos conceitos de constituição e constitucionalismo no Brasil no contexto do processo de independência político-jurídica em relação a Portugal, precisamente com a experiência de uma Assembleia Geral Constituinte e Legislativa em 1823. A partir da análise dos discursos dos parlamentares fundadores, propõe uma investigação histórica sobre a (in)definição da forma constitucional e sua estabilização, bem como sobre a seleção dos conteúdos que deveriam integrar a constituição, inundados pelos campos de experiência dos congressistas constituintes e pelos horizontes de expectativas em relação ao EstadoNação em gestação.

Para tanto, as principais fontes primárias utilizadas na pesquisa foram os Diários da Assembleia Constituinte brasileira de 1823 e das Cortes de Lisboa de 1821/1822, os instrumentos legais editados no Brasil e em Portugal no período estudado, bem como alguns periódicos da época, como o Correio Braziliense, o Diário Constitucional, o Revérbero Constitucional Fluminense e outros. Além disso, as fontes secundárias iluminaram a história dos conceitos utilizados, como a própria noção de constituição e constitucionalismo, cujo uso indiscriminado conduzia a uma disputa de sentidos como verdadeiros artefatos para a conquista de posições ideológicas muito bem definidas.

Neste ambiente permeado de incertezas e interesses antagônicos, a autoatribuição de poderes legislativos pelos constituintes da Assembléia brasileira de 1823, bem como a inclusão no projeto de constituição, de forma inédita na recente história do constitucionalismo moderno, de um artigo que "flexibilizava" a reforma de algumas normas constantes no texto constitucional, mantido posteriormente na Carta 
Constitucional outorgada por D. Pedro I em 1824, sob a forma do artigo 178, surgiam como mais uma possibilidade de compreensão de sentido da constituição.

Palavras-chave: história dos conceitos, constituição, constitucionalismo, independência do Brasil, Assembleia Geral Constituinte e Legislativa de 1823. 


\begin{abstract}
This study is the result of some of the research on the history of the concepts of constitution and constitutionalism in Brazil in the context of political and legal independence from Portugal, precisely with the experience of a Constituent and Legislative General Assembly in 1823. From the analysis of parliamentary speeches of Brazilian founding fathers, offers a historical survey of the (in)definition of the constitutional order and its stabilization as well as on the selection of content that should be part of the constitution, inundated the fields of expertise of the participants and constituents horizons of expectations of the nation-state in pregnancy.
\end{abstract}

The main primary sources used in the research were the Daily Brazilian Constituent Assembly of 1823 and the Cortes of Lisbon of 1821/1822, legal instruments in Brazil and Portugal edited in the period studied, and some periodicals of the time, as the Correio Braziliense, the Diário Constitucional, the Revérbero Constitucional Fluminense and others. In addition, secondary sources illuminated the history of concepts used, as the notion of constitution and constitutionalism, which led to indiscriminate use genuine dispute senses as true artifacts for achieving well-defined ideological positions.

In this environment permeated with uncertainty and antagonistic interests, the self-attribution of legislative powers by the Brazilian Constituent Assembly of 1823, as well as the inclusion in the project of constitution, as never before in the recent history of modern constitutionalism, an article that limb the reform of certain rules contained in the Constitution, held later in the Constitutional Charter granted by D. Pedro I in 1824, in the form of Article 178, emerged as another possibility of understanding towards the constitution. 
Key words: history of concepts, constitution, constitutionalism, Brazil's independence, Constituent and Legislative General Assembly of 1823. 
"Soldados! Não é só no campo de batalha que se adquire immortal glória (...) Vós sereis responsáveis perante Deus, perante o mundo e perante as cortes de Portugal, de qualquer omissão ou falta de energia de que se possa aproveitar o sistema anticonstitucional."

Proclamação in MORAES, Alexandre José de Mello. História do Brasil-Reino e do Brasil-Império. t. 1. São Paulo: Ed. Universidade de São Paulo, 1982, p. 163. 
SUMÁRIO

Introdução 1

Capítulo 1 - PORTUGAL E BRASIL, 1820-1823: CONSTITUCIONALISMO EM CONSTRUÇÃO 6-50

1.1. REVOLUÇÃO DO PORTO: DEBATES CONSTITUCIONAIS 6

1.2. BRASIL: NO CAMINHO PARA A ASSEMBLEIA CONSTITUINTE 32

Capítulo 2 - VOCABULÁRIO POLÍTICO-CONSTITUCIONAL DA ASSEMBLEIA GERAL CONSTITUINTE E LEGISLATIVA DO BRASIL $51-120$

2.1. CONSTITUIÇÃO COMO CONTRATO: O USO DA IDEIA DE PACTO SOCIAL NOS DEBATES 57

2.2. SUPREMACIA DA CONSTITUIÇÃO: ELEMENTOS DA DISCUSSÃO 80

Considerações finais 121

Fontes Documentais e Bibliografia $125-146$ Arquivos 125

Documentação Impressa 125

Bibliografia Geral 131 


\section{INTRODUÇÃO}

O processo de independência política do Brasil em relação ao Reino Unido de Portugal, Brasil e Algarves constitui o que alguns historiadores denominam de "tempos quentes da história" ${ }^{\text {, }}$ tendo se iniciado muito tempo antes da declaração de D. Pedro I em 1822 e terminado muito tempo depois dela, com nuances políticas, econômicas e jurídicas que lhe conferem uma enorme complexidade e no qual o uso de um termo novo vai adquirir um significado especial nessa verdadeira batalha: constituição.

A partir das Revoluções Americana e Francesa, países como Espanha, Portugal e suas então colônias na América passaram a utilizar com frequência cada vez maior o vocábulo constituição como expressão de sua liberdade ou, ainda melhor, de seu anseio por libertação e independência. Os sentidos em que se deram esses usos no processo de independência do Brasil constituem o objeto de nossas reflexões na presente dissertação.

As referências feitas ao constitucionalismo nos EUA, França e Inglaterra deverão servir tão somente de suporte para a identificação do instrumental teórico e semântico de que se valeram os homens que participaram do processo de independência do Brasil, em uma espécie de arqueologia do conceito de constituição ${ }^{2}$, sem pretensão alguma de discutir os limites e possibilidades que estes movimentos constitucionais podem representar para a história em geral e para a história do direito e do constitucionalismo em particular. A história do direito conta com inúmeros trabalhos de

\footnotetext{
1 CATROGA, Fernando. "Quimeras de um façanhoso império": o patriotismo constitucional e a independência do Brasil in Memória, escrita da história e cultura política no mundo luso-brasileiro. Rio de Janeiro, Ed. FGV, 2012, p. 327.

${ }^{2}$ PAIXÃO, Cristiano; BIGLIAZZI, Renato. História constitucional inglesa e norte-americana: do surgimento à estabilização da forma constitucional. Brasília: Ed. Universidade de Brasília: Finatec, $1^{\text {a }}$ reimpressão, 2011.
} 
autores variados, que já muito contribuíram para o aprendizado sobre o referido período $^{3}$.

O Capítulo 1 do trabalho vai se ocupar dos textos e contextos que marcaram o constitucionalismo no processo de independência brasileira, estabelecendo como marco temporal inicial a Revolução do Porto, havida em 24 de agosto de 1820, passando pelos movimentos constitucionais na Bahia e no Rio de Janeiro em 1821, que culminaram com a convocação de uma Assembleia Geral Constituinte e Legislativa do Brasil em 1822. Por certo, as análises não obedecerão a um critério temporal estático, inflexível, na medida mesmo em que qualquer análise histórica implica necessariamente uma abertura para o futuro e para o passado $^{4}$, permitindo (ou, ainda melhor, exigindo) ao pesquisador movimentos de avanço e recuo no tempo para melhor compreensão dos fenômenos que se pretende estudar.

Antes mesmo de o Brasil conhecer a sua primeira Constituição em 1824, esse termo já era conhecido e utilizado por homens como o próprio D. Pedro I, que, ao

\footnotetext{
${ }^{3}$ Cf. BAILYN, Bernard. As Origens Ideológicas da Revolução Americana. Trad. Cleide Rapucci. Bauru: Edusc, 2003; DIPPEL, Horst. História do Constitucionalismo Moderno: Novas Perspectivas. Trad. António Manuel Hespanha e Cristina Nogueira da Silva. Lisboa: Fundação Calouste, 2007; do mesmo autor, cf. ainda: Inglaterra, Estados Unidos e França: Constitucionalismo e Soberania Popular; El concepto de constitución em los orígenes del constitucionalismo norteamericano (1774-1776). Revista Fundamentos, $\mathrm{n}^{\circ}$ 6, 2010, pp. 25-83; O pensamento democrático na América e na França na época revolucionária: unidade e divergências. Tradução de José Emílio Medauar Ommati. s/ referências; As ideias constitucionais americanas e francesas na Alemanha no final do Século XVIII; O surgimento do constitucionalismo moderno e as primeiras constituições latino americanas. Tradução de Paulo Sávio Peixoto Maia. s/ referência; FIORAVANTI, Maurizio. Costituzione, a cura di Carlo Galli, Il Mulino, Bologna, 1999; HESPANHA, António Manuel. Guiando a mão invisível. Direitos, Estado e lei no liberalismo monárquico português. Coimbra: Editora Almedina, 2004; do mesmo autor: Panorama Histórico da cultura jurídica européia. Publicações Europa-América, Sintra, 1997; LUHMANN, Niklas. "La Constituzione come acquisizione evolutiva". ZAGREBELSKY, Gustavo; PORTINARO, Pier Paolo e LUTHER, Jörg (org.). Il Futuro dela Costituzione. Torino: Einaudi, 1996; PAIXÃO, Cristiano; BIGLIAZZI, Renato. História constitucional inglesa e norte-americana: do surgimento à estabilização da forma constitucional. Brasília: Ed. Universidade de Brasília: Finatec, $1^{a}$ reimpressão, 2011; SOARES, Rogério Ehrhardt. O conceito ocidental de Constituição. Revista de Legislação e Jurisprudência, 3743 e 3744, Coimbra Editora, Coimbra, 1987, p. 36-39 e 69-73.

STOURZH, Gerald. "Constitution: Changing Meanings of the Term from the Early Seventeenth to the Late Eighteenth Century". BALL, Terence; POCOCK, J.G.A.. Conceptual Change and the Constitution, Lawrence KS, 1988, p. 35-54.

${ }^{4}$ CARVALHO NETTO, Menelick de. A sanção no procedimento legislativo. Belo Horizonte: Del Rey, 1992.
} 
convocar o Conselho de Procuradores-Gerais das Províncias em 1822, expressamente se valeu da expressão para afirmar que o fazia para que os brasileiros melhor conhecessem a sua "constitucionalidade". Por outro lado, a participação, em 1821 e 1822, de deputados brasileiros nas Cortes Gerais e Extraordinárias da Nação Portuguesa, representando suas províncias e o Brasil, conferia algum ar de familiaridade com os sentidos de termos como constituição e constitucionalismo, eles próprios ainda em construção.

As bases do Governo Provisório da República de Pernambuco, formuladas no bojo da Revolução de 1817, que teve como um dos protagonistas o futuro relator do projeto de Constituição, elaborado pela Comissão de Constituição da Assembleia Constituinte de 1823, Antônio Carlos Ribeiro de Andrada Machado e Silva; o juramento de D. João VI e sua corte, em fevereiro de 1821, à futura Constituição que seria elaborada pelas Cortes Gerais e Extraordinárias da Nação Portuguesa; a aprovação das bases constitucionais em março do mesmo ano e, posteriormente, em setembro de 1822 , da própria Constituição portuguesa; e, ainda, o episódio da vigência no Brasil da Constituição espanhola de Cádiz por um dia, por meio do decreto de D. João VI de 21 de abril de 1821, dão uma pequena amostra de como aquele vocábulo novo constituição - estava de algum modo já inserido na vida política do Brasil e dos homens que participaram do processo de independência brasileira antes mesmo que vigorasse no Brasil a sua primeira Carta Constitucional.

No Capítulo 2 nossa atenção será concentrada no estudo das sessões da Assembleia Geral Constituinte e Legislativa de 1823. Neste ponto, serão analisadas principalmente as fontes primárias selecionadas para a pesquisa, consistentes nos Diários da Assembleia, bem como em alguns periódicos publicados nesta época, como 
o Correio Braziliense, o Revérbero Constitucional Fluminense, A Malagueta, o Correio do Rio de Janeiro, O Espelho, O Tamoio, A sentinela da Liberdade e outros.

A própria indeterminação semântica do termo "constituição" deu azo à inclusão, no texto do projeto de Constituição acima mencionado, do que veio a ser o artigo 178 da Carta Constitucional de 1824, segundo o qual somente seria constitucional o que dissesse respeito aos limites e atribuições dos poderes públicos e aos direitos políticos e individuais dos cidadãos e tudo o mais não seria, ainda que constasse expressa e formalmente no texto constitucional, o que implicava um processo diferente de reforma constitucional e legislativa.

As relações entre forma e conteúdo constitucionais e as incertezas quanto à extensão de significados de uma e outro, possibilitaram aos constituintes de 1823 a adoção de uma fórmula mista, posteriormente aproveitada por D. Pedro I (como, de resto, praticamente, todo o chamado Projeto Antônio Carlos), em que diversos assuntos considerados importantes para a consolidação do processo de independência do Brasil foram inseridos no texto constitucional, ainda que materialmente pudessem ser considerados destituídos dessa envergadura, possibilitando uma futura reforma pelas legislaturas ordinárias, sem as formalidades exigidas para a alteração das normas de conteúdo eminentemente constitucionais.

Duas notas explicativas. $\mathrm{Na}$ análise dos debates da Assembleia Geral Constituinte e Legislativa do Brasil, em diversas passagens são feitas referências diretas aos discursos dos deputados constituintes. Assim, a fim de facilitar a identificação dos personagens, optamos por usar uma fórmula que repete a forma pela qual os deputados são referidos nas Atas da Assembleia, sempre pelo sobrenome, seguida do seu nome completo na primeira ocorrência no nosso texto. Por exemplo, o deputado Luiz Ignácio 
de Andrade Lima é identificado nos pronunciamentos da Assembleia simplesmente como Andrade Lima. Na primeira ocorrência do seu nome neste trabalho é assim que ele será identificado, de maneira completa. A partir de então, sempre que houver nova ocorrência do seu nome, será simplesmente designado por Andrade Lima.

$\mathrm{Na}$ citação literal dos discursos proferidos pelos deputados na Assembleia Constituinte, bem como dos trechos de documentos do período, optamos por adaptar a linguagem utilizada na época para a língua portuguesa praticada atualmente. 


\section{CAPÍtUlO 1 - PORTUGAL E BRASIL, 1820-1823: CONSTITUCIONALISMO EM CONSTRUÇÃO}

\subsection{REVOLUÇÃO DO PORTO: DEBATES CONSTITUCIONAIS}

Em 1881, Clemente José dos Santos, taquígrafo da Câmara dos Deputados de Portugal, passou a colher e organizar uma estatística geral e histórica do parlamento português, que acabou originando uma das mais importantes e completas fontes do constitucionalismo português no Século XIX, intitulada "Documentos para a História das Cortes Gerais da Nação Portuguesa”, publicada em 1883. Nela, o autor assevera que "a mudança de regime político que as revoluções operaram em algumas potências da Europa no princípio do presente século, as ideias liberais transmitidas pela imprensa e centenas de opúsculos estrangeiros, repercutiram em Portugal" ${ }^{, 5}$, com destaque para o Sinédrio, um pequeno clube revolucionário, que, impulsionado pelo êxito da Revolução de Cádiz em 1812, teve grande preponderância sobre os acontecimentos de 1820, infundindo as suas opiniões liberais no espírito da maioria dos portugueses influentes na época, inclusive entre a cúpula do exército, cuja corporação militar do Porto ficou encarregada de "erguer o primeiro brado em prol das instituições monárquicorepresentativas e constitucionais"

O movimento vintista, como ficou conhecido, deve ser entendido no contexto de descontentamento generalizado com a situação coadjuvante política e econômica que Portugal passou a experimentar em relação à centralidade ocupada pelo Brasil desde a transferência da corte em 1808; a precariedade do estado social decorrente das recentes

\footnotetext{
${ }^{5}$ Clemente dos Santos (org.). Documentos para a História das Cortes Gerais da Nação Portuguesa. (vol. 1), Porto, p. 5.

${ }^{6}$ Clemente dos Santos (org.). Documentos para a História das Cortes Gerais da Nação Portuguesa. (vol. 1), Porto, p. 5.
} 
guerras externas, com França, Espanha e, mais recentemente, o jugo inglês em solo português; aliada à crença de que o anseio por mudanças somente poderia ser concretizado por meio de uma constituição a ser elaborada por Cortes Extraordinárias especialmente convocadas para esse fim.

Nestas circunstâncias é que a cúpula do exército no Porto reuniu-se a portas fechadas na noite do dia 23 de agosto de 1820, na casa do coronel do regimento de infantaria $\mathrm{n}^{\circ} 18$, Bernardo Correia de Castro e Sepúlveda, decidindo formar a tropa no Campo de Santo Ovídio ainda na madrugada do dia 24 de agosto para dar-lhes conhecimento das Proclamações acertadas horas antes, em que anunciavam a criação de um Governo Provisório, que deveria convocar as Cortes para ser o órgão da Nação e preparar uma Constituição para garantia dos direitos dos portugueses, incitando os soldados a resguardar a ordem, coibindo os tumultos e abafando a anarquia. Segundo Clemente dos Santos, "a tropa e o numeroso povo que lhe agregara correspondera àqueles brados dos dois coronéis e a artilharia deu uma salva de vinte e um tiros, como sinal de estar proclamada a liberdade no solo português"7.

Logo em seguida, no paço do senado da câmara, reunidos o juiz de fora do cível, o procurador da cidade e do povo e os vereadores, foi anunciada pelo conselho militar a formação de uma junta provisória depositária do supremo governo do reino, que governaria em nome do Rei D. João VI, mantendo a religião católica e convocando cortes representativas da nação para nelas formar uma constituição ${ }^{8}$.

Ainda no dia 24 de agosto de 1820, a Junta Provisional do Governo Supremo do Reino expediu um Manifesto aos Portugueses, em que, após arrolar as causas da desgraça portuguesa, invocava a memória dos antepassados, que eram:

\footnotetext{
${ }^{7}$ Clemente dos Santos (org.). Documentos para a História das Cortes Gerais da Nação Portuguesa. (vol. 1), Porto, p. 6.

${ }^{8}$ Para a composição da Junta Provisória do Supremo Governo do Reino, ver Clemente dos Santos (org.). Documentos para a História das Cortes Gerais da Nação Portuguesa. (vol. 1), Porto, p. 7.
} 
“felizes, porque viveram nos séculos venturosos, em que Portugal tinha um governo representativo nas Cortes da nação e obraram prodígios de valor, enquanto obedeciam às leis que elas sabiamente constituíram, leis que aproveitavam a todos porque a todos obrigavam ... nunca a religião, o trono e a pátria receberam serviços tão importantes; nunca adquiriram, nem maior lustre, nem mais sólida grandeza, e todos estes bens dimanavam perenemente da constituição do estado, porque ela sustentava em perfeito equilíbrio e na mais concertada harmonia os direitos do soberano e dos vassalos, fazendo da nação e de seu chefe uma família só, em que todos trabalhavam para a felicidade geral". 9

O Manifesto aos Portugueses deposita todas as esperanças de um Portugal melhor na sua constituição antiga. Com isso, pretende buscar no passado uma solução para os problemas daquele momento, sem, no entanto, uma ruptura total com a forma de governo - na medida mesmo em que pretendia a preservação da monarquia como forma de governo, doravante, porém, mediado pela representação da nação pelas Cortes. Pereira das Neves revela que um periódico português, editado em 16 de agosto de 1819, um ano antes da Revolução no Porto, contrapunha os direitos do povo aos direitos do soberano, fundados nas Cortes de Lamego, "a Magna Carta portuguesa" e nas Cortes de Coimbra de $1385^{10}$.

Assim é que exclamava a Junta Provisional “tenhamos, pois, essa constituição, e tornaremos a ser venturosos!"11 e anunciava a convocação imediata de Cortes, nos seguintes termos: "Imitando nossos maiores, convoquemos as Cortes e esperemos da sua sabedoria e firmeza as medidas que só podem salvar-nos da perdição e segurar nossa existência política"12.

O Manifesto aos Portugueses deixava claras as linhas de continuidades e rupturas que o movimento constitucionalista do Porto pretendia implementar. A

\footnotetext{
${ }^{9}$ Manifesto aos Portugueses. In: Clemente dos Santos (org.). Documentos para a História das Cortes Gerais da Nação Portuguesa. (vol. 1), Porto, p. 9-10.

${ }^{10}$ O Campeão Portuguez, Amigo do rei e do povo. n ${ }^{\circ} 4,16$ de agosto de 1819. Apud NEVES, Lúcia Maria Bastos Pereira das. Corcundas e constitucionais: a cultura política da independência (1820-1822). Rio de Janeiro: REVAN: FAPERJ, 2003, p. 235.

${ }^{11}$ Manifesto aos Portugueses. In: Clemente dos Santos (org.). Documentos para a História das Cortes Gerais da Nação Portuguesa. (vol. 1), Porto, p. 10.

${ }^{12}$ Manifesto aos Portugueses. In: Clemente dos Santos (org.). Documentos para a História das Cortes Gerais da Nação Portuguesa. (vol. 1), Porto, p. 10.
} 
novidade repousava na adoção de um sistema constitucional, por meio da Constituição a ser elaborada pelas Cortes, ao mesmo tempo em que invocava o passado como sua fonte de legitimidade. Asseverava que "nenhuma lei ou instituição humana é feita para durar sempre", mas observava que "a mudança que fazemos não ataca as partes estáveis da monarquia", como a religião e as leis do reino, aduzindo ainda que "as mesmas ordens, os mesmos lugares, os mesmos ofícios, o sacerdócio, a magistratura, todos serão respeitados no livre exercício da autoridade que se acha depositada em suas mãos"13.

A Junta Provisional do Supremo Governo do Reino expede uma proclamação aos habitantes de Lisboa, esperando a sua adesão ao movimento constitucional de "regeneração" de Portugal, bem como outra proclamação aos habitantes do Porto, em que, mais uma vez, a invocação do passado se faz presente para justificar o anseio por uma constituição. Assim, anunciava que "desde 1641 se apagara o facho da representação nacional pelo abandono da congregação de cortes, pedra angular de nossa segurança política" e só uma nova convocação das Cortes seria capaz de restaurar essa segurança política e assegurar uma justiça social, pois "seus foros e direitos (da nação) são a representação nacional devidamente congregada em Cortes". ${ }^{4}$

Os Governadores do Reino ${ }^{15}$, tão logo tiveram ciência do levante do exército no Porto, em 29 de agosto de 1820, expediram uma Proclamação aos Portugueses, como o fito de coibir a "onda revolucionária”, em que advertiam ser ilegal a convocação das Cortes "quando não forem chamadas pelo soberano"16. Logo em seguida, porém, a 01 de setembro do mesmo ano, expediram nova Proclamação, desta vez, convocando eles próprios as antigas cortes e "nomeando, imediatamente, uma comissão destinada a

\footnotetext{
${ }^{13}$ Manifesto aos Portugueses. In: Clemente dos Santos (org.). Documentos para a História das Cortes Gerais da Nação Portuguesa. (vol. 1), Porto, p. 10.

${ }^{14}$ Proclamação. In: Clemente dos Santos (org.). Documentos para a História das Cortes Gerais da Nação Portuguesa. (vol. 1), Porto, p. 15.

15 Para a composição do Governo do Reino, ver Proclamação. In: Clemente dos Santos (org.). Documentos para a História das Cortes Gerais da Nação Portuguesa. (vol. 1), Porto, p. 17.

${ }^{16}$ Proclamação. In: Clemente dos Santos (org.). Documentos para a História das Cortes Gerais da Nação Portuguesa. (vol. 1), Porto, p. 17.
} 
proceder aos trabalhos necessários para a pronta reunião das mesmas cortes" ${ }^{17}$. Com o fim de "evitar os males iminentes da anarquia, da guerra civil e talvez da dissolução da monarquia" ${ }^{\prime 18}$, os Governadores do Reino acabaram por legitimar as reivindicações do movimento constitucionalista do Porto: a convocação das desejadas Cortes.

Em carta, enviada em 02 de setembro de 1820 ao Rei D. João VI, os Governadores do Reino comunicavam a deliberação de convocação das Cortes, justificando ser esta medida "conforme às leis e usos da monarquia, não derrogados por alguma lei, mas apenas descontinuados desde pouco mais de um século", de modo que "não podia na tal medida considerar-se ofendida a soberana majestade de el-rei nosso senhor" ${ }^{\prime 19}$, dando ensejo a uma controvérsia sobre a legitimidade para a convocação das cortes: se exclusiva do soberano, se delegada aos governadores do reino ou se a nação preservava intacto esse direito em razão do próprio juramento prestado pelo rei.

Os oficiais e soldados da guarnição do Porto, em carta dirigida aos Governadores do Reino em 06 de setembro de 1820, refutam a afirmação de que só o rei podia convocar as cortes, indagando:

\begin{abstract}
"quem convocou as que privaram da pública administração ao desmazelado e inepto Sancho II, depositando-a nas mãos do Conde de Bolonha, depois Afonso III? Quem convocou em Coimbra as que fizeram rei a João I, aquele que era até ali somente mestre de Aviz? Seria por vontade de Afonso VI, que se convocaram em Lisboa as que lhe tiraram o governo da monarquia e o entregaram ao infante que reinou depois com o nome de Pedro II? ... Se nas cortes reside o poder de tomar as medidas de salvar o estado, quando se acha a ponto de perder-se, será possível que a autoridade de as convocar pertença exclusivamente ao soberano, isto é, aquele mesmo que direta ou indiretamente pode ter sido a causa dessa ruína, e que, por isso mesmo, pode ter interesse em impedir o ajuntamento da nação?"20.
\end{abstract}

\footnotetext{
${ }^{17}$ Proclamação. In: Clemente dos Santos (org.). Documentos para a História das Cortes Gerais da Nação Portuguesa. (vol. 1), Porto, p. 19-20.

${ }^{18} \mathrm{Ib}$ idem, p. 20.

${ }^{19}$ Carta. In: Clemente dos Santos (org.). Documentos para a História das Cortes Gerais da Nação Portuguesa. (vol. 1), Porto, p. 28.

${ }^{20}$ Carta. In: Clemente dos Santos (org.). Documentos para a História das Cortes Gerais da Nação Portuguesa. (vol. 1), Porto, p. 32.
} 
Com isso, claramente defendiam que o poder de convocar as Cortes permanecia intacto nas mãos da Nação, conclusão esta que se reforçava ainda mais pelos acontecimentos oito anos antes na Espanha.

Em outra carta, remetida na mesma data aos Governadores do Reino, os oficiais da guarnição do Porto destacam três proposições que as antigas cortes do reino mandaram imprimir em latim e em português e que correram o mundo todo, levando no frontispício a efígie e o nome de D. João IV:

\begin{abstract}
"1 1 . Que o poder régio dos reis está nos povos e repúblicas e delas receberam imediatamente. $2^{\mathrm{a}}$. Que ainda que os povos transferissem o poder nos reis, lhes ficou habitualmente e o podem reassumir quando lhes for necessário para sua conservação. $3^{\mathrm{a}}$. Que podem os reinos e povos privar aos reis intrusos e tiranos, negando-lhes a obediência, submetendo-se a quem tiver legítimo direito de reinar n'eles",21.
\end{abstract}

Desse modo, justificavam a convocação das Cortes pela Junta Provisional do Governo Supremo do Reino "porque só ela é que pode convocar as mesmas Cortes de modo que a nação seja toda competentemente representada, só ela pode fazer com que as Cortes deliberem com independência e livres daquele terror que inspirava o antigo despotismo",22 e demonstravam como Portugal já professava em 1640 as lições de direito público que em 1820 estavam em voga na Europa.

A disputa entre os revolucionários do Porto e os Governadores do Reino foi decisiva para o desfecho dos acontecimentos em Portugal naquele momento, eis que os contendores pretendiam sustentar, cada qual para si, a legitimidade do governo e da convocação das Cortes, marcando muito claramente a posição de cada um. Com efeito, os revolucionários assentaram o direito de convocação das Cortes na Nação, que deveria ser representada por inteiro, ao passo que os Governadores do Reino defendiam que o direito de convocação das Cortes pertencia ao Monarca, mas poderia ser exercido por

\footnotetext{
${ }^{21}$ Carta. In: Clemente dos Santos (org.). Documentos para a História das Cortes Gerais da Nação Portuguesa. (vol. 1), Porto, p. 34.

${ }^{22}$ Carta. In: Clemente dos Santos (org.). Documentos para a História das Cortes Gerais da Nação Portuguesa. (vol. 1), Porto, p. 37.
} 
eles, em razão das instruções governativas deixadas por D. João VI antes de partir para o Brasil.

Além disso, asseveravam, em Proclamação feita nesta data, que as Cortes seriam representadas

"pelos três estados do reino, conforme as leis fundamentais da nossa monarquia, único meio legal de consultar os votos da nação, de atender às suas queixas e de adotar as medidas permanentes e necessárias para estabelecer o antigo edifício da nossa constituição, deteriorado pelo decurso do tempo" 23 .

Pretendendo tranquilizar os que desejavam mudanças no precário estado político, econômico e social a que Portugal estava reduzido desde 1808 , no dia 9 de setembro de 1820, os Governadores do Reino expedem uma Carta de Convocação dos Três Estados do Reino, designando o dia 15 de novembro para a sua reunião em Cortes, ocasião em que cada cidade ou vila deveria ser representada por dois procuradores ${ }^{24}$. A convocação, no entanto, ao invés de unificar o sentimento dos portugueses como pretendia, acirra ainda mais os ânimos e a Junta Provisional do Governo Supremo do Reino decide partir para Lisboa no dia seguinte.

O movimento decisivo para os Governadores do Reino foi a determinação, no dia 15 de setembro, dirigida às forças militares de Lisboa, para que se conservassem nos quartéis até segunda ordem, frustrando a expectativa dos militares de comemorar, como todo ano faziam, a restauração de Portugal após a expulsão das tropas francesas. O receio dos Governadores do Reino era um levante das tropas e a adesão à Junta Provisional, que já se encontrava em Coimbra, desconfiança esta que acabou por desagradar ainda mais os militares de Lisboa, já inclinados a constituírem, também eles, um governo provisório. Com efeito, desobedecendo às ordens recebidas, as tropas se

\footnotetext{
${ }^{23}$ Proclamação. In: Clemente dos Santos (org.). Documentos para a História das Cortes Gerais da Nação Portuguesa. (vol. 1), Porto, p. 38.

${ }^{24}$ Carta de convocação dos três estados do reino. In: Clemente dos Santos (org.). Documentos para a História das Cortes Gerais da Nação Portuguesa. (vol. 1), Porto, p. 40-41.
} 
reuniram na Praça do Rossio e, com o apoio de uma multidão, destituíram os Governadores do Reino de suas funções e instituíram um governo interino, "dando vivas ao rei, às Cortes e à futura Constituição"25.

Clemente dos Santos adverte que "se a notícia dos sucessos do meiado de setembro foi satisfatória para a Junta Provisional, suscitou, contudo, sintomas de dissidência entre os dois governos liberais" ${ }^{26}$, porque o de Lisboa, em suas primeiras declarações não fazia sequer menção aos eventos de 24 de agosto ocorridos no Porto e não se referia à Junta como "governo supremo". Esta animosidade inicial não obstou o prosseguimento da marcha da Junta até Lisboa e, após costurar um acordo em Alcobaça, no dia 01 de outubro a Junta Provisional do Governo Supremo do Reino acabou por incorporar todos os membros do governo interino de Lisboa, dividindo-se em duas seções, uma, sob o mesmo nome e outra, sob o nome de "Junta Provisional Preparatória das Cortes", cujo objeto seria "preparar e dispor, com a maior brevidade possível, tudo o que se julgar necessário para a mais pronta convocação das Cortes" ${ }^{27}$. Era o fim de uma jornada, iniciada em 1808 com a transferência da sede da monarquia portuguesa para o Brasil, e o início de outra: a do constitucionalismo luso-brasileiro ${ }^{28}$.

No dia 06 de outubro, a Junta Provisional Preparatória das Cortes expediu uma Portaria abrindo o prazo de vinte dias para consulta a qualquer pessoa do povo e "não só

\footnotetext{
${ }^{25}$ Para a composição do governo interino de Lisboa, ver Clemente dos Santos (org.). Documentos para a História das Cortes Gerais da Nação Portuguesa. (vol. 1), Porto, p. 51.

${ }^{26}$ Clemente dos Santos (org.). Documentos para a História das Cortes Gerais da Nação Portuguesa. (vol. 1), Porto, p. 54.

${ }^{27}$ Portaria. In: Clemente dos Santos (org.). Documentos para a História das Cortes Gerais da Nação Portuguesa. (vol. 1), Porto, p. 57-58, onde consta ainda a composição das seções após a incorporação dos membros do governo interino de Lisboa, denominadas, como visto, de "Junta Provisional do Governo Supremo do Reino" e "Junta Provisional Preparatória das Cortes".

28 Optou-se aqui pela expressão "constitucionalismo luso-brasileiro" para designar o movimento constitucional iniciado em Portugal, mas logo estendido ao Brasil, conforme será demonstrado no curso do presente trabalho. Cf. a respeito, BARBOSA, Samuel Rodrigues. Indeterminação do constitucionalismo imperial luso-brasileiro e o processo de independência do Brasil, 1821-1822. In: José María Perez-Collados; Samuel Rodrigues Barbosa. (Org.). Juristas de la Independencia. 1ed. Madrid: Marcial Pons, 2012, v. 1, p. 103-129.
} 
às corporações científicas e aos homens conhecidos pela sua profissão literária"29, acerca do melhor modo de organizar a representação nacional em Cortes, "a fim de conciliar a facilidade e economia da convocação com a legitimidade, que só pode deduzir-se do consentimento da nação e conveniente expressão da vontade geral"30 .

Clemente dos Santos aduz que começou a correr um "boato" de que muitas pessoas eram favoráveis à forma antiga de convocação das Cortes, isto é, pelos três estados do reino, razão pela qual, “o juiz do povo julgou do seu dever consultar os membros da Casa dos Vinte e Quatro, cujos votos foram a favor do método prescrito na Constituição Espanhola"31, ou seja:

"os membros das Cortes fossem escolhidos indistintamente da massa geral da nação...devendo ser desprezada toda a ideia de uma convocação das Cortes da maneira antigamente praticada...para se conseguir uma livre constituição adaptada às puras ideias do tempo e às nossas necessidades" ${ }^{32}$.

Tendo conquistado o apoio do exército e da própria Junta Provisional do Governo Supremo do Reino, que, em 31 de outubro, redigiu um Manifesto, publicado em 10 de novembro na folha oficial do governo, em que divulgava as instruções para a eleição dos deputados.

No aludido Manifesto, a Junta Provisional do Governo Supremo do Reino referia-se ao povo como titular da soberania e às Cortes como representantes dessa supremacia, às quais “interpretando e confrontando vossas vontades com a sabedoria da lei eterna, lavrarão com mão generosa e firme a grande carta da vossa liberdade e

\footnotetext{
${ }^{29}$ Portaria. In: Clemente dos Santos (org.). Documentos para a História das Cortes Gerais da Nação Portuguesa. (vol. 1), Porto, p. 76.

${ }^{30} \mathrm{Ib}$ idem, p. 76.

${ }^{31}$ Clemente dos Santos (org.). Documentos para a História das Cortes Gerais da Nação Portuguesa. (vol. 1), Porto, p. 78.

${ }^{32}$ Certidão. In: Clemente dos Santos (org.). Documentos para a História das Cortes Gerais da Nação Portuguesa. (vol. 1), Porto, p. 78-79.
} 
independência, seguríssimos penhores da vossa futura prosperidade"33, ou seja, a Constituição:

“qual a natureza a copiaria do original eterno, cujos caracteres não é dado à tirania apagar, nem à proscrição dos abusos desfazer, nem à versatilidade das idades alterar...tal código criador, que anima o ser político, lhe derrama pelos membros as funções vitais, lhe equilibra as forças, simetriza o todo e caracteriza as bem pronunciadas feições das nações"34.

Além disso, fazia críticas ao antigo sistema de governo, no qual "legislar, executar e julgar confundem-se, não raras vezes, na mesma pessoa, como se a imperfeição do homem participasse dos atributos da divindade, ou se dos caprichos de um devem depender o destino de todos" ${ }^{, 35}$ e era cerceada a liberdade de pensamento e a proteção da propriedade e da segurança pessoal se perdiam em meio a leis multiplicadas e obscuras.

Vale destacar aqui a semântica de constituição utilizada pela Junta no referido Manifesto, como direito natural e código criador, de expressão nitidamente relacionada ao uso antigo da palavra constituição como composição do corpo, que "lhe derrama pelos membros as funções vitais". Heinz Mohnhaupt ensina que:

“o elemento do 'estado' nos conceitos de 'constituição' e 'verfassung' remetem à área médica. A 'verssung' médica do ser humano e a 'constituição' do seu corpo referem-se ainda hoje ao estado condicionado pela ação conjunta das forças físicas e psíquicas no organismo humano. Precisamente da comparação do corpo humano e do organismo estatal a concepção organológica do Estado extrai as suas imagens linguísticas"36.

É precisamente este o uso praticado pelos revolucionários do Porto nos alvores do constitucionalismo no continente.

O Manifesto critica ainda a forma antiga de convocação das Cortes, sujeita à exclusiva vontade do chefe que as presidia, bem como sua composição, em que nem a

\footnotetext{
${ }^{33}$ Manifesto. In: Clemente dos Santos (org.). Documentos para a História das Cortes Gerais da Nação Portuguesa. (vol. 1), Porto, p. 80-83.

${ }^{34}$ Ib idem, p. 80-83.

${ }^{35} \mathrm{Ib}$ idem, p. 80-83.

${ }^{36}$ MOHNHAUPT, Heinz; GRIMM, Dieter. Constituição - História do conceito desde a antiguidade até os nossos dias. Belo Horizonte: Livraria Tempus, 2012, p. 13.
} 
nobreza, nem o clero, nem a "massa total" do terceiro estado ${ }^{37}$ elegiam seus representantes e os "três corpos separados em suas deliberações ofereciam aos olhos o mui expressivo emblema da parcialidade de interesses que os parcelava em frações"38. Finalmente, criticava a total falta de independência das Cortes antigas, razão pela qual sustenta que eram um "simulacro" de Cortes, antiquada forma do feudalismo.

Neste passo, expede as Instruções para eleições, "pela primeira vez no largo decurso dos séculos", dos deputados que irão tomar assento nas Cortes, que deveriam ser aplicadas a Portugal, às ilhas adjacentes, ao Brasil e aos domínios ultramarinos, concitando os "irmãos ultramarinos" a colaborar com a "regeneração imortal do império lusitano", como "concidadãos", extinguindo-se, para sempre, o injurioso apelido de “colônias". Vale destacar o pedido de circunspecção aos eleitores para a eleição dos "patriarcas da nação, os fundadores da pátria", que haveriam de construir "os alicerces do Estado"39.

Ao longo do mês de novembro, as Instruções expedidas suscitaram reclamações dos militares e do povo de Lisboa, causando uma divisão interna nas Juntas Provisionais e chegando a estabelecer-se um princípio de crise militar, que, no entanto, foi debelada com a consolidação de algumas alterações à proposta original. Assim é que em 22 de novembro de 1820 foram publicadas novas Instruções, regulando a eleição dos compromissários, eleitores e deputados das Cortes Extraordinárias, dividida em duas partes: a primeira, contendo uma tradução literal da Constituição espanhola e a segunda, com as adaptações às particularidades portuguesas. As novas Instruções designaram o

\footnotetext{
${ }^{37}$ SIEYÈS, Emannuel. A Constituinte Burguesa - O que é o Terceiro Estado? Org. e Int. Aurélio Wander Bastos. Trad. Norma Azeredo. 4a. edição. Rio de Janeiro: Lumen Júris, 2001.

${ }^{38}$ Manifesto. In: Clemente dos Santos (org.). Documentos para a História das Cortes Gerais da Nação Portuguesa. (vol. 1), Porto, p. 80-83.

${ }^{39}$ Para todas as expressões em destaque, ver Manifesto. In: Clemente dos Santos (org.). Documentos para a História das Cortes Gerais da Nação Portuguesa. (vol. 1), Porto, p. 80-83.
} 
dia 06 de janeiro de 1821 para a reunião, em Lisboa, dos deputados eleitos para as Cortes.

Assim, as referidas Instruções começam por definir a natureza das Cortes, que “são a reunião de todos os deputados que representam a nação, nomeados pelos cidadãos" $^{40}$ na forma estabelecida. Dispunha ainda que a base da representação nacional seria a mesma em ambos os hemisférios, composta por indivíduos oriundos dos domínios portugueses, que obtiverem o título de cidadão, compreendidos os filhos legítimos de estrangeiros domiciliados em Portugal que, tendo nascido nos domínios portugueses, nunca os tenha deixado sem licença do governo e que fixarem domicílio em qualquer povoação dos referidos domínios, exigindo-se para estes, ainda, a idade de vinte e um anos completos e o exercício de emprego, ofício ou ocupação útil. As Instruções estabelecem um critério proporcional para as eleições, segundo o número de habitantes nas povoações, prescrevendo que para cada trinta mil pessoas haveria um deputado, de modo que o número de deputados não fosse inferior a cem. Para a eleição dos deputados às Cortes deveriam se formar Juntas Eleitorais de Freguesias, Comarcas e Províncias.

Em apertada síntese, as Juntas Eleitorais escolhiam os eleitores das Comarcas, que, por sua vez, elegiam os eleitores das Províncias, que, finalmente, se congregariam na capital para a eleição e nomeação dos deputados que iriam assistir às Cortes como representantes da nação.

Vale destacar que a Constituição espanhola exigia a comprovação de determinada renda como condição de elegibilidade aos deputados das Cortes, mas as Instruções portuguesas não repetiram essa determinação, de modo que se pode concluir que, em Portugal, o voto não foi censitário na eleição dos deputados às Cortes Gerais e

\footnotetext{
${ }^{40}$ Ver artigo 27 das Instruções, in: Clemente dos Santos (org.). Documentos para a História das Cortes Gerais da Nação Portuguesa. (vol. 1), Porto, p. 108-116.
} 
Extraordinárias. Foi vedada a eleição para deputado das Cortes aos conselheiros de estado, a todas as pessoas ocupantes de empregos da casa real e aos estrangeiros. As Instruções dispuseram ainda que nenhum funcionário público poderia ser eleito deputado das Cortes pela Província em que exercer suas funções ${ }^{41}$.

Imediatamente após a eleição dos deputados das Cortes, os eleitores lhes outorgariam uma procuração com poderes específicos para "proceder à organização da constituição política desta monarquia, mantida a religião católica apostólica romana e a dinastia da sereníssima casa de Bragança, tomando por bases fundamentais as da Constituição da monarquia espanhola"42. Foram eleitos 100 deputados pelo continente do reino de Portugal, 09 pelas ilhas adjacentes, 07 pelas possessões da Ásia e África e 65 pelo Brasil, totalizando 181 deputados das Cortes Gerais e Extraordinárias ${ }^{43}$.

Regulada definitivamente a forma das eleições e restabelecida a ordem pública, a Junta Provisional do Governo Supremo do Reino expediu, em 15 de dezembro de 1820, um Manifesto da nação portuguesa aos soberanos e povos da Europa, inventariando as causas do flagelo português que deflagraram a revolução no Porto, posteriormente estendida a Lisboa e que culminou, enfim, com a determinação da realização de eleições para a escolha dos representantes da nação, que deveriam reunirse em Cortes Gerais e Extraordinárias em 06 de janeiro de 1821 para iniciar os trabalhos de elaboração da Constituição Portuguesa. A instalação do Congresso ocorreu a 26 de janeiro, mesmo sem a representação ultramarina, o que, inclui, por óbvio, o Brasil, onde as eleições só terminariam em 1822.

\footnotetext{
${ }^{41}$ Cf. Constituição Política da Monarquia Hespanhola, promulgada em Cadiz em 19 de março de 1812, traduzida em português por A.M.F. Coimbra: Real Imprensa da Universidade, 1820. Cf. ainda Constituição Política da Monarquia Portuguesa. Transcrição feita de acordo com o original, actualizando a grafia (Luís Filipe Correia Henriques). Lisboa: Chancelaria-mor da Corte e Reino, 1822.

${ }_{2}^{42}$ Conferir o inteiro teor da "procuração" em Instruções, in: Clemente dos Santos (org.). Documentos para a História das Cortes Gerais da Nação Portuguesa. (vol. 1), Porto, p. 108-116.

${ }^{43}$ Clemente dos Santos (org.). Documentos para a História das Cortes Gerais da Nação Portuguesa. (vol. 1), Porto, p. 130.
} 
Os acontecimentos em Portugal, notadamente a convocação das Cortes por meio de um complexo sistema eleitoral, repercutiram no Brasil e, já no início de 1821, periódicos brasileiros divulgavam estes fatos, como a "Idade d'Ouro do Brasil", periódico da Bahia, que, na edição 24, de 27 de fevereiro de 1821, apresentava as Cortes como uma "representação nacional, pela qual só se pode regular invariavelmente os destinos do povo e fixar para sempre a constância da sua felicidade" ${ }^{\text {, }}$. Por sua vez, o "Diálogo instrutivo em que se explicam os fundamentos de uma Constituição" aduzia que as Cortes constituíam um instrumento da vontade nacional, que se expressava livremente para formar a Constituição, “onde todo o cidadão deve depositar uma parte de sua liberdade para garantir ou afiançar os seus direitos individuais" ${ }^{45}$. O movimento constitucional iniciado no Porto, expandido para as Províncias do Norte e do Sul e definitivamente selado em Lisboa, atravessava o Atlântico e aportava no Brasil.

O maior desenvolvimento do transporte marítimo e as dificuldades de transporte terrestre à época, somados às grandes distâncias entre as Províncias no Brasil, tornavam, aparentemente, as Províncias do Norte, como o Pará, o Maranhão, Pernambuco e a Bahia mais próximas de Portugal do que do Rio de Janeiro. Para além dessa proximidade "geográfica", o descontentamento destas Províncias com a política imperial adotada pela Corte Real, de grande favorecimento e centralidade, conferidos ao Rio de Janeiro, em detrimento daquelas que, como Pernambuco, era ainda naquela altura a maior produtora das riquezas brasileiras, favorecia também a proximidade político-ideológica com Portugal, enxergando na Revolução do Porto um caminho para

\footnotetext{
${ }^{44}$ Bahia. Idade d'Ouro do Brasil. n ${ }^{\circ}$ 24, 27 de fevereiro de 1821.

45 Diálogo instrutivo em que se explicam os fundamentos de huma Constituição e a divisão das autoridades que a formão e executão. (Por hum Patriota Amigo da Razão). Rio de Janeiro: Tip. Real, 1821, p. 3.
} 
a sua própria regeneração e a recondução ao lugar de destaque que sempre ocuparam nos negócios do Brasil $^{46}$.

Por isso mesmo é que o Grão-Pará foi a primeira Província a manifestar adesão ao movimento liberal português, formalizado por meio de um ofício enviado à Junta Provisional do Supremo Governo do Reino em 05 de fevereiro de 1821, comunicando seu juramento às Cortes e à Constituição por elas estabelecida, ofício este recebido pelas Cortes na sessão de 27 de março de 1821. No referido ofício se lê que:

\begin{abstract}
"chamados pelo voto livre e espontâneo dos habitantes desta cidade ao Governo Provisional da Capitania, temos a honra de participar a V. Exa. que, no dia $1^{\circ}$ de Janeiro do corrente ano, o povo, as tropas e todas as autoridades constituídas desta Capital, aclamaram e solenemente juraram obediência a El Rey, o senhor D. João VI e à Augusta Casa de Bragança, às Cortes Nacionais e à Constituição que por elas for estabelecida, mantida a religião católica romana" ${ }^{47}$.
\end{abstract}

Por fim, o ofício informa que elegeram uma Junta composta dos subscritores do ofício, incumbidos do Governo Provisório da Capitania até a instalação das Cortes ${ }^{48}$.

A “Idade d'Ouro do Brasil" noticiava em 13 de fevereiro do mesmo ano o juramento, em 10 de fevereiro, da Bahia à Constituição a ser elaborada pelo Congresso $^{49}$. Essa notícia também chegou ao conhecimento do Congresso português por meio de publicação levada a efeito pelo "O Campeão em Londres", na edição do dia 16 de março de 1821. Um mês depois, na sessão do dia 16 de abril, o Ministro Secretário de Estado dos Negócios da Marinha confirma a notícia da adesão baiana, apresentando ao Congresso uma carta-oficio expedida pela Junta Provisional do Governo Provisório da Bahia, onde se lê que:

"vimos por esta expressar ao Soberano Congresso Nacional junto em Cortes, a nossa mais solene e decisiva adesão à sagrada causa da nossa liberdade e

\footnotetext{
${ }^{46}$ MELLO, Evaldo Cabral. A outra Independência: o federalismo pernambucano de 1817 a 1824 . São Paulo: Ed. 34, 2004.

${ }^{47}$ Diario das Cortes Geraes e Extraordiarias da Nação Portugueza, Vol. I, p. 369.

${ }^{48}$ Cf. ainda CARVALHO, Manuel Emílio Gomes de. Os deputados brasileiros nas Cortes gerais de 1821. Brasília, Senado Federal, 1979, p. 13-15.

${ }^{49}$ Bahia. Idade d'Ouro do Brazil. n 13 , de 13 de fevereiro de 1821.
} 
regeneração... declarando em ratificando em nosso nome e em nome do Povo que representamos, que juramos a Constituição que as Cortes decretarem e ainda interinamente a da Monarquia Espanhola, segundo se acha adotada, mantida a Dinastia da Sereníssima Casa de Bragança e a religião dos nossos pais" ${ }^{, 50}$.

Diante dessa notícia, o próprio Ministro da Marinha ficou encarregado de partir num brigue em poucos dias, levando as Bases da Constituição à Bahia e a todos os portos que tinham aderido ao sistema constitucional e também ao Rio de Janeiro, onde esperavam que o rei também jurasse as mesmas Bases.

Na sessão do dia seguinte, 17 de abril de 1821, os comerciantes da Cidade do Porto informavam ao Congresso que haviam recebido a notícia da adesão de Pernambuco ao sistema constitucional adotado em Portugal, conforme proclamavam os tripulantes e passageiros do navio Feliz Ventura, saído daquele porto no dia 7 de março. Segundo eles, após o juramento da Constituição pela Bahia, o Governo Provisório daquela província havia expedido um brigue de guerra para Pernambuco para participarlhe tal adesão, mas chegando lá tiveram ciência que os pernambucanos já haviam deliberado algumas horas antes a adotar o sistema constitucional ${ }^{51}$.

Na sessão do dia 18 de abril, as Cortes aprovaram um decreto, em que reconheciam as Juntas criadas nas capitanias do Grão-Pará e na Bahia e mandavam proceder à eleição dos deputados brasileiros para tomar assento no Congresso Nacional, de acordo com as Instruções de 22 de novembro de 1820. Já na sessão do dia 27 de abril chegava a Lisboa a fragata "Maria da Glória" com a notícia do juramento das Bases Constitucionais e da futura Constituição por D. João VI ${ }^{52}$.

As notícias do sucesso da revolução em Portugal acenderam no Brasil uma viva polêmica em torno da permanência ou não da Corte Real no Rio de Janeiro e sobre o

\footnotetext{
${ }^{50}$ Diario das Cortes Geraes e Extraordiarias da Nação Portugueza, Vol. I, p. 600.

${ }^{51}$ Ib idem, p. 609.

52 CARVALHO, Manuel Emílio Gomes de. Os deputados brasileiros nas Cortes gerais de 1821. Brasília, Senado Federal, 1979, p. 19-20.
} 
futuro da monarquia e do Reino de Portugal, Brasil e Algarves ${ }^{53}$. Subjacente a essa polêmica, gravitava a questão constitucional como garantia de permanência da monarquia e preservação do poder real da Dinastia de Bragança e a possibilidade de ruptura e o início de um novo tempo, o do governo dos homens e não dos reis.

Com efeito, no dia 14 de janeiro de 1821, Thomaz Antônio de Villanova Portugal escrevia a D. João VI apresentando à Sua Majestade o "papel de Cailhe", que segundo ele, merecia ser impresso. No mesmo dia, o rei responde a ele, autorizando a impressão, já que Villanova a havia julgado uma boa obra ${ }^{54}$. Na verdade era mais do que isso. A obra refletia as posições do próprio ministro Thomaz Antônio de Villanova Portugal, sintetizadas em seis proposições: 1) nas circunstâncias daquele momento, Portugal dependia muito mais do Brasil do que o inverso; 2) a partida da família real para a Europa representaria o prelúdio da independência do Brasil; 3) permanecendo no Brasil, Sua Majestade poderia fundar um florescente império entre os maiores do mundo; 4) o fervor revolucionário dos portugueses da Europa se dissolveria naturalmente ante a determinação do rei de não poder deixar o Brasil, o contrário ocorrendo caso ele resolvesse se mudar para Lisboa; 5) nada de falar em constituição, e; 6) sempre haveria a possibilidade do rei voltar atrás à tempo de tomar as medidas que ele julgasse necessárias ${ }^{55}$.

\footnotetext{
${ }^{53}$ Cf. a respeito o impresso intitulado "Le Roi et la Famille Royale de Bragance doivent-ils, dans les circonstances presentes, retourner em Portugal, ou bien rester au Brèsil?" cuja autoria é atribuída à Caille de Geine, bem como o impresso intitulado "Exame analítico-crítico da solução da questão: o Rei, e a Família Real de Bragança devem, nas circunstâncias presentes, voltar a Portugal ou ficar no Brasil?", publicada em resposta ao folheto anterior, sem data e autor. In Documentos para a história da independência. Rio de Janeiro, Oficinas Gráficas da Biblioteca Nacional, 1923, vol. 1, p. 201-215.

${ }^{54} \mathrm{Cf}$. as cartas autógrafas trocadas entre o rei D. João VI (assinadas J.C.) e Thomaz Antônio de Villanova Portugal no dia 14 de janeiro, publicadas em Documentos para a história da independência. Rio de Janeiro, Oficinas Gráficas da Biblioteca Nacional, 1923, vol. 1, p. 180-181.

${ }^{55}$ Cf. impresso intitulado "Le Roi et la Famille Royale de Bragance doivent-ils, dans les circonstances presentes, retourner em Portugal, ou bien rester au Brèsil?", cuja autoria é atribuída à Caille de Geine, publicada em Documentos para a história da independência. Rio de Janeiro, Oficinas Gráficas da Biblioteca Nacional, 1923, vol. 1, p. 201-208.
} 
O opúsculo acima referido repercutiu nos círculos diplomáticos, tanto no Brasil como internacionalmente, merecendo análise e refutação por parte do Correio Braziliense e nos comentários à tradução portuguesa, intitulados "Exame analíticocrítico da solução da questão: o Rei e a Família Real de Bragança devem, nas circunstâncias presentes, voltar a Portugal ou ficar no Brasil?” impresso na Tipografia da Viúva Serva e Carvalho, sem menção de data e autor ${ }^{56}$. Em síntese, o impresso refutava uma a uma as proposições acima referidas, reafirmando a união de Brasil e Portugal por meio da sua Constituição, pois “o rei constitucional não deixa de ser rei em toda a sua extensão da sua ideia, só porque usa da sua autoridade conjuntamente com as Cortes ${ }^{57}$. O folheto assevera ser irracional o conselho dado à Sua Majestade de abandonar Portugal, sob a justificativa de que só no Brasil sem constituição o rei conservaria inteira a sua autoridade, isto porque a constituição "não ofende a Majestade, regula somente o uso do seu poder" ${ }^{\text {"58 }}$. E justamente a constituição é que representaria a “segurança de estabilidade" da constituição do Brasil como Império, partindo o rei para Portugal ou não.

A referida polêmica antagonizou dois importantes personagens do processo de independência do Brasil: o Conde de Palmella e Thomaz Antônio de Vilanova Portugal. O primeiro, um "liberal conservador", adepto de uma "opção europeia" nas mudanças constitucionais, que defendia o retorno de algum representante da família real a Portugal, como forma de assegurar a continuidade da monarquia e do império lusobrasileiro. O segundo, absolutista, adepto de uma "opção americana", que sustentava a rígida manutenção da estrutura administrativa, acreditando na contrarrevolução e na

\footnotetext{
${ }^{56}$ Documentos para a história da independência. Rio de Janeiro, Oficinas Gráficas da Biblioteca Nacional, 1923, vol. 1, p. 208-215.

${ }^{57}$ Cf. impresso intitulado "Exame analítico-crítico da solução da questão: o Rei, e a Família Real de Bragança devem, nas circunstâncias presentes, voltar a Portugal ou ficar no Brasil?". In Documentos para a história da independência. Rio de Janeiro, Oficinas Gráficas da Biblioteca Nacional, 1923, vol. 1, p. 208-215.

${ }^{58}$ Ib idem, p. 212.
} 
Santa Aliança, defendendo, ao revés, a permanência de D. João VI no Brasil (posteriormente admitiu a partida de D. Pedro para Portugal). Em caso extremo, Thomaz Antônio de Villanova Portugal não via problema na desintegração do império luso-brasileiro, desde que o monarca preservasse íntegro o Reino do Brasil, para ele a parte mais importante do império.

Desde meados de 1820, vinha prevalecendo na corte real a linha política implementada por Thomaz Antônio de Vilanova Portugal, sustentando que as Cortes convocadas pelos Governadores do Reino eram ilegais, sendo necessário ao Rei D. João VI autorizá-las com funções meramente consultivas ${ }^{59}$. Vale destacar a defasagem entre os acontecimentos em Portugal e o recebimento das notícias no Brasil, o que fazia com que as respostas emitidas pela corte real ficassem desconectadas com a atualidade do movimento revolucionário. Por isso mesmo é que, enquanto em meados de outubro Vilanova Portugal referia-se às Cortes convocadas pelos Governadores do Reino, em Portugal os Governadores já haviam sido depostos pelos militares em Lisboa e, inclusive, já estava em curso a elaboração das instruções para eleições dos representantes da nação que deveriam reunir-se em Cortes Gerais e Extraordinárias, como mencionado linhas acima.

Essa defasagem faz parecer, inclusive, que o Rei estaria completamente alheio ao estado de coisas que se passavam em Portugal, contribuindo, sem dúvida nenhuma, para o desenrolar do movimento revolucionário. Com efeito, a análise de alguns documentos inseridos por Clemente dos Santos, na sua coletânea de "Documentos para a História das Cortes Gerais da Nação Portuguesa", permite concluir que as notícias levavam, em média, de sessenta a noventa dias para cruzar o Atlântico. É emblemático,

\footnotetext{
${ }^{59}$ Cf. as cinquenta cartas autógrafas trocadas entre o rei D. João VI e Thomaz Antônio de Villanova Portugal entre os dias 17 de outubro de 1820, quando chegaram ao Rio as primeiras notícias do movimento constitucional português e 24 de fevereiro de 1821, dois dias antes da queda do ministério, publicadas em Documentos para a história da independência. Rio de Janeiro, Oficinas Gráficas da Biblioteca Nacional, 1923, vol. 1, p. 173-197.
} 
por exemplo, que D. João VI tenha enviado, pelas mãos do Marechal Beresford, uma importante carta patente em 29 de julho de 1820, desde o Rio de Janeiro, com instruções para a brigada militar, mas que tal carta só tenha chegado a Lisboa em 10 de outubro do mesmo ano, quando fundeara no porto daquela cidade a nau inglesa "Vengeur", ocasião em que o movimento revolucionário já havia estourado no Porto e em Lisboa, tendo, inclusive, a Junta Provisional do Governo Supremo do Reino impedido o desembarque do Marechal Beresford, figura que simbolizava o jugo inglês, contra o qual os revolucionários também se insurgiam ${ }^{60}$.

Neste passo, as notícias do levante militar no Porto, de 24 de agosto, somente teriam chegado ao conhecimento da corte real no Rio de Janeiro em 17 de outubro, por meio das cartas enviadas pelos então Governadores do Reino à Sua Majestade, em que informavam a convocação das Cortes. Isto rendeu ensejo às consultas formuladas por D. João VI aos seus ministros e outras personalidades, sobre o modo de agir em decorrência daquelas notícias e, em consequência, à opinião manifestada por Thomaz Antônio Vilanova Portugal de que, diante daquelas notícias, melhor seria que o Rei referendasse a convocação das Cortes - ainda que expressamente declarando a ilegalidade de sua convocação - com funções meramente consultivas. Poucos dias depois - a 12 de novembro - novo e maior sobressalto sacudia a corte no Rio de Janeiro com a chegada das notícias sobre a adesão de Lisboa em 15 de setembro e a deposição dos Governadores do Reino ${ }^{61}$.

Desembarca no Rio de Janeiro, no dia 20 dezembro, o Conde de Palmella, trazendo notícias frescas sobre a amplitude e alcance do movimento revolucionário

\footnotetext{
${ }^{60}$ Ver a Carta Patente enviada por D. João VI, bem como as datas da remessa e recebimento da aludida carta e ainda a expulsão do Marechal Beresford em Clemente dos Santos (org.). Documentos para a História das Cortes Gerais da Nação Portuguesa. (vol. 1), p. 77-78. Para mais informações sobre o papel de Beresford no jugo inglês a Portugal, ver ALEXANDRE, Valentim. Os sentidos do Império - Questão Nacional e Questão Colonial na Crise do Antigo Regime Português. Edições Afrontamento, Porto, 1993, p. 171.

${ }^{61}$ ALEXANDRE, Valentim. Os sentidos do Império - Questão Nacional e Questão Colonial na Crise do Antigo Regime Português. Edições Afrontamento, Porto, 1993, p. 496.
} 
português, de que era testemunha ocular, causando um "choque elétrico"62 na corte real e na política que seria adotada dali em diante. Palmella baseia-se em três pontos fundamentais: a) desmistifica a dimensão circunstancial e limitada da revolução constitucional, que tinha prevalecido até então na política de Vilanova Portugal, procurando demonstrar a D. João que o movimento liberal português constituía uma vaga de maior profundidade, reflexo de um novo ambiente espalhado por toda a Europa; b) para conservar o Reino do Brasil havia de primeiro conservar o Reino de Portugal, resgatando uma visão luso-brasileira de um império, cujo centro de poder estaria situado na Europa; c) a necessidade de pôr termo à revolução em Portugal, a fim de evitar o seu espraiamento ao Brasil.

Valendo-se desta análise, Palmella propunha como solução, em primeiro lugar, que o Rei declarasse aos portugueses do Brasil e da Europa sua intenção de governar sob um regime constitucional, estabelecido sob as bases por ele mesmo indicadas; em segundo lugar, a partida do príncipe para Lisboa para presidir as Cortes e sancionar, em nome do Rei, a Constituição a ser elaborada segundo as bases por ele já ditadas; e, em terceiro lugar, a nomeação pelo Rei de alguns representantes das Províncias para consultas sobre as circunstâncias locais, assegurando alguma representatividade no Brasil.

Em 27 de janeiro de 1821, Palmella apresentou a D. João VI um "Projeto de Manifesto"63, no qual indicava os artigos que serviriam de base à constituição da Monarquia, consagrando a separação dos poderes do Estado, concebendo o Poder Executivo "indiviso e inviolável” à pessoa do Rei; o legislativo, "com a faculdade de

\footnotetext{
${ }^{62}$ A expressão é de Valentim Alexandre, ob. cit., p. 497, reproduzida por Lúcia Maria Bastos Pereira das Neves in Corcundas e constitucionais: a cultura política da independência (1820-1822). Rio de Janeiro: REVAN: FAPERJ, 2003, p. 242.

${ }^{63}$ As citações foram retiradas do Ofício de 27 de janeiro de 1821, in Reis e Vasconcelos, Despachos $e$ Correspondências, vol. I, p. 163-164, apud ALEXANDRE, Valentim. Os sentidos do Império - Questão Nacional e Questão Colonial na Crise do Antigo Regime Português. Edições Afrontamento, Porto, 1993, p. 499.
} 
impor tributos", seria "exercido coletivamente por El-Rei e pelas Cortes" (o que deixava em aberto se o monarca gozaria de veto absoluto ou apenas de veto suspensivo), “reunindo-se em uma só Câmara os dois braços do Clero e Nobreza e em outra os Representantes da Nação"; e o judicial caberia a "Tribunais independentes e inamovíveis". O projeto estabelecia ainda a garantia de direitos fundamentais, aduzindo que:

\footnotetext{
"a liberdade individual, a segurança de propriedade, a liberdade moderada da imprensa, a igualdade de todos os portugueses perante os tribunais e a igualdade da repartição dos impostos, sem distinção de privilégios, nem de classes, serão garantidas e asseguradas pelas leis fundamentais da Monarquia".
}

Finalmente, as bases ainda dispunham sobre a sede da monarquia, alternativamente em Portugal e no Brasil, conforme as circunstâncias assim o exigissem.

O projeto apresentado por Palmella se reveste de enorme importância naquele contexto, pois, não obstante a preservação de certa superioridade do Monarca na arquitetura do Estado após a revolução liberal no Porto, representa uma análise muito apropriada do momento histórico vivido na Europa, no que tange à sedimentação de um ideário constitucionalista, rompendo, assim, uma lógica absolutista, que não enxergava limites à ação do Monarca e passando a prever uma separação de poderes e garantias e direitos fundamentais do cidadão em face do Estado. Convém destacar, no entanto, que os laços pessoais de Palmella estavam atados a Portugal, de modo que, ainda que suas ideias fossem liberais, o Brasil não representava o cerne de suas preocupações, salvo no tocante à própria preservação do império lusitano. Por outro lado, Palmella justificava seu projeto por razões táticas. Para ele, ao prometer a formação de um governo constitucional e outorgar as bases sobre as quais ele deveria ser constituído, D. João VI não faria mais do que "antecipar espontaneamente uma concessão, que dentro em pouco 
tempo se veria obrigado pelas circunstâncias a tolerar" ${ }^{\prime 64}$ e preveniria a alternativa de escolher entre "aceitar uma Constituição semelhante à da Espanha ou abandonar a Coroa de Portugal" ${ }^{\prime 65}$. Cumpre sublinhar, igualmente, que, antes de embarcar para o Rio de Janeiro, Palmella esteve em contato com a ala mais moderada dos liberais da Revolução em Portugal, e tentava construir uma solução de compromisso entre os revolucionários e a Corte no Rio de Janeiro ${ }^{66}$.

O fato é que Thomaz Antônio Vilanova Portugal opunha-se ferrenhamente à outorga das bases da constituição (ponto essencial para Palmella, em relação ao qual se mantinha irredutível) bem como ao envio de alguém da família real para Portugal naquele momento, "para que quando passar a vertigem (da revolução) o achem Rei e não Presidente ${ }^{, 67}$, mas acaba por ceder às pressões e assente com a partida do Príncipe Real para Lisboa para "ouvir, saber as queixas, remediar o que for segundo as Leis e propor a Vossa Majestade as emendas ou reformas", mas "nada de falar de Constituição"! ${ }^{68}$ As notícias da adesão da Bahia em 10 de fevereiro aceleram o passo das tomadas de decisão e, em 18 de fevereiro, Thomaz Antônio elabora um projeto de decreto cedendo em dois pontos importantes: admitindo que D. Pedro I, uma vez em Portugal, transmitisse ao Rei a Constituição para sua "aprovação final" (querendo com

\footnotetext{
${ }^{64}$ Ofício de 5 de janeiro de 1821, in Reis e Vasconcelos, Despachos e Correspondências, vol. I, p. 145, apud ALEXANDRE, Valentim. Os sentidos do Império - Questão Nacional e Questão Colonial na Crise do Antigo Regime Português. Edições Afrontamento, Porto, 1993, p. 500.

${ }^{65}$ Ofício de 16 de janeiro de 1821, in Reis e Vasconcelos, Despachos e Correspondências, vol. I, p. 150, apud ALEXANDRE, Valentim. Os sentidos do Império - Questão Nacional e Questão Colonial na Crise do Antigo Regime Português. Edições Afrontamento, Porto, 1993, p. 500.

${ }^{66}$ Valentim Alexandre, op. cit., p. 476, nos revela que o próprio Palmella confirmou, em pronunciamento feito quinze anos mais tarde, em sessão da Câmara dos Deputados do dia 17 de março de 1835, a reunião com líderes revolucionários em Lisboa, entre eles o Fr. Francisco de São Luís, Lobo de Moura e o Coronel Sepúlveda, visando à construção de uma solução amigável para a crise do antigo regime. Vale a pena destacar um trecho do discurso de Palmella na referida sessão parlamentar: "Tive porém, naquela época, conferências confidenciais e francas com um dos mais conspícuos membros do governo provisório, o sr. D. Fr. Francisco de S. Luís; encarreguei-me de uma carta dele para o senhor D. João $V I$, e dei-lhe a minha palavra (que cumpri) de aconselhar a sua majestade que se antecipasse a promulgar pelo menos as bases de uma constituição liberal e monárquica".

${ }^{67}$ Ofícios de 16 e 17 de janeiro de 1821, in Ângelo Pereira, D. João VI Príncipe e Rei, Vol. III - A Independência do Brasil, citados na nota 182, p. 321-323 apud ALEXANDRE, Valentim. Op. cit. p. 503.

${ }^{68}$ Documentos para a história da independência. Rio de Janeiro, Oficinas Gráficas da Biblioteca Nacional, 1923, vol. 1, p. 184.
} 
isso dizer, para a sua "sanção" ou "veto"), bem como aceitando a convocação de uma junta representativa para o Brasil, com função meramente consultiva sobre a adaptação da Constituição elaborada em Portugal.

O mês de fevereiro do ano de 1821 é determinante para a história constitucional brasileira, sendo marcado pela adesão da Bahia ao movimento constitucional iniciado na cidade do Porto, bem como pelo acirramento das discórdias entre Palmella e Thomaz Antônio de Vilanova Portugal. Em contraposição ao projeto de Villanova Portugal, Palmella apresenta, no dia 23 de fevereiro, outro projeto de decreto, muito assemelhado com o "projeto de manifesto" acima citado e nele o referido ministro propõe ao rei o estabelecimento das bases em que deveria ser elaborada a Carta Constitucional de Portugal, que seriam proclamadas por D. Pedro em nome do rei:

“1”. O Poder Executivo residirá indiviso e inviolável na pessoa do rei. $2^{\circ}$. O Poder Legislativo será exercido coletivamente pelo rei e pelas Cortes divididas em duas câmaras. $3^{\circ}$. O Poder Judicial será administrado publicamente por Tribunais independentes e inamovíveis em nome do rei. $4^{\circ}$. A liberdade individual, a segurança da propriedade e a liberdade moderada de imprensa; a igualdade de todos os portugueses perante os Tribunais; a igualdade da repartição dos impostos sem distinção de privilégios, nem de classes; a responsabilidade dos ministros e dos empregados do governo; a publicidade da administração das rendas do Estado, serão garantidas e asseguradas pelas leis da monarquia"69.

O projeto ainda consignava que sobre estas bases seria "reformada" em Cortes a “Constituição da monarquia”, a qual seria transmitida a D. João por D. Pedro, a fím de receber a sanção real. Além disso, considerando as diferenças entre Portugal, Brasil e as demais ilhas e domínios ultramarinos, o rei mandaria convocar no Rio de Janeiro uma Junta de Cortes, composta por procuradores nomeados pelas câmaras das Cidades e Villas principais do Reino do Brasil, assim como das Ilhas da Madeira, Açores e Cabo Verde, para propor as adaptações necessárias a uma boa aplicação das referidas bases constitucionais a eles. Consta ainda uma relação das pessoas nomeadas para a comissão

\footnotetext{
${ }^{69}$ Projeto de Decreto in Documentos para a história da independência. Rio de Janeiro, Oficinas Gráficas da Biblioteca Nacional, 1923, vol. 1, p. 218-220.
} 
da Junta de Cortes, dentre os quais alguns futuros constituintes, como o Barão de Santo Amaro, Luiz José de Carvalho e Mello, Antônio Rodrigues Vellozo de Oliveira, João Severiano Maciel da Costa, José da Silva Lisboa, Antônio Luiz Pereira da Cunha e Manoel Jacinto Nogueira da Gama.

A disputa entre Villanova Portugal e Palmella representava não apenas um dissídio individual entre os dois importantes ministros do Reino, mas sim uma visão antagônica sobre o problema do constitucionalismo e as suas consequências para a monarquia bragantina em Portugal e no Brasil. As divergências entre eles retratam muito bem como as diferenças de sentido da constituição podiam ser mobilizadas em prol de projetos tão distintos. Villanova enxergava na constituição um perigo para a monarquia, ainda que à custa de uma separação de Portugal. Palmella, ao contrário, vislumbrava a constituição como garantia de estabilidade da monarquia, condição necessária para manutenção do Reino Unido.

O fato é que Villanova Portugal acaba por convencer D. João VI a assinar o projeto de decreto por ele elaborado, publicado no dia 23 de fevereiro, motivando o pedido de demissão de Palmella $^{70}$ e precipitando a distensão máxima das clivagens na capital. Em sua carta de demissão, Palmella adverte que as concessões que já havia feito em seu projeto de decreto talvez teriam sido suficientes para evitar uma comoção no Rio de Janeiro, já que a tropa portuguesa esperava uma definição do rei quanto ao juramento das bases constitucionais elaboradas pelas Cortes de Lisboa.

Na madrugada do dia 26 de fevereiro, a Divisão Portuguesa do exército reuniuse na Praça do Rossio, atual Praça da Constituição, exigindo o juramento imediato do Rei às bases da futura Constituição portuguesa, a demissão dos membros do governo e,

\footnotetext{
${ }^{70}$ Carta com pedido de demissão de Palmella in Documentos para a história da independência. Rio de Janeiro, Oficinas Gráficas da Biblioteca Nacional, 1923, vol. 1, p. 220-221.
} 
finalmente, a adoção da Constituição espanhola de Cádiz, enquanto não se ultimassem os trabalhos das Cortes de Lisboa ${ }^{71}$.

A participação de D. Pedro I nestes movimentos constitucionais levados a efeito em fevereiro de 1821 é ambígua. Em primeiro lugar, merece destaque uma carta dirigida ao pai, o Rei D. João VI, sem data, mas aparentemente escrita em 22 de fevereiro $^{72}$, em que se posiciona contrariamente às posições defendidas pelo Conde de Palmella, aduzindo que:

\begin{abstract}
"lei nenhuma terá vigor sem ser proposta pelo Rei em Cortes, as quais devem ser consultivas, quero dizer, terem o direito de discutirem a proposta Real, a qual, depois de decidida pela pluralidade de votos, será sancionada pelo Rei. Mandar as bases da Constituição é reconhecer a convocação destas cortes (...) e é indecoroso a Vossa Majestade" ${ }^{\text {, }}$.
\end{abstract}

Por outro lado, D. Pedro comparece ao Rossio na madrugada do dia 26 de fevereiro para negociar com a tropa e aceitar, em nome do Rei, as exigências dos revoltosos, inclusive o juramento da Constituição feita pelas Cortes de Lisboa, segundo as bases por elas estabelecidas ${ }^{74}$.

Existem notícias de que D. Pedro I teria se reunido anteriormente com a tropa revoltosa da Divisão Portuguesa ${ }^{75}$, o que torna ainda mais ambígua a sua participação

\footnotetext{
${ }^{71}$ Para uma análise detalhada dos acontecimentos do dia 26 de fevereiro, inclusive com a composição das tropas portuguesas que se reuniram na Praça do Rossio, ver "Revolução de 26 de fevereiro de 1821 no Rio de Janeiro" in MORAES, Alexandre José de Mello. História do Brasil-Reino e do Brasil-Império. t. 1. São Paulo: Ed. Universidade de São Paulo, 1982, p. 136-147.

${ }^{72}$ Valentim Alexandre sustenta que a carta foi escrita por D. Pedro em 22 de fevereiro em razão de um ofício enviado por Palmella ao Rei D. João VI no referido dia 22 de fevereiro, em que refuta os termos da carta enviada pelo Príncipe Real. Cf. ALEXANDRE, Valentim. Os sentidos do Império - Questão Nacional e Questão Colonial na Crise do Antigo Regime Português. Edições Afrontamento, Porto, 1993, p. 526.

${ }^{73}$ A redação ipsis literis da carta contém alguns erros de português, como a duplicidade de expressões, razão pela qual fiz as devidas correções para seu melhor entendimento. Para a versão original cf. Documentos para a história da independência. Rio de Janeiro, Oficinas Gráficas da Biblioteca Nacional, 1923, vol. 1, p. 189.

${ }^{74}$ Cf. "Juramento da Constituição no dia 26 de fevereiro de 1821 por um movimento revolucionário no Rio de Janeiro", in MORAES, Alexandre José de Mello. História do Brasil-Reino e do Brasil-Império. t. 1. São Paulo: Ed. Universidade de São Paulo, 1982, p. 60-62.

${ }^{75}$ Tanto Valentim Alexandre, op. cit., p. 530, quanto Lúcia Maria Bastos Pereira das Neves, op. cit., p. 249, citam Maria Beatriz Nizza da Silva como a autora da descoberta da aludida fonte, provavelmente, a "Relação dos sucessos do dia 26 de fevereiro de 1821 na Corte do Rio de Janeiro", arquivada na BNL. SR. MSs. Códice 10759. Por outro lado, no opúsculo "Revolução de 26 de fevereiro de 1821 no Rio de Janeiro", Mello Moraes transcreve um "um documento que se divulgou em 10 de junho de 1822", sem
} 
nestes eventos que marcam o início do constitucionalismo no Brasil. O fato é que o processo de independência já havia começado.

\subsection{BRASIL: NO CAMINHO PARA A ASSEMBLEIA CONSTITUINTE}

O regresso de D. João VI a Portugal, o agravamento do conflito entre as tendências centralizadoras de Lisboa e as aspirações de independência dos brasileiros, que exigiam uma representação paritária a de Portugal nas Cortes Constitucionais, acompanhados da recusa do Príncipe Regente D. Pedro de voltar para a Europa, contrariando as determinações daquelas Cortes, jogavam pimenta no caldo de cultura dos movimentos constitucionais deflagrados na Bahia e no Rio de Janeiro e alimentavam o espírito do separatismo do Brasil em relação a Portugal.

Com efeito, em 29 de setembro de 1821, as Cortes Gerais e Extraordinárias da Nação Portuguesa aprovaram os Decretos 124 e 125, tornados Lei por D. João VI em 01 de outubro do mesmo ano, determinantes para o desfecho da cisão entre Portugal e Brasil, com influência direta no constitucionalismo de ambos os países, mas, principalmente, criando as condições necessárias para a deflagração do processo constituinte no Brasil.

Pelo Decreto 124, as Cortes dispunham sobre o estabelecimento das juntas provisórias e os governos das armas nas províncias do Brasil, o que desagradou os representantes de algumas províncias, especialmente São Paulo e Rio de Janeiro, que perceberam uma intromissão direta, por via legislativa, nos assuntos de governação do

citar a aludida fonte, em que descreve o encontro de D. Pedro com um representante da tropa portuguesa, antes do seu amotinamento na Praça do Rossio. Com efeito, informa que o Padre Francisco Romão de Góis foi até a Real Quinta da Boa Vista prevenir D. Pedro sobre a intenção da tropa, a pedido do comando, a fim de "precaver que a Sereníssima Princesa Real...pelo seu estado de gravidez...tivesse o menor incômodo ou susto, quando soubesse do repentino movimento das tropas" in MORAES, Alexandre José de Mello. História do Brasil-Reino e do Brasil-Império. t. 1. São Paulo: Ed. Universidade de São Paulo, 1982, p. 136-147. O referido documento citado por Mello Moraes pode ser o mesmo localizado por Maria Beatriz Nizza na BNL, mas não pude conferir essa informação. 
Brasil. Por sua vez, pelo Decreto 125, em razão justamente do estabelecimento das juntas provisórias, as Cortes participavam ao Rei sua resolução de que o Príncipe Real deveria regressar o quanto antes para Portugal e tão logo chegasse, deveria viajar para as cortes e reinos de Espanha, França e Inglaterra, acompanhado por pessoas de luzes, virtudes e adesão ao sistema constitucional, a fim de obter os conhecimentos necessários para ocupar dignamente o trono português.

Os Decretos mencionados representaram um ponto de inflexão nas relações entre Portugal e Brasil, reforçando ainda mais a pecha de despotismo das Cortes de Lisboa em relação à ex-colônia, o que motivou uma união das Províncias em torno da permanência de D. Pedro no Brasil. Na cabeça dos homens que estavam à frente da condução dos negócios políticos do reino, o regresso de D. João a Portugal colocava em risco a proeminência do Brasil, ficando órfão daquele que foi o responsável pela elevação do país à categoria de Reino. Neste passo, ao pretender o regresso também do seu primogênito, o Príncipe Regente, as Cortes desvelavam um desiderato "recolonizador".

Assim, aos 31 de dezembro de 1821, a Câmara de São Paulo representou ao Príncipe Regente D. Pedro I, comunicando o envio de uma deputação com o objetivo de convencê-lo a permanecer no Brasil, pelo menos até nova resolução do Congresso Nacional, após a chegada da representação brasileira em terras lusitanas, apesar do desejo das Cortes Portuguesas do seu retorno imediato. Nessa representação percebe-se claramente a preocupação da bancada paulista quanto aos desígnios recolonizadores das Cortes Portuguesas em relação ao Brasil, ganhando relevo neste contexto o fato de pretenderem "legislar sobre os mais sagrados interesses de todo o Brasil" e de "por meio de baionetas (...) se pretender dar a lei a este reino" 76 .

\footnotetext{
${ }^{76}$ A deputação era composta pelo conselheiro José Bonifácio de Andrada e Silva, o coronel Antônio Leite Pereira da Gama Lobo, e o Marechal José Arouche de Toledo Rondon, Cf. Representação da Câmara de
} 
Assim como a Província de São Paulo, a Representação do Povo do Rio de Janeiro se apropria de um discurso constitucional em manifesto de 02 de janeiro de 1822, para clamar ao Senado da Câmara carioca que inste o Príncipe Regente a permanecer no Brasil. No aludido manifesto lê-se que "conhece-se qual é o estado de oscilação e divergência em que estão todas as províncias do Brasil: o único centro para onde parece que se encaminham suas vistas e suas esperanças é a Constituição". A Representação, após exortar sentimentos de irmandade entre Portugal e Brasil, aduz que “o mais augusto penhor da infalibilidade destes sentimentos é a pessoa do Príncipe Real do Brasil, porque nele reside a grande ideia de toda a aptidão para o desempenho destes planos, como o primeiro vingador do sistema constitucional"77.

Nesta representação do povo do Rio de Janeiro, mais uma vez a questão legislativa aparece como um tema central para a causa do Brasil, especialmente considerando-se a distância física entre as unidades do Reino Unido e as particularidades de cada um dos países, exigindo uma legislação específica, que atendesse a estas exigências. Por trás desta disputa, não se pode deixar de considerar o peso que o escravismo tinha para a economia brasileira, de maneira que se pretendia dispor de um sistema legislativo local, que o colocasse a salvo das inclinações europeias de abolição. Além disso, sob a égide de um regime representativo, como aquele preconizado pelas Cortes de Lisboa, não se poderia conceber a edição de atos normativos sem a presença dos representantes do Brasil, o que reforçava o desejo de estabelecimento de uma Assembleia no Brasil, que atuasse par a par com a de Portugal.

A estratégia de D. Pedro é ambígua, como foi possível demonstrar por ocasião do episódio do ajuntamento militar das tropas portuguesas na Praça do Rossio em

São Paulo, in BONAVIDES, Paulo; AMARAL, Roberto. Textos políticos da história do Brasil, Vol. I, $3^{\mathrm{a}}$ edição, Editora do Senado Federal, Brasília, 2002, p. 399-409.

77 Representação do Povo do Rio de Janeiro, in BONAVIDES, Paulo; AMARAL, Roberto. Textos políticos da história do Brasil, Vol. I, $3^{\mathrm{a}}$ edição, Editora do Senado Federal, Brasília, 2002, p. 528-533. 
fevereiro de 1821 e do juramento da Constituição que seria elaborada pelas Cortes lisboetas. Neste passo, não se pode mensurar até que ponto a resolução, tomada por D. Pedro, de ficar no Brasil, teria sido fruto de sua própria consciência quanto ao papel que poderia desempenhar, em caso de uma separação política do Brasil em relação a Portugal, ou das pressões sofridas por parte dos grupos políticos mais influentes do Brasil. O fato é que, por carta enviada ao seu pai, no mesmo dia 2 de janeiro de 1822 , o Príncipe Regente informa sobre a impossibilidade de cumprir os Decretos 124 e 125 das Cortes, ante a atmosfera de insurreição que poderia tomar conta das Províncias, precipitando um movimento de independência no Brasil e, por conta disso, não encontrava meios de voltar a Portugal.

O desejo de ter uma instância de representatividade puramente brasileira, que atendesse aos anseios de uma legislação atenta às peculiaridades locais (e, em consequência disso, não abalasse os alicerces escravocratas da sociedade), somado à necessidade de acalmar os ânimos divergentes da tropa portuguesa, que nutriam a esperança de que um dia pudessem voltar para seu país de origem, onde tinham deixado suas famílias e seus bens, bem ainda a fim de apaziguar a Bahia, o Pará, Maranhão e Pernambuco, todos sequiosos pela adesão brasileira à causa portuguesa, leva a deputação de São Paulo a requerer ao príncipe a convocação de uma junta de procuradores das províncias para representação dos interesses locais junto à corte real no Rio de Janeiro.

Com efeito, José Bonifácio de Andrada e Silva e Antônio Leite Pereira da Gama Lobo, deputados pelo governo de São Paulo, além de José Arouche de Toledo Rondon, deputado pela Câmara da mesma província e o padre Alexandre Gomes de Azevedo, deputado pelo clero paulista, dirigem-se ao Príncipe Regente, em 26 de janeiro de 1822 , requerendo a convocação de uma junta de procuradores gerais das províncias, para 
advogar perante a corte os interesses de suas regiões ${ }^{78}$. A intenção era que, além dos representantes nas Cortes Gerais e Extraordinárias da Nação Portuguesa, houvesse no Brasil uma "deputação brasílica", para aconselhamento do Príncipe e adoção de medidas consideradas urgentes e necessárias. Mas cumpre notar que esta Junta de Procuradores-Gerais exerceria funções consultivas, sem nenhum poder legiferante. Era uma saída a meio termo encontrada por uma parte da elite no Brasil, que vislumbrava o perigo para a monarquia de uma assembleia com poderes deliberativos, tal como os exemplos da América Espanhola e de São Domingos não os deixavam esquecer.

Para além das razões políticas, econômicas e sociais que levaram ao requerimento de convocação de uma Junta de Procuradores-Gerais das Províncias, é interessante notar, do ponto de vista de uma teoria de direito constitucional ainda em fase embrionária, como na representação acima mencionada, os deputados invocam a "anticonstitucionalidade" dos Decretos 124 e 125 das Cortes Gerais, quando cotejados com as Bases da Constituição já aprovadas pelas Cortes e juradas pelos portugueses. O argumento utilizado é que se:

"as bases, bem que princípios de direito público universal, não podiam
obrigar os brasileiros, enquanto seus legítimos deputados não as adotassem e
jurassem; muito menos os podiam obrigar regras e determinações de direito
público particular sem o exame e aprovação dos seus representantes."79

Ao argumentarem que as "regras de direito público particular" não poderiam obrigar aos brasileiros sem a aprovação de seus representantes, porque nem mesmo as "regras de direito público universal" assim poderiam, acabam por estabelecer uma regra de hierarquia normativa entre as normas da constituição - que denominam "regras de direito público universal" - e as demais regras do ordenamento jurídico - que denominam "regras de direito público particular".

\footnotetext{
${ }^{78}$ BONAVIDES, Paulo; AMARAL, Roberto. Textos políticos da história do Brasil, Vol. I, $3^{\mathrm{a}}$ edição, Editora do Senado Federal, Brasília, 2002, p. 542-548.

${ }^{79}$ Ib idem, p. 542-548.
} 
Mas vale destacar, como o faz Paulo Bonavides, que fica evidenciado que o princípio de uma ordem representativa e constitucional de união das Províncias antecede a Independência do Brasil $^{80}$, especialmente se considerarmos o modo de escolha dos Procuradores-Gerais das Províncias, que seriam nomeados por eleitores de paróquia juntos em cada comarca, de modo semelhante, mas muito mais simplificado, à forma de eleição dos deputados representantes das Cortes em Cádiz e depois em Lisboa, conforme as Instruções para eleição referida linhas acima.

No requerimento dos deputados paulistas ao Príncipe Regente, as referências a D. Pedro como "único pai comum" que restava aos brasileiros após a volta de D. João para Portugal e "anjo tutelar" dos Reinos de Portugal e Brasil, acabam por legitimar uma pretensão soberana do Príncipe, "fundindo a evocação imperial com a afirmação resoluta da estadualidade" ${ }^{\$ 1}$ em detrimento de uma ordem constitucional, calcada sobre princípios de representatividade dos interesses da nação e do povo. A disputa em torno da soberania voltará com muito maior força por ocasião dos debates na Assembleia Geral Constituinte e Legislativa de 1823.

Entre a indefinição do alcance de sentido das ideias constitucionais e a necessidade de autoafirmação da fonte de legitimidade de sua soberania, o Príncipe Regente acaba por atender ao requerimento paulista e, em 16 de fevereiro de 1822 , convoca uma Junta de Procuradores-Gerais das Províncias, "desejando que eles (o povo) tivessem quem os representasse junto a mim... para que os brasileiros melhor conhecessem minha constitucionalidade e o quanto eu me lisonjearia governando a

\footnotetext{
${ }^{80}$ BONAVIDES, Paulo. História Constitucional do Brasil, 2a ed., Ed. Paz e Terra Política, Brasília, 1990, p. 31.

${ }^{81}$ CATROGA, Fernando. "Quimeras de um façanhoso império": o patriotismo constitucional e a independência do Brasil in Memória, escrita da história e cultura política no mundo luso-brasileiro. Rio de Janeiro, Ed. FGV, 2012, p. 330.
} 
contento dos povos" ${ }^{\nexists 2}$. É muito interessante notar o uso da expressão "constitucionalidade" que faz o Príncipe Regente, confirmando que ser ou não constitucional estava, na altura, muito mais ligado a uma postura política do que propriamente à conformação ou não aos preceitos delineados em uma norma jurídica fundadora, hierarquicamente superior e fundamento de validade de todo o restante do ordenamento jurídico. Em outras palavras, se D. Pedro convencesse os povos de que “ele" seria constitucional, o conteúdo dos atos por ele produzidos não importaria muito.

Neste mesmo dia, José Bonifácio de Andrada e Silva redige o Decreto ${ }^{83}$, rubricado pelo Príncipe Regente D. Pedro, instituindo o Conselho de ProcuradoresGerais das Províncias do Brasil, em que reafirma a necessidade de uma "Constituição da Monarquia" que desse ao Brasil "uma final organização sábia, justa e adequada aos seus inalienáveis direitos, decoro e futura felicidade", ressalvando, entretanto, o seu próprio papel fundamental nesse processo, como "centro de união e de força", ao lado do sistema constitucional, como "centro de meios e de fins", que ele próprio jurou dar ao Brasil. D. Pedro houve por bem "mandar convocar um conselho de procuradores-gerais das províncias do Brasil, que as representem interinamente, nomeando aquelas, que têm até quatro deputados em cortes, um; as que têm de quatro até oito, dois; e as outras daqui pra cima, três", que poderiam ser removidos de seus cargos se não desempenhassem devidamente suas obrigações, mediante requerimento de dois terços das câmaras das províncias.

É interessante notar, na exposição de motivos do Decreto de 16 de fevereiro de 1822, uma relação, desde logo, ambivalente e conflituosa, entre a Monarquia e a Constituição. Como conciliar a monarquia, como "centro de união e de força",

\footnotetext{
${ }^{82}$ BONAVIDES, Paulo. História Constitucional do Brasil, 2 2 ed., Ed. Paz e Terra Política, Brasília, 1990, p. 23.

${ }^{83}$ As expressões em destaque constam do Decreto de 16 de fevereiro de 1822, in BONAVIDES, Paulo; AMARAL, Roberto. Textos políticos da história do Brasil, Vol. VIII, $3^{a}$ edição, Editora do Senado Federal, Brasília, 2002, p. 120-121.
} 
personificada na figura de D. Pedro, com a Constituição, "centro de meios e de finns"? Como conciliar a força com a limitação do poder e, consequentemente, da própria força? $\mathrm{Na}$ visão de $\mathrm{D}$. Pedro, subordinando a segunda à primeira, por meio da subordinação da Constituição à soberania do monarca, que, inclusive, pela sua "magnificência", limitaria o próprio poder, dando ele mesmo a Constituição, que, contudo, sempre estaria sujeita à sua força. Essa dualidade vai permanecer durante todo o processo constituinte brasileiro, emergindo nos debates travados na Assembleia Constituinte de 1823. O Decreto estabeleceu ainda o sistema eleitoral para a escolha dos procuradores, com base no Decreto de 07 de março de 1821, expedido por D. João VI, para regulamentar a eleição dos deputados brasileiros que tomariam assento nas Cortes de Lisboa.

O Conselho de Procuradores-Gerais das Províncias do Brasil seria presidido por D. Pedro e teria as seguintes atribuições: 1) aconselhar o Príncipe em todos os negócios mais importantes e difíceis do Reino; 2) examinar os grandes projetos de reforma, que se devam fazer na administração geral e particular do Estado; 3) propor medidas e planos urgentes e vantajosos ao bem do Reino Unido e à prosperidade do Brasil; e, finalmente, 4) advogar e zelar pelas utilidades de sua província respectiva. Os ministros e secretários de Estado teriam assento e voto no Conselho, o qual entraria no exercício de suas funções tão logo estivessem reunidos os procuradores de três províncias. Cumpre notar que o Conselho, como o seu próprio nome realça, tinha por função o aconselhamento do monarca, possuindo, portanto, natureza consultiva e não havia previsão de elaboração de uma constituição, mesmo tendo presente a referência a ela na exposição de motivos. Disto se infere que, para D. Pedro, caso alguma constituição viesse a ser elaborada para o Brasil, não o seria por meio de representantes eleitos e sim, 
por simples outorga, nos moldes de uma Ata, como preconizado por José da Silva Lisboa, assemelhando-se muito mais a uma Carta Constitucional.

Além disso, merece destaque que o formato do Conselho estava a meio termo entre as Cortes Antigas do Reino, próprias de uma concepção do Antigo Regime e da monarquia absoluta, e as Assembleias Constituintes, órgãos de representação dos interesses da nação e titulares do poder de elaboração da constituição, que estabeleceria a divisão do poder, distribuindo as funções legislativa, executiva e judiciária entre órgãos diversos, autônomos e independentes entre si, e ainda garantidora de certos direitos fundamentais dos indivíduos. Isto porque nem podiam ser considerados Cortes, nos moldes antigos, já que seus componentes, os procuradores-gerais, seriam eleitos pelos eleitores de paróquia, e não pelas antigas ordens do reino; nem tampouco o Conselho podia ser considerado uma Assembleia Constituinte, pois, como visto, não estava entre as suas funções a elaboração de uma constituição e sua natureza era consultiva. A propósito, o autor intelectual do Conselho, José Bonifácio, advertiu claramente que esse seria uma forma de evitar "as desordens das Assembleias

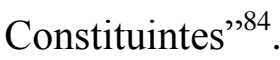

Mas logo esse hibridismo reforçará o argumento daqueles que sustentavam ser o momento propício para a convocação de genuínas Cortes no Brasil, especialmente diante das notícias acerca do "despotismo" do Congresso de Lisboa. É o caso, por exemplo, das reflexões extraídas do Correio Braziliense, reproduzidas pelo "O Constitucional", da Bahia, onde se lê que, apesar de reconhecer o decreto de 16 de fevereiro como um "bom começo de rumo", não bastava, porque, para Hipólito José da Costa, só um Parlamento brasileiro poderia conhecer a vontade geral dos povos, composto de "suficiente número de membros, escolhidos por toda a massa da nação" e

\footnotetext{
${ }^{84}$ SOUSA, Octávio Tarquínio. O pensamento vivo de José Bonifácio apud DA SILVA, Maria Beatriz Nizza. Movimento Constitucional e Separatismo no Brasil (1821-1823). Lisboa: Livros Horizonte, p. 99 e nota de rodapé $n^{\circ} 2$.
} 
o Conselho, ao contrário, pelos poucos indivíduos que o integravam, constituiria uma "uma farsa de representação nacional" 85 . Da mesma forma as "Considerações sobre as Cortes do Brasil”, publicadas no mesmo mês em 1822, no Rio de Janeiro, aduziam que “a convocação de uma Assembleia Legislativa de todas as Províncias do Brasil, sem dependência de Portugal é hoje o grande objeto da geral atenção"86.

Apenas três meses depois da convocação do Conselho de Procuradores-Gerais das Províncias, no dia 23 de maio de 1822, o povo do Rio de Janeiro, por meio do Senado da Câmara, faz chegar ao conhecimento do Príncipe Regente uma representação, elaborada em 20 de maio, em que tece severas críticas aos procedimentos adotados pelas Cortes Gerais e Extraordinárias da Nação Portuguesa, que, passando de representante do povo de Portugal a soberana de toda a nação, perjurou as próprias bases por ela estabelecidas, faltando aos princípios universais que proclamara, conferindo tratamento indigno ao Brasil. A representação aduz que "as províncias coligadas do Brasil têm reconhecido quanto seja impossível persistir na expectação de que, a mais de duas mil léguas de distância delas, se tratem com verdadeira igualdade os seus direitos e a justiça da sua causa" ${ }^{~} 87$, requerendo a convocação de uma assembleia geral das províncias do Brasil,

\begin{abstract}
"representadas por um número competente de deputados, que não poderão ser menos de cem, nomeados por novos eleitores paroquiais, eleitos pelo povo, com poderes especiais para esse fim, cujas atribuições sejam: deliberar em sessão pública sobre as justas condições com que o Brasil deve permanecer unido a Portugal - examinar se a constituição, que se está fazendo nas Cortes Gerais de Lisboa, é no seu todo adaptada ao Brasil; e sobre as bases ali decretadas e aqui juradas, estabelecer as emendas, reformas e alterações, com que a mesma constituição deve ser recebida e jurada no Brasil. - E porque este não está seguro e menos pode prosperar sem um corpo legislativo Brasileiro, a mesma assembleia entrará, apenas instalada, no
\end{abstract}

\footnotetext{
${ }^{85}$ O Constitucional, $\mathrm{n}^{\mathrm{o}}$ 56, de 17 de agosto de 1822.

${ }^{86}$ Considerações sobre as Cortes do Brasil, Rio de Janeiro, na Tipografia do Diário, 1822, p.3-5, apud NIZZA DA SILVA, Maria Beatriz. Movimento Constitucional e Separatismo no Brasil (1821-1823). Lisboa: Livros Horizonte, 1988, p. 110-111.

${ }^{87}$ Representação que faz o povo do Rio de Janeiro, por meio do Senado da Câmara, in BONAVIDES, Paulo; AMARAL, Roberto. Textos políticos da história do Brasil, Vol. I, $3^{\mathrm{a}}$ edição, Editora do Senado Federal, Brasília, 2002, p. 571-579.
} 
exercício do poder legislativo, que lhe é essencial e inseparável da soberania do Brasil",88.

Essa representação do povo do Rio de Janeiro tem uma importância capital para o processo constituinte brasileiro em 1822. Da mesma forma que, um ano antes, a tropa portuguesa capitaneou os acontecimentos de 26 de fevereiro, na Praça do Rossio, no Rio de Janeiro, marcando a adesão do Brasil ao movimento constitucional iniciado no Porto, agora os brasileiros é quem exigiam a consolidação do movimento, por meio da convocação de uma Assembleia Geral das Províncias, com poderes para deliberar sobre a adequação da Constituição que estava a ser elaborada em Portugal e, além disso, com poderes legislativos para evitar a ingerência portuguesa nos negócios brasileiros, assegurando a soberania do Brasil.

O Senado da Câmara do Rio de Janeiro, composto por José Clemente Pereira, João Soares Bulhões, Domingos Viana Gurgel do Amaral, Domingos Antunes Guimarães e José Antônio dos Santos Xavier, acrescenta em seu pronunciamento ${ }^{89}$ outras razões para a convocação de uma Assembleia Legislativa do Brasil. Assim, destaca, mais uma vez, a importância de um Poder Legislativo genuinamente brasileiro. Com efeito, aduz que o Príncipe Regente "por estar despido do poder de fazer leis, não pode soltar as velas à energia e patriotismo que o caracteriza", em prejuízo dos negócios do Brasil, especialmente da agricultura, ciências, artes, indústria e o comércio, cujas dádivas "só um corpo legislativo brasileiro lhes pode liberalizar", destacando ainda que o Brasil deveria aumentar a sua Marinha e preparar suas forças de terra, "que só o Poder Legislativo pode proporcionar".

\footnotetext{
${ }^{88}$ Representação que faz o povo do Rio de Janeiro, por meio do Senado da Câmara, in BONAVIDES, Paulo; AMARAL, Roberto. Textos políticos da história do Brasil, Vol. I, $3^{\mathrm{a}}$ edição, Editora do Senado Federal, Brasília, 2002, p. 571-579.

89 As expressões em destaque podem ser encontradas in BONAVIDES, Paulo; AMARAL, Roberto. Textos políticos da história do Brasil, Vol. I, $3^{\text {a }}$ edição, Editora do Senado Federal, Brasília, 2002, p. 582588.
} 
Mas nem todos concordavam com o teor da representação do Senado da Câmara do Rio de Janeiro, como, por exemplo, José da Silva Lisboa, autor das "Reclamações dos direitos do Brasil", monarquista convicto. A Sentinela Bahiense, taxando de “delirante" a aludida representação, divulga a Reclamação do Brasil n 14, em que o futuro Visconde de Cairú a classifica de "anticonstitucional e incendiária, de sedução popular e de tremenda irresponsabilidade", aduzindo que uma Assembleia Legislativa brasileira paralela ao Congresso de Lisboa constituiria um plano "anômalo, cerebrino e extravagante", contrário às Bases da Constituição juradas pelo Brasil pouco tempo antes. E, destacando a volatilidade dos sentidos políticos que esse novo vocabulário constitucional estava a experimentar, indaga:

\begin{abstract}
“onde está o nosso juramento às Bases da Constituição? (...) Assim se muda a cada mês, ou semana, de opinião e resoluções como de modas, e em matéria tão tormentosa da alteração de governo? Assim tacitamente se revogam os poderes dados aos nossos deputados das Cortes?"
\end{abstract}

Mas, baldados os esforços contrários à ideia de convocação de uma Assembleia Legislativa brasileira, D. Pedro condiciona seu consentimento à proposta de convocação de uma Assembleia Legislativa do Brasil ao conhecimento da vontade do povo das demais províncias". Para tanto, entretanto, bastou o conhecimento da "vontade do povo” da Vila Real da Praia Grande, que, por intermédio do seu Senado da Câmara, no dia 26 de maio, levou à presença de Sua Alteza Real um abaixo assinado do povo daquela vila, rogando a convocação de

"uma assembleia geral de deputados das províncias deste reino, que
escolhidos a aprazimento dos povos dele e investidos do poder legislativo de
acordo com as cortes extraordinárias e constituintes de Portugal deliberem,

${ }^{90}$ Reclamação do Brasil $n^{o} 14$, in Sentinela Bahiense, $n^{\circ} 3$, de 17 de julho de 1822, apud NIZZA DA SILVA, Maria Beatriz. Movimento Constitucional e Separatismo no Brasil (1821-1823). Lisboa: Livros Horizonte, 1988, p. 114.

91 Termo de Vereação extraordinária do Senado da Câmara do Rio de Janeiro de 23 de maio de 1822, extraído de CINTRA, F. Assis. D. Pedro I e o grito de independência. Ed. Melhoramentos, São Paulo, 1921, p. 196-204. 
decretem e legislem tudo quanto for a bem tanto do Brasil como de toda a Monarquia portuguesa em geral" ${ }^{\prime 92}$.

A disputa ideológica entre o grupo de José Clemente Pereira e Joaquim Gonçalves Ledo, designados por Pereira das Neves de "elite brasiliense", mais democrático do que monárquico ${ }^{93}$ e o grupo de José Bonifácio, denominado de “elite coimbrã,94, mais conservador, que culminou com a formatação do Conselho de Procuradores muito assemelhada a um Conselho de Estado, ganhava agora novos rumos, especialmente a partir de uma iniciativa de Joaquim Gonçalves Ledo, eleito Procurador pela Província do Rio de Janeiro junto ao Conselho de Procuradores-Gerais das Províncias.

Com efeito, Gonçalves Ledo engendrou a $1^{\mathrm{a}}$ reunião do Conselho de Procuradores, repentinamente e mesmo sem a sua composição completa, para o dia 02 de junho de 1822 e, tendo comparecido apenas mais dois Procuradores, José Mariano de Azevedo Coutinho, também representante do Rio de Janeiro e Lucas José Obes, representando a província da Cisplatina, acertaram-se para elaborar uma Representação, corroborando a súplica do povo, dirigida pelo Senado da Câmara do Rio de Janeiro no dia 23 de maio de 1822, para a convocação de uma Assembleia Geral das Províncias do Brasil. Diante desse movimento irreversível, José Bonifácio e o restante do ministério não viram outra alternativa a não ser aderir à representação para não ficarem à margem da história.

Assim, no dia 03 de junho, o Príncipe Regente recebe a referida representação, subscrita pelos mencionados procuradores, bem como pelos ministros de Estado José Bonifácio de Andrada e Silva, Caetano Pinto de Miranda Montenegro, Joaquim de

\footnotetext{
92 Representação da Vila Real da Praia Grande extraído de CINTRA, F. Assis. D. Pedro I e o grito de independência. Ed. Melhoramentos, São Paulo, 1921,p. 383-385.

${ }^{93}$ NIZZA DA SILVA, Maria Beatriz. Movimento Constitucional e Separatismo no Brasil (1821-1823). Lisboa: Livros Horizonte, 1988, p. 100.

94 NEVES, Lúcia Maria Bastos Pereira das. Corcundas e constitucionais: a cultura e política da independência (1820-1822). Rio de Janeiro: Revan/FAPERJ, 2003, p. 86-88.
} 
Oliveira Álvares e Manuel Antônio Farinha, aduzindo, após destacar que o Congresso

de Lisboa teria perdido o norte que o devia guiar, que "a âncora que pode segurar a nau

do Estado, a cadeia que pode ligar as províncias do Brasil aos pés do trono de V.A.R., é

a convocação de Corte que, em nome daquela que representamos, instantemente

requeremos a V.A.R.” ${ }^{95}$. Vale destacar ainda o seguinte trecho da representação:

“o Brasil tem direitos inauferíveis para estabelecer o seu governo e a sua independência, direitos tais que o mesmo Congresso lusitano reconhecia e jurou. As leis, as constituições, todas as instituições humanas, são feitas para os povos, não os povos para elas. É deste princípio indubitável que devemos partir: as leis formadas na Europa podem fazer a felicidade da Europa, mas não a da América. O sistema europeu não pode, pela eterna razão das coisas, ser o sistema americano" 96 .

No mesmo dia D. Pedro firma o Decreto de 03 junho de 1822, redigido por José

Bonifácio, mandando convocar uma Assembleia Geral Constituinte e Legislativa,

composta de deputados das Províncias do Brasil, nos seguintes termos:

\begin{abstract}
"Havendo-me representado os procuradores-gerais de algumas províncias do Brasil já reunidos neste corte, e diferentes câmaras e povo de outras, o quanto era necessário, e urgente para a mantença da integridade da Monarquia Portuguesa, e justo decoro do Brasil, a convocação de uma Assembleia Luso-Brasiliense, que investida daquela porção de soberania, que essencialmente reside no povo deste grande, e riquíssimo continente, constitua as bases sobre que se devam erigir a sua independência, que a natureza marcara, e de que já estava de posse, e a sua União com todas as outras partes integrantes da grande família portuguesa, que cordialmente deseja: E reconhecendo eu a verdade e a força das razões que me foram ponderadas, nem vendo outro modo de assegurar a felicidade deste reino, manter uma justa igualdade de direitos entre ele e o de Portugal, sem perturbar a paz, que tanto convém a ambos, e tão própria é de povos irmãos: Hei por bem, e com o parecer do meu conselho de Estado, mandar convocar uma Assembleia Geral Constituinte e Legislativa, composta de deputados das províncias do Brasil novamente eleitos na forma das instruções, que em conselho se acordarem, e que serão publicadas com a maior brevidade."97 (destaquei)
\end{abstract}

\footnotetext{
95 Representação dos procuradores e do ministério corroborando a súplica do povo dirigida pelo Senado da Câmara do Rio de Janeiro no dia 23 de maio de 1822, extraído de CINTRA, F. Assis. D. Pedro I e o grito de independência. Ed. Melhoramentos, São Paulo, 1921, p. 205-207.

${ }^{96}$ Representação dos procuradores e do ministério corroborando a súplica do povo dirigida pelo Senado da Câmara do Rio de Janeiro no dia 23 de maio de 1822, extraído de CINTRA, F. Assis. D. Pedro I e o grito de independência. Ed. Melhoramentos, São Paulo, 1921, p. 205-207.

${ }_{97}$ BONAVIDES, Paulo; AMARAL, Roberto. Textos políticos da história do Brasil, Vol. VIII, $3^{\mathrm{a}}$ edição, Editora do Senado Federal, Brasília, 2002, p. 122-123.
} 
No dia 19 de junho de 1822, José Bonifácio de Andrada e Silva faz expedir as instruções para a eleição dos deputados da Assembleia Constituinte e Legislativa do Brasil $^{98}$. Apesar de ser um Estado e uma nação ainda em formação ${ }^{99}$, a complexidade da sociedade brasileira naquela época e seu grau de amadurecimento relativamente às aspirações representativas encontram-se bem delineadas nas instruções expedidas por José Bonifácio, que estabeleceu um sistema eleitoral em duas fases, em que primeiro seriam eleitos por voto direto os eleitores de paróquia, segundo uma regra de proporcionalidade, que, posteriormente, iriam nomear os deputados para a Assembleia $^{100}$.

Com efeito, a escolha dos eleitores seria realizada na paróquia da povoação ou freguesia, de acordo com o número de fogos de sua igreja. Para as igrejas com até cem fogos, um eleitor; naquelas com mais de cento e oitenta fogos e menos de duzentos, dois eleitores de paróquia; onde houvesse mais de duzentos e cinquenta fogos e menos de trezentos, seriam escolhidos três eleitores e assim progressivamente. Todo cidadão casado e os solteiros com mais de vinte e um anos de idade, desde que não fossem filhos-família, teriam direito a votar nas eleições paroquiais, exigindo-se para todos pelo menos um ano de residência na freguesia onde iriam votar. Os religiosos regulares, os estrangeiros não naturalizados, os criminosos e todos aqueles que recebessem salários ou soldadas, não tinham direito a votar, com exceção dos Guarda-Livros, dos primeiros caixeiros das casas de comércio, dos criados da Casa Real que não fossem de galão branco e dos administradores das fazendas rurais e fábricas. Vale registrar que os

\footnotetext{
${ }^{98}$ BONAVIDES, Paulo; AMARAL, Roberto. Textos políticos da história do Brasil, Vol. VIII, $3^{\mathrm{a}}$ edição, Editora do Senado Federal, Brasília, 2002, p. 124-133.

${ }^{99}$ JANCSÓ, István (org.). Brasil: Formação do Estado e da Nação. São Paulo, Hucitec, Ed. Unijuí, Fapesp, 2003.

${ }^{100}$ Sobre as discussões no Conselho de Procuradores do modelo de eleição a ser adotado para a Assembleia Geral Constituinte e Legislativa do Brasil, especialmente as posições de Joaquim Gonçalves Ledo, que defendia um sistema de eleições diretas, e de Estevão Ribeiro de Rezende, que propugnava por um modelo simplificado de eleições semi-indiretas, ver NIZZA DA SILVA, Maria Beatriz. Movimento Constitucional e Separatismo no Brasil (1821-1823). Lisboa: Livros Horizonte, 1988, p. 115-131.
} 
analfabetos tinham direito a voto, fazendo-o oralmente e depois assinando com uma cruz.

Para ser eleitor de paróquia, além das qualidades requeridas para votar, a pessoa deveria possuir domicílio certo na província pelo menos há quatro anos, contar com vinte e cinco anos de idade, ser homem probo e honrado, de bom entendimento, sem nenhuma sombra de suspeita e inimizade à causa do Brasil e de decente subsistência por emprego, indústria ou bens. Os eleitores escolhidos, dentro de quinze dias depois de sua nomeação, deveriam reunir-se no Distrito que lhes fosse marcado, tendo previsto as instruções as localidades em que tal reunião deveria ocorrer ${ }^{101}$, ressalvando que os eleitores das freguesias das Vilas e lugares intermédios deveriam concorrer ao Distrito que lhes fosse mais cômodo dentre os apontados.

Os deputados da Assembleia Geral Constituinte e Legislativa do Reino do Brasil seriam distribuídos proporcionalmente entre as províncias, sendo dois para a Província Cisplatina, três para o Rio Grande do Sul, um para Santa Catarina, nove para São Paulo, um para Mato Grosso, dois para Goiás, vinte para Minas Gerais, oito para o Rio de Janeiro, um para a Capitania, treze para a Bahia, cinco para Alagoas, quinze para

\footnotetext{
${ }^{101}$ Capítulo III, 10. "Para facilitar a reunião dos eleitores, ficam sendo (só para este efeito), cabeças de Distrito os seguintes:" Na Província Cisplatina: Montevidéu, Maldonado e Colônia. Na Província do Rio Grande do Sul: Vila de Porto Alegre, Vila do Rio Grande, Vila do Rio Pardo e Vila de S. Luís. Na Província de Santa Catarina: Vila do Desterro, Vila de S. Francisco e Vila de Laguna. Na Província de S. Paulo: A Cidade de S. Paulo, Vila de Santos, Vila de Itu, Vila de Curitiba, Vila de Paranaguá e Vila de Taubaté. Na Província de Mato Grosso: Vila Bela, Vila de Cuiabá e Vila do Paraguai Diamantino. Na Província de Goiás: Cidade de Goiás, Julgado de Santa Cruz e Julgado de Cavalcanti. Na Província de Minas Gerais: Vila de São João Del Rei, Vila da Princesa da Campanha, Garanhuns, Vila das Flores, Vila da Barra, Carinhanha, Campo Largo e Cabrobó. Na Província da Paraíba: Cidade da Paraíba, Vila Real e Vila da Rainha da Campina Grande. Na Província do R.G. do Norte: Cidade do Natal e Vila Nova da Princesa. Na Província do Ceará: Vila do Acarati, Vila do Sobral, Vila do Icó, Vila de S. Bento de Tamanduá, Vila Rica, Cidade de Mariana, Vila de Pitangui, Vila do Príncipe, Vila de N.S. do Bom Sucesso e Vila do Paracatu. Na Província do Rio de Janeiro: A capital, Vila de S. João Marcos, Vila de S. Antônio de Sá e Macaé. Na Província do Espírito Santo: Vila da Vitória e Vila de S. Salvador. Na Província da Bahia: Vila de Porto Seguro, Vila de São Mateus, Vila de S. Jorge, Vila do Rio das Contas, Cidade de S. Salvador, Vila de S. Amaro, Vila do Itapicuru, Vila da Cachoeira, Vila da Jacobina, Vila de Sergipe, Vila Nova de S. Antônio. Na Província das Alagoas: Vila de Porto Calvo, Vila das Alagoas e Vila do Penedo. Na Província de Pernambuco: Olinda, Recife e Cidades. Na Província do Piauí: Vila da Parnaíba e Cidade de Oeiras. Na Província do Maranhão: Cidade de S. Luís, Vila de Itapicuru-Mirim e Vila de Caxias. Finalmente, na Província do Pará: Cidade de Belém, Vila Vistosa, Santarém, Barcelos, Marajó, Vila Nova da Rainha, Vila do Crato, Olivença e Cametá.
} 
Pernambuco, cinco para a Paraíba, um para o Rio Grande do Norte, oito para o Ceará, um para o Piauí, quatro para o Maranhão e três para o Pará, totalizando cem deputados.

Para ser nomeado deputado, a pessoa deveria reunir todas as condições previstas para ser eleitor de paróquia, acima já identificadas, bem como ainda ser natural do Brasil ou, contanto que tivesse doze anos de residência no Brasil, de qualquer outra parte da Monarquia Portuguesa e, sendo estrangeiro, que tivesse doze anos de estabelecimento com família além dos da sua naturalização. Para ser deputado, ainda, a pessoa deveria possuir à maior instrução reconhecidas virtudes, verdadeiro patriotismo e decidido zelo pela causa do Brasil. Poderiam ser reeleitos os deputados do Brasil que estivessem servindo nas Cortes de Lisboa.

Os deputados seriam remunerados pelo Tesouro Público de sua respectiva província, suspendendo-se todos e quaisquer outros vencimentos pagos pelo Tesouro Público, decorrentes de empregos, pensões e outros. O valor da remuneração do deputado seria de seis mil cruzados anuais, pagos a mesadas no princípio de cada mês e, caso a província não tivesse condições de arcar com tal despesa, o pagamento seria feito pelo Cofre Geral do Tesouro do Brasil, sob a condição de posterior ressarcimento pela respectiva província.

Nenhum cidadão poderia escusar-se de aceitar a nomeação para exercer as funções de deputado e, uma vez eleito, ficaria investido de toda a plenitude de poderes necessários para as augustas funções da Assembleia, a qual seria instalada tão logo estivessem reunidos cinquenta e um deputados.

No capítulo dedicado às eleições para deputados, as instruções expedidas por José Bonifácio de Andrada e Silva previam que os eleitores das freguesias, munidos dos seus diplomas, se apresentariam à autoridade civil mais graduada do Distrito, que serviria de presidente provisoriamente, o qual ficaria incumbido de designar o dia e o 
local da reunião, mandando intimar a Câmara para a execução dos preparativos necessários. No dia aprazado, reunidos os eleitores presididos pela dita autoridade, depois de fazer-se a leitura dos capítulos IV e $\mathrm{V}$ das Instruções, nomeariam por aclamação um secretário e dois escrutinadores, para examinarem os diplomas dos eleitores. Em seguida, seria eleito o novo presidente, dentre os eleitores de paróquia, por escrutínio secreto, cédulas de votação e pluralidade (maioria) de votos.

A eleição dos deputados seria feita por cédulas individuais, assinadas pelo votante e tantas vezes repetidas quantos fossem os deputados que deveria dar a província. Em seguida, o presidente faria publicar o nome daquele que obtivesse a pluralidade de votos e o secretário formaria a necessária relação de nomes dos eleitos e seus respectivos votos. Preenchido o número e verificados os requisitos exigidos para ser eleito deputado, seria lavrado o termo da eleição, assinado por todo o colégio, do qual seriam extraídas duas cópias, sendo que uma delas seria remetida para a Secretaria de Estado dos Negócios do Brasil e a outra, por carta selada e fechada, seria remetida à Câmara da capital. Recebidas pela Câmara da capital todas as remessas dos diferentes distritos, deveria marcar o dia e a hora em que seriam abertas as cartas, "na presença dos homens bons e do povo", zelando o presidente da Câmara para que fizesse reconhecer pelos presentes que as cartas estavam intactas e publicando os nomes daqueles que obtiveram a maioria dos votos.

Para prevenir eventuais dúvidas de interpretação quanto aos dispositivos das instruções para eleição dos deputados da Assembleia Geral Constituinte e Legislativa do Brasil, D. Pedro I fez expedir um Decreto ${ }^{102}$ aos 3 de agosto de 1822 , em que, por exemplo, determina que, com o fim de abreviar a instalação da Assembleia, em lugar de nova eleição, no caso de uma mesma pessoa ser eleita por províncias de diversas, seja

\footnotetext{
102 BONAVIDES, Paulo; AMARAL, Roberto. Textos políticos da história do Brasil, Vol. VIII, $3^{\mathrm{a}}$ edição, Editora do Senado Federal, Brasília, 2002, p. 134-135.
} 
considerado eleito o deputado que se seguir em maioria de votos ao primeiro colocado e que acabou por ser nomeado para a província em que mantinha domicílio. Outro exemplo é que D. Pedro I ordenou, em caso de eleição de deputado que esteja servindo nas Cortes de Lisboa, que, até a chegada daquele deputado, o supra, interinamente, o imediato em maioria de votos, devendo, porém, cessar o seu exercício na Assembleia, logo que o ausente tiver chegado ao Brasil.

No dia 14 de abril de 1823, José Bonifácio de Andrada e Silva, membro do Conselho de Estado, ministro e secretário de Estado dos Negócios do Império e Estrangeiros, redige o Decreto Imperial designando, para o dia 17 de abril de 1823, a data da primeira reunião dos deputados da Assembleia, onde, começando pela nomeação do presidente, deveriam formar a junta preparatória para verificação dos poderes e organizar o regimento interno da Assembleia, dando parte ao Imperador, por uma solene deputação, do dia assinalado para a abertura dos trabalhos. Assim, sob a presidência do Bispo Capelão-Mor, instalou-se a Primeira Assembleia Nacional Constituinte do Brasil em 03 de maio de 1823. 


\section{CAPÍTULO 2 - VOCABULÁRIO POLÍTICO-CONSTITUCIONAL DA ASSEMBLEIA GERAL CONSTITUINTE E LEGISLATIVA DO BRASIL}

Símbolo da regeneração vintista iniciada em 1820, a palavra constituição parecia exprimir o anseio político de todos os membros das elites política e intelectual, tanto do Brasil, quanto de Portugal.

Em praticamente todas as discussões de cunho político, invocava-se o termo constituição como supedâneo de posições ideológicas muito bem definidas, merecendo destaque o crescente número de periódicos no Brasil, principalmente a partir do movimento constitucionalista de 1821, propiciados pela liberdade de imprensa, os quais exerceram importante papel de mobilização ideológica nessa disputa de sentido.

Podem ser destacados, exemplificativamente, os seguintes jornais: A Malagueta (editado por Luís Augusto May), Revérbero Constitucional Fluminense (editado por Joaquim Gonçalves Ledo e o padre Januário Barbosa), Correio do Rio de Janeiro (editado por João Soares Lisboa), O Espelho, Correio Brasiliense e o Regulador Brasílico (passando a chamar-se Regulador Brasileiro depois da independência), todos estes editados no Rio de Janeiro. Outras províncias também conheceram importantes publicações, como a Idade d'Ouro, o Diário Constitucional (que passou a chamar-se

posteriormente simplesmente $\mathrm{O}$ Constitucional), o Analisador Constitucional, o Espreitador Constitucional e a Abelha, todos da Bahia.

Convém sublinhar que, não obstante a designação comum de "constitucional", não raramente estes periódicos adotavam posturas completamente antagônicas umas às outras, demonstrando e realçando a disputa ideológica de sentido acerca dos limites e possibilidades do conceito de constituição e da qualidade de ser constitucional ou não (anticonstitucional, segundo o termo em voga na época). 
Entre os anos de 1821 e 1823 foram publicados no Brasil inúmeros folhetos e panfletos, editados em Portugal durante o movimento de 1820, os quais "se destinavam a propagar a proposta de um constitucionalismo monárquico, profundamente inspirado nas ideias pregadas durante a revolução da Espanha"103. Esses escritos eram chamados de "folhetos constitucionais" pelo livreiro Paulo Martin, como o caso da Constituição explicada, do Constitucional justificado ou do Catecismo político constitucional e ainda o Diálogo entre o corcunda abatido, o constitucional exaltado, o Alfaiate constitucional, o Diálogo entre a Constituição e o despotismo e o Diálogo instrutivo em que se explicam os fundamentos de uma Constituição ${ }^{104}$.

Ao longo do ano de 1821, dos cerca de cem folhetos publicados no Rio de Janeiro, vinte e seis apresentavam em seus respectivos títulos a palavra constituição ou algum dos seus derivados, como constitucional e anticonstitucional ${ }^{105}$. A principal preocupação nestes escritos de circunstância era explicar aos leitores o conceito que advogavam de constituição e em que consistia um governo organizado em bases constitucionais. É o caso, por exemplo, da Constituição explicada, que assim escrevia: "o Sr. Benjamin Constant, mui sabiamente nos instruiu, escrevendo que a
Constituição não era um ato de hostilidade, mas um ato de união que
determinam as relações recíprocas do monarca e do povo, sancionando os
meios de se defenderem e de se apoiarem e de se felicitarem mutuamente."106

Os autores recorriam aos diálogos e aos manuais com o objetivo de melhor explicitar aos leigos o conceito de constituição. O Diálogo instrutivo em que se explicam os fundamentos de uma Constituição afirmava ser a constituição "uma lei fundamental, que regulava a forma pela qual uma Nação devia ser governada e

\footnotetext{
103 NEVES, Lúcia Maria Bastos Pereira das. Corcundas e constitucionais: a cultura política da independência (1820-1822). Rio de Janeiro: REVAN: FAPERJ, 2003, p. 39.

${ }^{104} \mathrm{Ib}$ idem, p. 40-41 e 98.

105 NEVES, Lúcia Maria Bastos Pereira das. Corcundas e constitucionais: a cultura política da independência (1820-1822). Rio de Janeiro: REVAN: FAPERJ, 2003. Vale a pena ainda conferir a seleção de periódicos e folhetos em que a autora identifica os respectivos redatores e autores, bem como o seu local e ano de publicação.

${ }^{106}$ Constituição explicada. Reimpresso no Rio de Janeiro: Imp. Régia, 1821, f. 1.
} 
estabelecia máximas gerais, a que todos deviam satisfazer"107. O Manual Político do Cidadão Constitucional, através do método de perguntas e respostas, indagava "que coisa é Constituição?”, respondendo que seriam “as Leis Fundamentais pelas quais um povo estabeleceu o modo porque quer ser governado e determina os limites do poder que confere às autoridades a que se sujeita" ${ }^{\prime 108}$.

Era muito comum ainda a distribuição de exemplares de constituições, como a Constituição espanhola de Cádiz de 1812 e a Constituição portuguesa de 1822, além de proclamações, como o juramento das bases dessa mesma Constituição lusitana e ainda cartas de diversos leitores discutindo temas de alcance constitucional, juntamente com os periódicos, folhetos e panfletos comercializados pelos livreiros da cidade do Rio de Janeiro, no afã de instruir os leitores sobre as questões relacionadas àquele termo pouco conhecido até então, em uma espécie de "pedagogia do constitucionalismo"109.

Além das publicações acima referidas, merecem destaque os papéis desempenhados pela Universidade de Coimbra ${ }^{110}$ reformada e pelas sociedades secretas, notadamente a maçonaria, no processo de construção de uma nova cultura política, que influenciou o processo de independência brasileira.

No dia 28 de maio de 1822 constituiu-se a loja maçônica do Grande Oriente, a partir da fusão das lojas Commercio e Artes, União e Tranquilildade e Esperança de Niterói, tendo sido escolhido José Bonifácio de Andrada e Silva como seu primeiro

\footnotetext{
107 Diálogo instrutivo em que se explicam os fundamentos de huma Constituição e a divisão das autoridades que a formão e executão. (Por hum Patriota Amigo da Razão). Rio de Janeiro: Tip. Real, 1821, p. 3.

${ }^{108}$ Manual Político do cidadão constitucional. Lisboa: Nova Impressão da Viúva Neves \& Filhos, 1820, p. 4. Apud NEVES, Lúcia Maria Bastos Pereira das. Corcundas e constitucionais: a cultura política da independência (1820-1822). Rio de Janeiro: REVAN: FAPERJ, 2003, p. 149.

${ }^{109}$ Para a expressão "pedagogia do constitucionalismo", cf. NEVES, Lúcia Maria Bastos Pereira das. Corcundas e constitucionais: a cultura política da independência (1820-1822). Rio de Janeiro: REVAN: FAPERJ, 2003, p. 113.

${ }^{110}$ Basta ver, por exemplo, que, dentre os deputados brasileiros eleitos para as Cortes de Lisboa, cerca de $46 \%$ haviam frequentado os cursos de Coimbra, a maioria o de Leis e Cânones. Cf. NEVES, Lúcia Maria Bastos Pereira das. Corcundas e constitucionais: a cultura política da independência (1820-1822). Rio de Janeiro: REVAN: FAPERJ, 2003, p. 33 e 49.
} 
Grão-Mestre da Ordem. Na estrutura hierárquica do Grande Oriente ainda se encontravam outros personagens importantes na história da independência brasileira, como por exemplo, Joaquim Gonçalves Ledo e o padre Januário da Cunha Barbosa, exercendo, respectivamente, as funções de primeiro grande vigilante e grande orador daquela loja maçônica, ambos redatores do Revérbero Constitucional Fluminense, com destacada atuação na defesa de um ideário mais liberal na construção do Brasil como Estado-Nação. Todos os três foram eleitos deputados para a Assembleia Constituinte e Legislativa do Brasil de $1823^{111}$.

O próprio Príncipe Regente, D. Pedro, iniciou-se na maçonaria a 02 de agosto de 1822 com o pseudônimo maçônico de Guatimozin e, por meio de uma manobra do grupo opositor aos Andradas, capitaneados por Joaquim Gonçalves Ledo, Januário da Cunha Barbosa, José Clemente Pereira e outros, o príncipe acabou tomando o lugar de Grão-Mestre de José Bonifácio, que ficou como Grão-Mestre adjunto. Depois desse episódio, as facções se extremaram e passaram a se hostilizar reciprocamente ainda mais, corroborando a dicotomia explicitada por Maria Lúcia Bastos Pereira das Neves ao antagonizar uma elite coimbrã e uma elite brasiliense.

Nessa ocasião, José Bonifácio, que exercia grande influência sobre o príncipe, deliberou afastá-lo do Grande Oriente e reunir em outra sociedade secreta os elementos que podiam apoiar suas ações em prol de uma independência que garantisse a preservação da unidade do Império, sob a forma de governo monárquico. Surgia, assim, o Apostolado, tendo José Bonifácio convencido D. Pedro a ingressar nos quadros daquela loja maçônica com o título de archonte-rei, a autoridade máxima na hierarquia da loja recém-criada. José Bonifácio ficaria com o posto de lugar-tenente. Aos 30 de outubro de 1822, D. Pedro manda suspender as atividades do Grande Oriente e passa a

\footnotetext{
111 "Projeto de Constituição no "Apostolado" e sua autoria" in Revista do Instituto Histórico e Geográfica Brasileiro - RIHGB, Volume LXXVII, $2^{\mathrm{a}}$ parte, p. 3-9.
} 
perseguir os seus membros sob a acusação de traição à pessoa do Príncipe, já então, imperante. O próprio Joaquim Gonçalves Ledo não chega a tomar assento na Assembleia Constituinte de 1823 por estar fora do país, aguardando o julgamento da Devassa instaurada contra si por conta dos seus escritos, acusando-o de conspiração contra o governo. O Apostolado continuou exercendo suas atividades políticas por mais um ano, até 16 de julho de 1823, quando teve o mesmo destino do Grande Oriente, tendo sua sede invadida por D. Pedro I, acompanhado da tropa imperial, por denúncia de que ali se tramava uma conjuração contra a pessoa do Imperador, culminando com a demissão, no dia seguinte, de José Bonifácio do cargo que ocupava no Ministério.

O editor da Revista do Instituto Histórico e Geográfico Brasileiro narra uma versão pitoresca sobre a possível autoria do projeto de Constituição, apresentado na sessão de 01 de setembro de 1823 da Assembleia Constituinte e Legislativa do Brasil, e que teria sido elaborado nas sessões do Apostolado. Com efeito, aduz que:

"quando D. Pedro invadiu a sede da sociedade, que estava em sessão plena, conta-se que arrebatou das mãos de Antônio Carlos, presidente da sessão, a urna em que aquele procurava guardar, na surpresa da investida imperial, certos papéis secretos"112.

Esta urna conteria os livros de atas e outros papéis do Apostolado e pertenceu por muitos anos à biblioteca particular de D. Pedro II, que acabou por doá-la ao Instituto Histórico e Geográfico Brasileiro antes de regressar a Portugal às vésperas da Proclamação da República.

O conhecimento das atas das Primeiras Palestras do Apostolado veio lançar mais luzes sobre um ponto obscuro da nossa história constitucional, qual o de saber a quem pertence a autoria do projeto de Constituição apresentado à Constituinte de 1823 . Segundo o editor da RIHGB, "aquelas atas demonstram que no Apostolado se elaborara

\footnotetext{
112 "Projeto de Constituição no "Apostolado" e sua autoria" in Revista do Instituto Histórico e Geográfica Brasileiro - RIHGB, Volume LXXVII, $2^{\mathrm{a}}$ parte, p. 3-9.
} 
o projeto e que Antônio Carlos era o seu relator"113, que teria ingressado nos quadros daquela sociedade secreta em 28 de janeiro, sob o pseudônimo de Falkland. A constituição nas referidas atas também tinha pseudônimo: era denominada de "Periódico". A Ata da Assembleia Geral do Apostolado de 22 de março de 1823 relata que se leram os trabalhos da comissão do Periódico, e "puseram-se em livre discussão os 16 artigos apresentados pelo camarada relator Antônio Carlos" ${ }^{, 14}$.

Não obstante o projeto de Constituição apresentado na Assembleia Constituinte e Legislativa do Brasil de 1823, na sessão de 01 de setembro, ter recebido a alcunha de "Projeto Antônio Carlos" em reforço das conclusões do editor da RIHGB e em homenagem ao seu relator, o fato é que o deputado paulista não redigiu o projeto sozinho, tendo sido auxiliado pelos demais membros da Comissão de Constituição e Justiça da Assembleia, os deputados Antônio Luiz Pereira da Cunha, Pedro de Araújo Lima, José Ricardo da Costa Aguiar, Manuel Ferreira da Câmara, Francisco Muniz Tavares e José Bonifácio de Andrada e Silva, ainda que seja forçoso reconhecer o protagonismo do relator na elaboração do projeto $^{115}$.

Atendendo ao chamado do editor da RIHGB, que incita o espírito do historiador constitucional para a análise das referidas Atas, passamos a investigar o seu conteúdo, bem como as atas da Assembleia Constituinte e Legislativa do Brasil de 1823. No entanto, diferentemente da proposta da Revista acima referida, o móvel que nos dirige não é o esclarecimento da autoria do projeto de Constituição e sim a compreensão dos sentidos de constituição em disputa naquele momento histórico.

\footnotetext{
113 "Projeto de Constituição no "Apostolado" e sua autoria" in Revista do Instituto Histórico e Geográfica Brasileiro - RIHGB, Volume LXXVII, $2^{\text {a }}$ parte, p. 3-9.

${ }^{114}$ Ib idem, p. 3-9.

${ }^{115}$ RODRIGUES, José Honório. A Assembleia Constituinte de 1823. Petrópolis: Editora Vozes, 1974.
} 


\subsection{CONSTITUIÇÃO COMO CONTRATO: O USO DA IDEIA DE PACTO SOCIAL}

\section{NOS DEBATES}

O "Projeto de Constituição para o Império do Brazil"116 em debate na Assembleia consistiria no maior e mais importante contrato firmado pelos brasileiros, pois a sociedade que iriam fundar envolvia uma imensa quantidade de contratantes, designados sob a rubrica de cidadãos e cujo objeto seriam os negócios do Estado. Mas não deixava de ser um contrato, instrumento com o qual já estavam mais ou menos familiarizados pelo comércio pujante que se desenvolveu no território brasileiro desde a época de colônia, mas, muito especialmente, depois da transferência da corte real de Portugal para o Brasil. E como não podiam firmá-lo pessoalmente todos os brasileiros, membros desta imensa sociedade, foram realizadas eleições dos seus representantes, que, munidos de procurações outorgadas por seus constituintes, reunidos em assembleia iriam produzir os termos deste contrato, designado por constituição.

Esta natureza da constituição fica muito clara nos debates em torno do conceito de pacto social ou contrato social, trazidos à baila na discussão do artigo 12 do referido projeto $^{117}$. É o que se depreende do discurso produzido por Francisco Carneiro, em que aduz que "a sociedade civil deve ser fundada em um contrato bilateral e recíproco, da mesma sorte que o são as sociedades mercantis e outras regularmente feitas entre os

\footnotetext{
116 "Projeto de Constituição para o Império do Brazil" in Annaes do Parlamento Brazileiro. Assembleia Constituinte. 1823. Tomo Sexto. Volume 5. Biblioteca Digital da Câmara dos Deputados. Centro de Documentação e Informação. Coordenação de Biblioteca. http://bd.camara.gov.br. Typografia do Imperial Instituto Artístico, rua primeiro de março n. 21, Rio de Janeiro, 1874, p. 6-16.

117 "Art. 12. Todo brasileiro pode ficar ou sair do império quando lhe convenha, levando consigo seus bens, contanto que satisfaça aos regulamentos policiais, os quais nunca se estenderão a denegar-se-lhes a saída" in Annaes do Parlamento Brazileiro. Assembleia Constituinte. 1823. Tomo Quinto. Volume 5. Biblioteca Digital da Câmara dos Deputados. Centro de Documentação e Informação. Coordenação de Biblioteca. http://bd.camara.gov.br. Typografia do Imperial Instituto Artístico, rua primeiro de março $\mathrm{n}$. 21, Rio de Janeiro, 1874, p. 7.
} 
indivíduos para os seus particulares negócios" ${ }^{\prime 18}$. O referido deputado define as obrigações deste contrato da seguinte forma:

“o governo, depositário dos poderes e força pública, garante a todos os cidadãos o gozo de suas vidas, de razoada liberdade, de propriedade e de quaisquer outros direitos que possam competir-lhes; e cada cidadão é obrigado a prestar em benefício público o emprego de suas faculdades físicas e morais, de sua propriedade e o risco de sua mesma vida"119.

Por isso mesmo Francisco Carneiro entende que deveriam ser marcadas muito claramente as condições de saída deste "negócio", ou desta "quebra do contrato", não admitindo uma ampla liberdade de emigração aos cidadãos em geral, tais quais os sócios de uma sociedade particular, que só poderiam deixar a empresa, se satisfeitas determinadas condições, de modo que "a mesma exceção deve ser aplicável à regra da liberdade da saída, posta aqui no contrato fundamental e constituição do Império" ${ }^{120}$ (destaquei).

Neste passo, oferece emenda para suprimir as palavras "os quais nunca se estenderão a denegar-se-lhe a saída", acrescentando em seu lugar os seguintes casos de exceções à liberdade de deixar o país: “ "1 de perturbação e crise pública; $2^{\circ}$ de guerra declarada ou defensiva ou ofensiva; $3^{\circ}$ de haver o cidadão cometido crime que deva expiar no território do império"121.

É interessante o discurso de Carneiro de Cunha, em apoio à doutrina do artigo 12, quando indaga aos seus pares se seriam obrigados a ficar no país, se, por hipótese, houvesse apenas dois partidos, "um que queria o absolutismo e o outro a democracia»"122, e, com os quais não concordassem. Percebem-se aqui os dois "monstros" que os deputados queriam evitar a todo custo: o absolutismo que

${ }^{118}$ Annaes do Parlamento Brazileiro. Assembleia Constituinte. 1823. Tomo Sexto. Volume 6. Biblioteca Digital da Câmara dos Deputados. Centro de Documentação e Informação. Coordenação de Biblioteca. http://bd.camara.gov.br. Typografia do Imperial Instituto Artístico, rua primeiro de março n. 21, Rio de Janeiro, 1874, p. 113.

${ }^{119} \mathrm{Ib}$ idem, p. 113.

${ }^{120} \mathrm{Ib}$ idem, p. 113.

${ }^{121}$ Ib idem, p. 113.

${ }^{122}$ Ib idem, p. 114. 
representava a opressão do passado colonial e a democracia, que conduziria o país à anarquia e à fragmentação, com a independência das províncias, à semelhança do que vinha ocorrendo com a América Espanhola, sob a influência dos Estados Unidos.

José da Silva Lisboa se posiciona na mesma linha de Francisco Carneiro, pretendendo a supressão da última linha do artigo em discussão, relativamente à impossibilidade de denegação da saída do país pelas autoridades policiais, "por conter uma indefinida liberdade pessoal de sair qualquer cidadão, porque até agora se não tem admitido em nação alguma""123. O futuro Visconde de Cairú cita "O Espírito das Leis" de Montesquieu para sustentar que o genuíno espírito de liberdade não se acorda com o capricho de uma liberdade extrema e, mais uma vez, invoca a natureza contratual do pacto social, para afirmar a existência de obrigações recíprocas entre súdito e soberano.

Com efeito, aduz que "o pacto social é contrato sinalagmático, em que o governo se obriga à proteção do súdito, e este se obriga à obediência e subordinação" ${ }^{124}$ e prossegue afirmando que a liberdade irrestrita de sair do país conferida ao súdito, "contém o arbitrário e absurdo de converter-se o contrato bilateral em unilateral"125, de sorte que o governo não poderia nunca deixar de dar proteção ao súdito, mas este poderia subtrair-se à devida obediência quando bem quisesse.

O conservadorismo de Silva Lisboa fica bastante evidente quando refere que as leis brasileiras já seriam muito liberais ao não permitir a prisão por dívida civil, porque Holanda, França e até na Inglaterra, “onde bem se entende e melhor se pratica a liberdade civil” ${ }^{126}$, permitem a prisão do devedor insolúvel, reservando-se a equidade da lei apenas para os falidos de boa-fé, que apresentassem seus livros de razão e as causas

\footnotetext{
${ }^{123}$ Annaes do Parlamento Brazileiro. Assembleia Constituinte. 1823. Tomo Sexto. Volume 6. Biblioteca Digital da Câmara dos Deputados. Centro de Documentação e Informação. Coordenação de Biblioteca. http://bd.camara.gov.br. Typografia do Imperial Instituto Artístico, rua primeiro de março n. 21, Rio de Janeiro, 1874, p. 114.

${ }^{124}$ Ib idem, p. 114.

${ }^{125} \mathrm{Ib}$ idem, p. 114

${ }^{126}$ Ib idem, p. 114.
} 
da falência. Aliás, lembra que a Inglaterra também vedava a emigração dos seus artistas e manufatureiros, proibindo ainda a saída dos seus marinheiros para a marinha americana, por ocasião da guerra de independência. Ele recorda também a legislação de Portugal, que, no tempo de guerra, proibia a saída dos cidadãos, sob pena de desnaturalização.

Antônio Carlos sustenta o artigo, porque sua "matéria é constitucional"127 e o direito de deixar o país consistiria em uma hipótese de exercício do direito da mais ampla liberdade pessoal, confirmando exatamente a bilateralidade e reciprocidade do contrato social, eis que, depois de deixar o país, já não poderia exigir o súdito a sua proteção. Carneiro de Campos adverte que, se fosse admitida a liberdade irrestrita de sair do país, o contrato social seria "leonino" $" 128$, porque quando a sociedade mais dele precisasse, não poderia exigir-lhe que ficasse e por ela lutasse. Henriques de Rezende sublinha o perigo do reconhecimento do direito de sair do império por via constitucional, porque "por um artigo constitucional nada se lhe pode opor"129.

Francisco Carneiro de Campos, José da Silva Lisboa e José Joaquim Carneiro de Campos, por um lado; Carneiro da Cunha e Antônio Carlos Ribeiro de Andrada Machado e Silva, por outro, no debate em torno da possibilidade de alguns "contratantes" deixaram o país, rescindindo o pacto social da constituição do Brasil como Estado e como Nação, expressavam o antagonismo de posições de um grupo mais conservador e outro mais liberal na elaboração desse contrato especial.

Mas antes da polêmica em torno da retirada de alguns sócios, a Assembleia se deparou com a questão do ingresso dos contratantes no pacto social do Brasil. Quem

\footnotetext{
${ }^{127}$ Annaes do Parlamento Brazileiro. Assembleia Constituinte. 1823. Tomo Sexto. Volume 6. Biblioteca Digital da Câmara dos Deputados. Centro de Documentação e Informação. Coordenação de Biblioteca. http://bd.camara.gov.br. Typografia do Imperial Instituto Artístico, rua primeiro de março n. 21, Rio de Janeiro, 1874, p. 115.

${ }_{128}$ Ib idem, p. 116.

${ }^{129} \mathrm{Ib}$ idem, p. 117.
} 
poderia integrar o contrato? A discussão do artigo $5^{\circ}$ do projeto de Constituição ${ }^{130}$ procurou marcar a diferença entre os membros da sociedade brasileira e os cidadãos brasileiros.

Logo no início do debate, o deputado França apresentou uma emenda, visando à inclusão da palavra "cidadãos" no referido artigo. Argumenta que os crioulos, filhos dos escravos, nascidos no Brasil, seriam brasileiros, mas não poderiam ser considerados membros da sociedade brasileira. A discussão para definir "o que é brasileiro e o que é cidadão brasileiro" ${ }^{\text {131 }}$, tal como assevera Araújo Lima, era necessária para declarar se todos os membros da sociedade brasileira seriam também cidadãos brasileiros ou se, pelo contrário, esta última qualidade seria privativa de uma classe, chamando-se o "resto" simplesmente brasileiros. Subjacente a este debate encontrava-se a concepção de liberdade e igualdade entre os "contratantes" no pacto social, que os representantes da nação iriam estabelecer por meio da constituição.

Francisco Carneiro apoia a emenda, indagando:

"os escravos e os estrangeiros se poderão entender membros no sentido deste Capítulo? Não, por certo... a Constituição não se encarregou desses, porque não entram no pacto social; vivem no meio da sociedade, mas rigorosamente não são partes integrantes dela, e os indígenas dos bosques, nem nela vivem, por assim dizer." 132 .

\footnotetext{
130 “Art. $5^{\circ}$. São brasileiros: I - Todos os homens livres habitantes no Brasil e nele nascidos; II - Todos os portugueses residentes no Brasil antes de 12 de Outubro de 1822; III - Os filhos de pais brasileiros nascidos em países estrangeiros, que vierem estabelecer domicílio no império; IV - Os filhos de pais brasileiros nascidos em países estrangeiros, que vierem estabelecer domicílio no império; V - Os filhos ilegítimos de mãe brasileira, que, tendo nascido em país estrangeiro, vierem estabelecer domicílio no império; VI - Os escravos que obtiverem carta de alforria; VII - Os filhos de estrangeiros nascidos no império, contanto que os pais não estejam em serviço de suas respectivas nações; VIII - Os estrangeiros naturalizados, qualquer que seja a sua religião." in Annaes do Parlamento Brazileiro. Assembleia Constituinte. 1823. Tomo Quinto. Volume 5. Biblioteca Digital da Câmara dos Deputados. Centro de Documentação e Informação. Coordenação de Biblioteca. http://bd.camara.gov.br. Typografia do Imperial Instituto Artístico, rua primeiro de março n. 21, Rio de Janeiro, 1874, p. 7.

${ }^{131}$ Annaes do Parlamento Brazileiro. Assembleia Constituinte. 1823. Tomo Quinto. Volume 5. Biblioteca Digital da Câmara dos Deputados. Centro de Documentação e Informação. Coordenação de Biblioteca. http://bd.camara.gov.br. Typografia do Imperial Instituto Artístico, rua primeiro de março n. 21, Rio de Janeiro, 1874, p. 180.

${ }^{132}$ Ib idem, p. 180.
} 
Para os deputados defensores desta emenda, o pacto social se constituía em um verdadeiro contrato firmado somente pelas pessoas dotadas de capacidade civil. Por consequência disso, estariam excluídos os escravos e os índios e, como se tratava de um contrato especial, destinado apenas aos brasileiros, dele também estariam excluídos os estrangeiros, ainda que dotados de capacidade civil.

Tal como na constituição de uma empresa, a "sociedade" contratada excluía estas pessoas incapazes, como se denota da seguinte passagem do discurso de Francisco Carneiro:

\begin{abstract}
"os que são meramente brasileiros e que não fazem parte da chamada sociedade civil, não têm direitos, senão os de mera proteção e a geral relação de humanidade. Nós vamos marcar os direitos e as relações dos que entram no pacto social e cujo todo compõe o corpo político"133.
\end{abstract}

A assertiva de que a diferenciação entre brasileiros e cidadãos brasileiros parecia estar relacionada à capacidade civil para o exercício e gozo de certos direitos civis e políticos, é comprovada pelo discurso proferido por Rocha Franco, na sessão do dia 25 de setembro, em continuação da discussão do artigo $5^{\circ}$ do projeto de Constituição. Com efeito, diz o referido deputado que:

\begin{abstract}
"ainda não se adotaram nomenclatura diferente para designar o sujeito que goza de uns ou de outros direitos; por isso entendo que devemos usar da palavra cidadão que os compreende todos, porque a todos têm direito qualquer membro da sociedade, ainda que lhe falte algum requisito para exercitá-los; e não demos a ideia de formar uma sociedade composta de cidadãos e não cidadãos; o que no sentido literal quer dizer de membros e não membros da sociedade, o que repugna"134.
\end{abstract}

Além disso, a assertiva acaba por se comprovar também com a aprovação da emenda proposta pelo deputado França. Em seguida, entrou em discussão o $\S^{\circ}$ do artigo $5^{\circ}$, que estabelecia a primeira hipótese de cidadãos brasileiros, quais sejam, "todos os homens livres habitantes no Brasil e nele nascidos", tendo sido apoiada a

${ }^{133}$ Annaes do Parlamento Brazileiro. Assembleia Constituinte. 1823. Tomo Quinto. Volume 5. Biblioteca Digital da Câmara dos Deputados. Centro de Documentação e Informação. Coordenação de Biblioteca. http://bd.camara.gov.br. Typografia do Imperial Instituto Artístico, rua primeiro de março n. 21, Rio de Janeiro, 1874, p. 180.

${ }^{134}$ Ib idem, p. 181. 
emenda oferecida na sessão anterior pelo Deputado Maia, para que se suprimisse a palavra "habitantes", pelas mesmas razões acima expendidas.

O deputado Arouche Rendon adverte desde logo a confusão que a Assembleia causou com a aprovação da emenda do deputado França, relativamente ao caput do artigo $5^{\circ}$, porquanto observa que a Comissão de Constituição se propusera a mostrar no artigo em discussão quem seriam os brasileiros e não os cidadãos brasileiros, cujas qualidades seriam marcadas nos artigos seguintes, seguindo-se uma regra de primeiro dispor sobre situações mais gerais, para em seguida ir descendo às minúcias das situações mais particulares.

Com efeito, assevera que todas as hipóteses descritas nos parágrafos que compõem o artigo $5^{\circ}$ e que agora entravam em discussão haveriam de sofrer mudanças, diante da aprovação da emenda do deputado França, de que fazia exemplo, desde logo, o $\S 1^{\circ}$ em discussão. Assim, não seria exato que todos os homens livres nascidos e habitantes no Brasil seriam cidadãos, como se dava com os índios, por exemplo. Ante a observação do deputado Arouche Rendon seguiram-se várias propostas de alteração da redação do aludido $\S 1^{\circ}$, como, por exemplo, uma apresentada pelo próprio França, nos seguintes termos: "todos os homens livres residentes no império e nele nascidos de pais brasileiros ou de portugueses residentes no mesmo império antes de 12 de Outubro de $1822^{\prime \prime 35}$ ou ainda aquela apresentada por Francisco Carneiro, nos seguintes termos "todas as pessoas livres nascidas no grêmio do império brasileiro" 136.

Aliás, esta última proposta, que, apesar de apoiada pelos deputados, ao final não foi aprovada, reforça ainda mais a conclusão havida anteriormente de que os deputados estavam pensando na elaboração de um verdadeiro contrato para a constituição de uma

\footnotetext{
${ }^{135}$ Annaes do Parlamento Brazileiro. Assembleia Constituinte. 1823. Tomo Quinto. Volume 5. Biblioteca Digital da Câmara dos Deputados. Centro de Documentação e Informação. Coordenação de Biblioteca. http://bd.camara.gov.br. Typografia do Imperial Instituto Artístico, rua primeiro de março n. 21, Rio de Janeiro, 1874, p. 185

${ }^{136}$ Ib idem, p. 185.
} 
sociedade, aos moldes daquelas mercantis, com a qual estavam mais ou menos familiarizados. A referência à agremiação do Brasil deixa isso muito claro e tenta contornar o imbróglio criado com a adição da palavra cidadão no caput do artigo, excluindo todos aqueles que dela não faziam parte, por não ter "capacidade civil", aquela palavra que ainda não havia sido inventada, como disse Rocha Franco na sessão anterior. Ao final, todas as propostas de emendas foram rejeitadas e o artigo foi aprovado tal como havia sido redigido pela Comissão de Constituição.

$\mathrm{Na}$ sessão do dia 26 de setembro discutiu-se o $\S 2^{\circ}$ do artigo $5^{\circ}$, segundo o qual deveriam ser considerados cidadãos brasileiros todos os portugueses residentes no Brasil antes de 12 de outubro de 1822, data da aclamação de D. Pedro como Imperador do Brasil e considerada pelos deputados o marco da independência brasileira.

Vários deputados fizeram pronunciamentos, trazendo à baila as razões pelas quais se deveriam ou não considerar brasileiros os portugueses. Assim, desde o requisito da fixação da residência, domicílio ou habitação depois da independência, passando pela adesão à causa da independência do Brasil, expressa ou tacitamente, excluindo aqueles que pegaram em arma contra os brasileiros, fossem portugueses ou mesmo brasileiros, como aqueles que continuaram a sustentar a causa de Portugal no Maranhão, Pará e o Rio Negro, até o juramento da Constituição, várias foram as propostas para melhorar a redação original do artigo, que, pretendendo marcar um divisor temporal para diferenciar brasileiros e portugueses, acabou deixando de fora importantes critérios complementares, como os deputados demonstraram no acirrado debate que se travou.

Pereira da Cunha, membro da Comissão de Constituição, explica que a Comissão teve em mente dois possíveis marcos temporais para fazer a aludida distinção: a primeira, que acabou sendo consagrada no projeto, foi a data da 
independência, ou seja, 12 de outubro de 1822; e a segunda, que correspondia à data da publicação da Constituição, que ele designa por "lei fundamental". Mas, persuadido pelas manifestações dos seus pares, reconhece que a data escolhida já não seria a mais apropriada, lembrando que em 18 de setembro de 1822 já se havia determinado, por decreto, que todo português europeu ou brasileiro que abraçasse o sistema de independência usasse um laço verde, como legenda e distintivo da qualidade de cidadão brasileiro, e que todos os outros saíssem do Império no tempo fixado pelo Decreto. Ainda depois disso houve novas determinações de D. Pedro I, por meio dos Decretos de 8 e 14 de Janeiro de 1823, estabelecendo que qualquer súdito de Portugal que viesse com a intenção de se estabelecer pacificamente no Brasil deveria prestar juramento de fidelidade à causa do Brasil perante a câmara da localidade do porto em que desembarcasse. Diante disso, assevera estar convencido que "seria mais político e coadunado à nossa situação assinalar para este fim a data em que foi sancionada a nossa constituição"137, a fim de que as pessoas pudessem livremente escolher jurar ou não a Constituição, adotando ou não o pacto social brasileiro e, por consequência, sendo considerados ou não cidadãos brasileiros.

O único deputado a defender a redação do parágrafo proposta pela comissão foi França, para quem a identidade cultural entre portugueses e brasileiros justificaria um tratamento igual entre eles, lançando-se "um véu sobre todos os feitos lusos brasileiros antes dissidentes da causa"138. Esta anistia também foi apoiada por Montesuma, porém, condicionada ao juramento da Constituição pelos portugueses pretendentes à condição de cidadão brasileiro. Para Carneiro da Cunha, "dos artigos do projeto que se tem

\footnotetext{
${ }^{137}$ Annaes do Parlamento Brazileiro. Assembleia Constituinte. 1823. Tomo Quinto. Volume 5. Biblioteca Digital da Câmara dos Deputados. Centro de Documentação e Informação. Coordenação de Biblioteca. http://bd.camara.gov.br. Typografia do Imperial Instituto Artístico, rua primeiro de março n. 21, Rio de Janeiro, 1874, p. 192.

${ }^{138}$ Ib idem, p. 190.
} 
discutido é este sem dúvida para mim o mais difícil"139, tendo, ao final da discussão, sido aprovada a proposta de emenda apresentada pelo deputado Lopes Gama, considerando cidadãos brasileiros, "todos os brasileiros domiciliados no Brasil antes de 12 de Outubro de 1822 que, expressa ou tacitamente, se houverem ligado à sociedade brasileira" 140 .

Na sessão do dia 6 de maio da Assembleia devem ser destacados também os discursos dos deputados Maia, Accioli, Muniz Tavares e Andrada Machado sobre o conceito de constituição como pacto social. Com efeito, o deputado Maia, português não nascido no Brasil, propõe uma consulta imperial sobre as bases em que se deveria assentar o pacto social futuro, a fim de evitar perda de tempo e também de se confirmar ou não a consagração de D. Pedro como Imperador do Brasil, a depender das bases por ele engendradas. Para o deputado constituinte, o discurso imperial, na sessão do dia 3 de maio, carregou implicitamente o direito de veto absoluto do imperador à Constituição feita pela Assembleia, motivada, segundo ele, pela dispensa do prévio juramento à Constituição, permitido pelas câmaras ao Imperador.

Maia sustenta que as partes contratantes deveriam previamente negociar as cláusulas desse pacto, a fim estabelecer sua vontade de firmá-lo ou não. Neste passo é que as bases constitucionais, já adotadas em Portugal, consubstanciavam importante documento prévio acerca das condições contratuais do estabelecimento desse pacto constitucional. Tendo em vista que a nação brasileira, antes de ser representada na Assembleia já tinha aceitado, aclamado, assistido à sagração e ouvido o juramento incondicional de D. Pedro como seu Imperador Constitucional, deveria reconhecer nele

\footnotetext{
${ }^{139}$ Annaes do Parlamento Brazileiro. Assembleia Constituinte. 1823. Tomo Quinto. Volume 5. Biblioteca Digital da Câmara dos Deputados. Centro de Documentação e Informação. Coordenação de Biblioteca. http://bd.camara.gov.br. Typografia do Imperial Instituto Artístico, rua primeiro de março n. 21, Rio de Janeiro, 1874, p. 188.

${ }^{140} \mathrm{Ib}$ idem, p. 190. A discussão na assembleia sobre o tratamento jurídico conferido ao português certamente é a fonte de inspiração para as disposições constitucionais a ela posteriores, desde aquela consagrada na Carta Constitucional de 1824, que retrata muito fielmente este debate, até a atual Constituição de 1988, que prevê o estatuto jurídico do português equiparado ao brasileiro.
} 
a condição de "um contratante de alta e reconhecida dignidade, que deve ser atendido e respeitado na organização da Constituição"141 para que declarasse "as condições com que quer entrar no pacto social" ${ }^{142}$ e, se não fossem justas e razoáveis, não seria doravante reconhecido como Imperador do Brasil.

Antônio Carlos diferencia legislação ordinária, legislação constituinte e pacto social, para concluir que o Brasil já havia constituído o seu pacto social com a aclamação de D. Pedro como seu Imperador e a divisão dos poderes, por meio da convocação da Assembleia Constituinte. Neste passo, a Constituição que estava sendo preparada restringir-se-ia a estabelecer a relação entre os poderes já divididos. A constituição antiga serviria de base à constituição escrita, razão pela qual não se havia falar de pedir bases ao Imperador. Nas palavras do próprio Antônio Carlos:

\begin{abstract}
“uma Constituição bem equilibrada é a Constituição que quer Sua Majestade; é a que nós queremos; não vamos confundir tudo, uma coisa é legislação ordinária, outra coisa, Sr. Presidente, é legislação constituinte e outra coisa é o pacto social. Constituição firma o pacto social, e é que marca as fórmulas do mesmo pacto social. Quando indivíduos dispersos se juntam para formar uma sociedade, cada um é juiz da sua ação; pode ou não entrar; para sua obrigação é necessário seu consentimento; a unanimidade, é, pois de necessidade nesta primeira associação; mas quando indivíduos que já se acham formando um pacto social, querem estabelecer a relação entre os poderes, sua quantidade, e andamento geral, então rege a pluralidade; mas não a pluralidade entre nós, Sr. Presidente, sim a pluralidade da nação. Quando, porém, a nação marcou as relações, e só se trata do andamento ordinário, decide a pluralidade da Assembleia" ${ }^{143}$.
\end{abstract}

Como se vê, o deputado sustenta que o pacto social firmado através da constituição pode ocorrer de três maneiras: pela unanimidade dos cidadãos, quando os indivíduos dispersos decidem deixar o estado de natureza em que se encontram e formar uma primeira associação; pela pluralidade da nação, quando estes indivíduos já vivem em sociedade, com um pacto social tacitamente estabelecido, e a constituição deverá

\footnotetext{
141 Annaes do Parlamento Brazileiro. Assembleia Constituinte. 1823. Tomo Primeiro. Volume 1. Biblioteca Digital da Câmara dos Deputados. Centro de Documentação e Informação. Coordenação de Biblioteca. http://bd.camara.gov.br. Typografia do Imperial Instituto Artístico, rua primeiro de março n. 21, Rio de Janeiro, 1874, p. 24.

${ }^{142} \mathrm{Ib}$ idem, p. 24.

${ }^{143} \mathrm{Ib}$ idem, p. 24.
} 
estabelecer a relação entre os poderes; e, finalmente, pela pluralidade de uma assembleia, quando este pacto social tácito já marcou as relações entre os poderes, devendo a constituição somente estabelecer o andamento ordinário dos negócios do Estado. Ou seja, Antônio Carlos não quer pedir as bases para o Imperador, porque as bases já são suficientemente conhecidas.

Não obstante a inexistência de uma constituição escrita, para ele o Brasil já tinha um pacto social tacitamente estabelecido, ou seja, uma constituição à moda antiga, inclusive com a separação dos poderes definida, restando tão somente à Assembleia a tarefa de organizar um documento escrito estabelecendo o andamento ordinário dos negócios do Estado através da legislação ${ }^{144}$. Neste ponto é forçoso concluir que o ilustre deputado paulista não consentia poderes constituintes à Assembleia, pelo menos até aquele momento, na medida mesmo em que defende que o pacto social já estaria firmado previamente, restando tão somente à Assembleia a tarefa de elaborar a legislação necessária para o andamento dos negócios do Estado.

Essa conclusão é corroborada pelo debate sobre a natureza da constituição como pacto social verificado na sessão do dia 22 de maio, em que novamente se colocam em campos adversários aqueles deputados, adeptos de uma corrente mais liberal, que defendiam uma liberdade ampla na formulação do pacto social, com uma igualdade entre os contratantes e aqueles deputados, adeptos de uma corrente mais conservadora, que restringiam a liberdade e igualdade nessa contratação.

Merece destaque o discurso proferido por Henriques de Rezende refutando o argumento de Antônio Carlos de que o Brasil já estaria constituído pela aclamação de D. Pedro como Imperador. Para ele, se admitida essa hipótese como verdadeira, a

\footnotetext{
${ }^{144}$ Rousseau sustenta que, pelo pacto social é conferida existência e vida ao corpo político, enquanto que a legislação conferia-lhe movimento e vontade. Cf. ROUSSEAU, Jean-Jacques. Do contrato social ou Princípios do Direito Público. Martin Claret, São Paulo, 2004, p. 47.
} 
conclusão inevitável é "que esta Assembleia não é constituinte" "145. Henriques de Rezende afirma que:

"uma nação só se constitui quando organiza o seu pacto social; na qual marca as condições debaixo das quais os homens cedem dos seus originários direitos e pelas quais se conhece as vantagens que eles tiram dessa sessão"146.

Não obstante reconhecer que a aclamação dos povos representou uma escolha pela monarquia como forma de governo, o deputado afirma que a aclamação foi levada a efeito sob a condição de "governar debaixo de uma Constituição". E arremata indagando:

\begin{abstract}
“quem há de fazer essa Constituição? Será o imperador como inculcava uma cláusula do decreto da convocação do conselho de estado, que diz - 'A constituição que eu jurei dar?' Não de certo. Quem a deve fazer? O parlamento inglês? Não. As cortes de Lisboa? As de Espanha? Pior um pouco. A assembleia brasiliense é quem deve fazer essa constituição" "147.
\end{abstract}

Antônio Carlos contesta a afirmação de Henriques de Rezende de que teria dito que, pelo fato da aclamação, já estivesse o Brasil constituído, afirmando que "disse sim, e repito outra vez, que achamos os alicerces lançados"148, que antes da convocação da Assembleia Constituinte "tinha a nação determinado por aclamação alguns pontos constitucionais" 149 , de que faz exemplo a monarquia constitucional como forma de governo. Afirma que "a nação tinha de fato dividido os poderes" ${ }^{150}$ razão pela qual não poderiam os constituintes concentrá-los, devendo a Assembleia limitar-se a "marcar as relações entre os poderes já divididos"151 e tudo o que ultrapassasse os limites do mandato constituinte não obrigaria a ninguém.

\footnotetext{
145 Annaes do Parlamento Brazileiro. Assembleia Constituinte. 1823. Tomo Primeiro. Volume 1. Biblioteca Digital da Câmara dos Deputados. Centro de Documentação e Informação. Coordenação de Biblioteca. http://bd.camara.gov.br. Typografia do Imperial Instituto Artístico, rua primeiro de março $\mathrm{n}$. 21, Rio de Janeiro, 1874, p. 94.

${ }_{146}$ Ib idem, p. 94.

${ }^{147} \mathrm{Ib}$ idem, p. 94.

148 Ib idem, p. 99.

${ }^{149}$ Ib idem, p. 99.

${ }^{150}$ Ib idem, p. 99.

${ }^{151}$ Ib idem, p. 99.
} 
Custódio Dias rotula Rodrigues de Carvalho, Costa Aguiar, Pereira da Cunha e Andrada Machado de "carcundas" e "escritores de embira", em "tramas de servilismo e adulação", afirmando não entender "os preopinantes, que parecem dizer estar já feita pela aclamação uma espécie de meia constituição"152, o que para ele constituiria verdadeira "heresia em política"153. Neste passo, Custódio Dias afirma que os constituintes somente é quem deveriam fazer a constituição toda e o Imperador não seria capaz de deixar de aceitá-la, pois esta seria a liberdade bem entendida desejada pela nação, baseada em uma "constituição prudente, justa, firme e moderada, sem a qual nunca poderá ser feliz"154.

Talvez a discussão sobre o projeto de anistia, que dominou a sessão do dia 22 de maio represente, melhor do que nenhuma outra, a oposição na Assembleia Geral Constituinte e Legislativa do Brasil, entre "corcundas" e "constitucionais". Estes dois vocábulos são analisados pela historiadora Lúcia Maria Bastos Pereira das Neves, que assevera que "uma dimensão inédita era introduzida na linguagem por meio de vocábulos que expressavam novos sentidos, adequados ao movimento liberal"155, os quais podiam ser agrupados em torno de quatro conceitos fundamentais: despotismo, liberalismo, constitucionalismo e separatismo, normalmente com sentidos antagônicos entre si.

Com efeito, o conceito de despotismo surgiu como a principal palavra negadora da liberdade, exprimindo uma ideia de poder ilimitado, baseado exclusivamente na vontade do soberano absoluto e independente de leis. A palavra mantém uma relação de proximidade com outros conceitos como tirania, arbitrariedade, poder absoluto, Antigo

152 Annaes do Parlamento Brazileiro. Assembleia Constituinte. 1823. Tomo Primeiro. Volume 1. Biblioteca Digital da Câmara dos Deputados. Centro de Documentação e Informação. Coordenação de Biblioteca. http://bd.camara.gov.br. Typografia do Imperial Instituto Artístico, rua primeiro de março $\mathrm{n}$. 21, Rio de Janeiro, 1874, p. 100.

${ }^{153} \mathrm{Ib}$ idem, p. 100.

${ }^{154} \mathrm{Ib}$ idem, p. 100.

155 NEVES, Lúcia Maria Bastos Pereira das. Corcundas e constitucionais: a cultura política da independência (1820-1822). Rio de Janeiro: REVAN: FAPERJ, 2003, p. 117. 
Regime, opressão, servilismo e escravidão, podendo verificar-se a associação destas ideias e palavras nos pronunciamentos dos deputados nos debates da Assembleia Constituinte de 1823 para justificar seus posicionamentos em contrariedade aos discursos dos seus adversários, como vimos destacando ao longo deste trabalho.

Um vocábulo associado a despotismo, que passou a designar certa concepção política contrária aos postulados do constitucionalismo, destaca-se pelo simbolismo do personagem a ele associado: o corcunda, ou seja, aquele que não é reto, aquele que anda curvado, conformado com o peso do jugo sofrido, carregando no próprio corpo um defeito que o caracteriza e o deforma.

A edição, em 1821, por José Joaquim Lopes de Lima, do “Dicionário corcundativo ou Explicação das frases dos Corcundas", impresso no Rio de Janeiro pela Imprensa Nacional, traz uma interessantíssima definição do termo corcunda, que merece ser transcrita em sua literalidade. Diz:

\begin{abstract}
"Palavra da moda; homem que, afeito e satisfeito com a carga do despotismo, se curva como o dromedário para recebê-la; e, trazendo esculpido no dorso o indelével ferrete do servilismo, tem contraído o hábito de não mais erguer a cabeça, recheada de estonteadas ideias de uma sórdida cobiça"156.
\end{abstract}

O termo corcunda alcançou uma ampla divulgação no vocabulário político de 1820 a 1823 por meio da imprensa. O Espelho, por exemplo, na edição $n^{\circ} 140$, de 21 de março de 1823, definia "carcunda" como a pessoa portadora de um defeito não apenas físico, mas também moral ${ }^{157}$.

Dessa forma, o termo servia para referir-se de maneira acintosa a todos os que estavam a serviço do ideário do Antigo Regime, contrários às ideias constitucionais das Cortes Soberanas de Lisboa e favoráveis ao absolutismo e que se curvavam, pois, servilmente, perante o despotismo. Os corcundas eram considerados anticonstitucionais,

\footnotetext{
156 Dicionário corcundativo ou Explicação das phrazes dos Corcundas. (Por José Joaquim Lopes de Lima). Rio de Janeiro: Imp. Nacional, 1821, p.5.

${ }^{157}$ O Espelho, $\mathrm{n}^{\circ}$ 140, 21 de março de 1823.
} 
revelando que a palavra anticonstitucional estava muito mais ligada a uma postura política e ideológica, do que propriamente relacionada à contrariedade dos preceitos e postulados constitucionais. Vale dizer, neste momento histórico, uma pessoa poderia ser anticonstitucional, mas não uma lei ou um ato normativo.

Vale destacar, mais uma vez, a diferença de sentidos na utilização destes termos dos dois lados do Atlântico no mundo luso-brasileiro. Com efeito, em Portugal, durante o primeiro triênio vintista, o despotismo era sempre associado às práticas de governo anteriores à Revolução do Porto de 1820. No Brasil, por sua vez, o conceito aplicou-se a duas situações diferentes.

Em primeiro lugar, ao longo do ano de 1821, o despotismo era associado aos atos praticados pelo governo no Rio de Janeiro e pelos governadores das capitanias. Em segundo lugar, depois do movimento constitucional de 1822, o termo passou a ser utilizado para designar as "atitudes despóticas" das Cortes de Lisboa em relação ao Brasil. A edição ${ }^{\circ} 1$ do Revérbero Constitucional Fluminense, de 28 de maio de 1822 , denunciava que as Cortes queriam:

\footnotetext{
"liberalismo para Portugal e despotismo para o Brasil!... ao elaborarem uma Constituição, alicerce do edifício liberal, expressavam aos portugueses o símbolo da ruína do Antigo Regime, do despotismo e da tirania, mas para o mundo brasileiro, a partir de 1822, suas medidas e decretos transformavam-se em opressoras e violadoras de seus direitos"158.
}

Invertiam-se os sentidos. As Cortes eram despóticas e atribuíam-se aos ideólogos dos princípios liberais as propostas tirânicas do Congresso português, que seriam os futuros motivos da miséria do Brasil. Paradoxalmente, para a elite intelectual e política do mundo brasileiro, a Constituição liberal que Portugal elaborava

\footnotetext{
${ }^{158}$ Revérbero Constitucional Fluminense. $\mathrm{n}^{\circ}$ 1, 28 de maio de 1822.
} 
restabelecia o tirânico despotismo contra o Brasil. Os periódicos da época cunharam a expressão "despotismo constitucional" ${ }^{159}$ para se referir a esse paradoxo.

De igual maneira em relação aos corcundas e ao "corcundismo". Com efeito, um folheto português editado em Lisboa em 1822 revelava a má aplicação desde nome alegórico, pois os verdadeiros corcundas "eram os que se diziam constitucionais, mas criticavam e insultavam a religião católica"160, tais como os alguns folhetistas que identificavam a igreja católica com o absolutismo.

Ao identificar as Cortes de Lisboa como anticonstitucionais, também os constituintes portugueses passaram a ser designados pela elite brasiliense (e também pela elite coimbrã) de corcundas. Aliás, mesmo entre os deputados constituintes brasileiros, em 1823, em várias ocasiões foi utilizado o termo corcunda para referir-se aos pares que defendiam a ideia de uma Assembleia Constituinte limitada, tal como se vê claramente nos debates travados durante a sessão do dia 22 de maio acerca do projeto de anistia.

Muito interessante é a receita de cura do corcundismo que um médico prescreve a três corcundas, encontrada em um folheto publicado em Lisboa com o seguinte título: "Diálogo entre um médico e três corcundas em que se fez o curativo, ficando inteiramente livres da horrenda Corcunda que tinham e a prudência do dito médico, com que os fez tornar arrependidos". Não bastasse o título descritivo do objeto do folheto, a alegoria do médico e da cura associa a concepção político-ideológica dos corcundas a uma enfermidade, uma moléstia, por assim dizer, não apenas do corpo, mas principalmente da alma, com forte conotação religiosa, eis que a verdadeira cura, a

\footnotetext{
${ }^{159}$ Cf. NEVES, Lúcia Maria Bastos Pereira das. Corcundas e constitucionais: a cultura política da independência (1820-1822). Rio de Janeiro: REVAN: FAPERJ, 2003.

${ }^{160}$ A corcundice explicada magistralmente, ou a resolução de dois problemas interessantes a respeito dos corcundas. (Por doutor Hipolyto Gamboa). Lisboa: Off. de Simão Thadeo Ferreira, 1822. Apud NEVES, Lúcia Maria Bastos Pereira das. Corcundas e constitucionais: a cultura política da independência (18201822). Rio de Janeiro: REVAN: FAPERJ, 2003, p. 134.
} 
conversão ao constitucionalismo, exige o arrependimento, como uma espécie de expiação dos pecados. Diz:

"nós corcundas até aqui, por interesse, hábito e ignorância, e agora arrependidos, contritos e regenerados na Constituição, protestamos de hoje em diante, ser verdadeiros constitucionais e amigos do rei e da Nação, e de obedecer às Cortes, e a el-rei constitucional, cumprindo as suas determinações, leis e decretos". 161

O despotismo das Cortes de Lisboa é relembrado por Alencar, na sessão do dia 17 de setembro, durante a discussão do artigo $2^{\circ}$ do projeto de Constituição, versando sobre a composição do território brasileiro, denotando ser o referido deputado adepto das lições de Rousseau sobre a ampla liberdade e igualdade dos contratantes na formulação do pacto social. Indaga o aludido deputado constituinte:

“quem nos disse que o Pará e Maranhão não queriam fazer parte do Império do Brazil? Porventura isso está decidido? Mas suponhamos por um momento que estas duas províncias, que não entraram no nosso pacto social, formam sua união à parte e nos dizem - nós queremos federação convosco para nossa maior segurança, porque temos direito para isso. - Poderíamos nós subjugálas? De certo que não" 162 .

Aduz que se aquelas províncias manifestassem o desejo de inteira união com o todo do império, mas por meio de federação, o Brasil não poderia virar-lhes as costas, sendo de rigor o respeito à liberdade dos povos. O contrário, aliás, também seria verdadeiro. "Se os povos disserem que não querem mais união com Portugal, mas que se não querem também reunir conosco, não os havemos de obrigar, que para isso não temos direito algum, ainda que tivéssemos força"163. Alencar finaliza seu discurso advertindo os pares de que as Cortes de Lisboa foram desacreditadas e tornaram-se

\footnotetext{
${ }^{161}$ Diálogo entre hum medico e três corcundas em que se fez o curativo, ficando inteiramente livres da horrenda Corcunda que tinham e a prudência do dito médico, com que os fez tornar arrependidos. (Por doutor Hipolyto Gamboa). Lisboa: Off. de J.F.M. de Campos, 1821, fl. 2. Apud NEVES, Lúcia Maria Bastos Pereira das. Corcundas e constitucionais: a cultura política da independência (1820-1822). Rio de Janeiro: REVAN: FAPERJ, 2003, p. 135.

${ }^{162}$ Annaes do Parlamento Brazileiro. Assembleia Constituinte. 1823. Tomo Quinto. Volume 5. Biblioteca Digital da Câmara dos Deputados. Centro de Documentação e Informação. Coordenação de Biblioteca. http://bd.camara.gov.br. Typografia do Imperial Instituto Artístico, rua primeiro de março n. 21, Rio de Janeiro, 1874, p. 120.

${ }^{163}$ Ib idem, p. 120.
} 
despóticas quando tentaram impor ao Brasil suas decisões, cujas deliberações, aliás, passaram ao largo da representação brasileira.

$\mathrm{O}$ artigo $2^{\circ}$, acima referido, gerou interessantes discussões sobre a forma de Estado que deveria ser adotada pelo Brasil com a independência de Portugal, ou seja, se deveria ser adotada a forma de Estado Unitário, consagrando a unidade e indivisibilidade do Império ou ainda a Federação ou Confederação, pressupondo a autonomia das Províncias, segundo o arcabouço teórico de que dispunham os deputados naquela altura. Para Carvalho e Mello, em discurso proferido na sessão do dia 18 de setembro, o pressuposto da federação seria a independência das províncias, o que viria de encontro à unidade e indivisibilidade do império (aliás, já aprovadas pela Assembleia no artigo $1^{\mathrm{o}}$ do projeto de Constituição), bem como ao regime de monarquiaconstitucional, ambos previamente definidos pela nação quando da aclamação de D. Pedro como Imperador do Brasil. Ademais disso, os poderes outorgados pelos constituintes aos representantes da nação marcavam previamente essa delimitação quanto à forma de Estado e de governo, que deveriam ser adotados para o Império do Brasil e tais poderes não foram, nem poderiam ser revogados, pois "o pacto social está celebrado aprovando-se e aclamando-se o Senhor D. Pedro I como Imperador" ${ }^{\text {"164 }}$.

Como se percebe, Carvalho e Mello adota um conceito de constituição como pacto social idêntico àquele preconizado por Andrada Machado, mencionado linhas atrás. Para ambos, se a constituição era o instrumento do pacto social e este já havia sido celebrado pelo Brasil antes mesmo da aprovação da Constituição escrita pela Assembleia Geral Constituinte e Legislativa de 1823, vigorava entre nós a constituição antiga e a liberdade e igualdade dos contratantes desse pacto era limitada.

\footnotetext{
${ }^{164}$ Annaes do Parlamento Brazileiro. Assembleia Constituinte. 1823. Tomo Quinto. Volume 5. Biblioteca Digital da Câmara dos Deputados. Centro de Documentação e Informação. Coordenação de Biblioteca. http://bd.camara.gov.br. Typografia do Imperial Instituto Artístico, rua primeiro de março n. 21, Rio de Janeiro, 1874, p. 129.
} 
Também era esse o entendimento de José da Silva Lisboa para quem, ao contrário do que sustentaram alguns deputados com base na justiça de uma Constituição liberal que a Assembleia pretendia elaborar, todas as províncias poderiam sim, ainda que pela força, ser obrigadas a aceitar a Constituição, não havendo para elas nenhuma liberdade "de querer ou não aderir à causa comum"165. O futuro Visconde de Cairú, que exercera, nos tempos de D. João, a função de censor régio, abominava as ideias de Rousseau, a quem, por mais de uma vez, se referiu pejorativamente por ocasião das sessões da Assembleia Geral Constituinte e Legislativa ${ }^{166}$. Neste passo, é compreensível que, para ele, as Províncias poderiam ser obrigadas, mesmo pela força, a aderirem ao pacto social.

É interessante como Silva Lisboa se vale de um argumento de garantia de direito fundamental para justificar a sua posição e demonstrar que as Províncias não tinham liberdade para aderir ou não ao pacto social, devendo submeter-se às decisões da Assembleia. Assim é que indaga:

\begin{abstract}
"suponha-se, por exemplo, que esta Assembleia decretava a abolição do tráfico da escravatura da África. Poderia a Bahia ou qualquer outra província, rebelar-se contra a decisão, e não ser esta executada com a força de lei, pelos pretextos que infelizmente aquela praça alegou atroando a Europa com a oposição à abolição do negro tráfico, aliás, reclamado pela justiça e causa da humanidade, que a Inglaterra e outras potências tanto promoviam?"167.
\end{abstract}

\footnotetext{
${ }^{165}$ Annaes do Parlamento Brazileiro. Assembleia Constituinte. 1823. Tomo Quinto. Volume 5. Biblioteca Digital da Câmara dos Deputados. Centro de Documentação e Informação. Coordenação de Biblioteca. http://bd.camara.gov.br. Typografia do Imperial Instituto Artístico, rua primeiro de março n. 21, Rio de Janeiro, 1874, p. 134.

${ }^{166}$ A título de exemplo, na sessão do dia 27 de outubro, ao defender o Rio de Janeiro como a melhor localidade para a instalação das Universidades que a Assembleia pretendia criar, enaltece o controle do governo sobre a qualidade dos cursos, particularmente, o curso jurídico, evitando a divulgação de ideais contrárias ao sistema de governo adotado no Brasil. Assim, indaga aos seus pares se "pode algum governo tolerar, que em quaisquer aulas se ensinem, por exemplo, as doutrinas do Contrato Social, do Sofista de Genebra, do Sistema da Natureza e da Filosofia da Natureza, de ímpios escritores, que têm corrompido a mocidade que forma a esperança da nação, para serem seus legisladores, magistrados, mestres e empregados na igreja e no estado?" e, enfaticamente, responde: “nunca, nunca, nunca”. Cf. Annaes do Parlamento Brazileiro. Assembleia Constituinte. 1823. Tomo Sexto. Volume 6. Biblioteca Digital da Câmara dos Deputados. Centro de Documentação e Informação. Coordenação de Biblioteca. http://bd.camara.gov.br. Typografia do Imperial Instituto Artístico, rua primeiro de março n. 21, Rio de Janeiro, 1874, p. 165.

${ }^{167}$ Annaes do Parlamento Brazileiro. Assembleia Constituinte. 1823. Tomo Quinto. Volume 5. Biblioteca Digital da Câmara dos Deputados. Centro de Documentação e Informação. Coordenação de Biblioteca.
} 
Foram raras as vezes em que a Assembleia trouxe à baila a questão do tráfico negreiro e durante praticamente toda a vigência do Império, até bem pouco tempo antes da Proclamação da República, quase na virada do Século, ninguém ousou tocar nesta pedra de toque da história brasileira. Porém, o argumento utilizado por José da Silva Lisboa só demonstra como muitas vezes a constituição é mobilizada contra ela própria $^{168}$, na medida em que, como instrumento destinado a assegurar a liberdade, no âmbito da independência do Brasil, tanto de indivíduos, como da nação e do Estado, era invocada para justificar uma posição que justamente eliminava essa liberdade, no caso, a das Províncias em aderir ou não ao pacto social.

Por fim, o deputado Alencar tenta mudar a cena do debate, evitando a palavra "federação" e oferecendo à mesa um aditamento à emenda do deputado França, para que a constituição não obrigasse às províncias do Pará, Rio Negro e Maranhão, enquanto não entrassem para a comunhão do Império do Brasil. O paradigma de Alencar para tal proposição foi, sem dúvida, o dispositivo constante nas bases da Constituição Portuguesa, que dispunha que a Constituição que seria elaborada pelas Cortes de Lisboa não obrigaria o Brasil, enquanto seus representantes não a aprovassem. Tal inspiração não passou despercebida por José da Silva Lisboa que, atacou a indicação feita por Alencar, aduzindo que não se podiam comparar as relações mantidas entre Portugal e Brasil, na condição de Reinos, com aquelas mantidas entre as províncias brasileiras, meras divisões administrativas do império. Ademais, lembra o desfecho dos procedimentos das Cortes de Lisboa em relação ao Brasil, que acabaram por fomentar o processo de independência brasileira e, se passasse a indicação de

http://bd.camara.gov.br. Typografia do Imperial Instituto Artístico, rua primeiro de março n. 21, Rio de Janeiro, 1874, p. 134.

${ }^{168}$ CARVALHO NETTO, Menelick de; SCOTTI, Guilherme. Os direitos fundamentais e a (in)certeza do direito - a produtividade das tensões principiológicas e a superação do sistema de regras. Editora Fórum, Belo Horizonte, 2011. 
Alencar, o mesmo poderia ocorrer com as províncias em relação ao resto do império, tal como vinha ocorrendo com as colônias espanholas.

O deputado Souza Mello fala em seguida, aduzindo que o aditamento proposto por Alencar seria inútil, pois para ele estava claro que, enquanto as províncias do Pará e do Maranhão (ele não menciona o Rio Negro, mas o raciocínio é o mesmo) não mandassem à Assembleia seus representantes, não ficariam sujeitas ao pacto social só por estarem nele mencionadas como parte do território do Brasil, o que só ocorreria com a adesão que manifestassem "ao mesmo pacto e à Constituição"169. Entretanto, a questão não era tão simples como queria fazer crer Souza Mello, porquanto envolvia, ainda que por vias transversas e evitando o uso da palavra federação, a possibilidade de algumas províncias do Brasil não aderirem à Constituição que estava sendo preparada pela Assembleia, reconhecendo-se, implicitamente, a possibilidade de se declararem independentes e adotarem cada qual a sua própria constituição, com forma e regime de governos próprios.

Por isso mesmo a disputa entre a ala mais liberal e a mais conservadora da Assembleia ainda continuaria, tendo Muniz Tavares, representante da primeira, apoiado a indicação feita por Alencar, aduzindo que "bastava o exemplo que sobre o mesmo objeto nos deram as Cortes de Portugal"170, que "depois de terem tomado uma resolução sobre as bases da Constituição portuguesa, disseram que nunca obrigariam o Brasil, porque não estavam ainda ali todos os seus representantes" ${ }^{\prime 17}$. Os deputados Rodrigues de Carvalho e Lopes da Gama sustentam o contrário, aduzindo, com Silva Lisboa, todos

\footnotetext{
${ }^{169}$ Annaes do Parlamento Brazileiro. Assembleia Constituinte. 1823. Tomo Quinto. Volume 5. Biblioteca Digital da Câmara dos Deputados. Centro de Documentação e Informação. Coordenação de Biblioteca. http://bd.camara.gov.br. Typografia do Imperial Instituto Artístico, rua primeiro de março n. 21, Rio de Janeiro, 1874, p. 135.

${ }^{170} \mathrm{Ib}$ idem, p. 136.

${ }^{171}$ Ib idem, p. 136.
} 
representantes da segunda corrente, que províncias não poderiam ser tratadas do mesmo modo que nações, de modo que o direito de independência a elas não se estenderia.

Por sua vez, Montesuma rebate este argumento, sustentando que, se o indivíduo tem o direito de se desnaturalizar quando não concordar com a Constituição do Império, da mesma forma o teria a província. Nesses termos, afirma:

"nós devemos considerar duas coisas: $1^{\text {a }}$ o caso de estar a nação constituída;
$2^{\mathrm{a}}$, o inverso, isto é, o de estar-se constituindo. Naquele caso alguns direitos
mais têm a maioria sobre a parte; neste, porém, nenhum"172 e complementa
"ainda não temos pacto de sociabilidade, ainda não somos nação no sentido
político e do direito das gentes"173.

Não obstante votar pelo artigo do modo como a comissão o redigiu, declarandose o Pará, Maranhão e Rio Negro como parte do império do Brasil, Nogueira da Gama assevera "ser princípio de direito público e universal que nenhuma povoação deve ser violentada a fazer parte de outra sociedade" ${ }^{174}$. Assim, se era certo que as províncias do Pará e Maranhão (não menciona o Rio Negro) ainda não tinham enviado representantes para a Assembleia, e, portanto, não haviam ainda formalmente aderido à causa do Brasil, igualmente indubitável era que este sentimento não era comum à integralidade daquelas províncias, havendo mesmo considerável parte da província do Maranhão que declarou sua independência de Portugal e união ao Império do Brasil e, no caso do Pará, a Assembleia já teria recebido emissários daquela província solicitando socorro aos oprimidos brasileiros, dando mostras, pois, que tinham a intenção de fazer causa comum à independência brasileira.

Montesuma rebate também o argumento de Nogueira Gama, asseverando que o dever de socorrer aquelas províncias não autorizava a Assembleia a obrigá-las a aceitar

\footnotetext{
${ }^{172}$ Annaes do Parlamento Brazileiro. Assembleia Constituinte. 1823. Tomo Quinto. Volume 5. Biblioteca Digital da Câmara dos Deputados. Centro de Documentação e Informação. Coordenação de Biblioteca. http://bd.camara.gov.br. Typografia do Imperial Instituto Artístico, rua primeiro de março n. 21, Rio de Janeiro, 1874, p. 137.

${ }_{173}$ Ib idem, p. 137.

${ }^{174}$ Ib idem, p. 138.
} 
a Constituição, do mesmo modo que a França não tinha o direito de obrigar os Estados Unidos a adotar as suas instituições políticas por ter-lhe prestado auxílio contra a Inglaterra na guerra de independência. Desse modo, sustentava que "todos nós temos o direito de aceitar ou deixar de aceitar a Constituição que a assembleia decretar" ${ }^{\text {175 }}$, sob o fundamento de que "os representantes de uma nação não têm arbítrio, têm razão; todo o poder público arbitrário é nulo; é despótico; é ilegítimo" ${ }^{\text {176. }}$

A concepção da constituição como pacto social reflete muito bem a dualidade ideológica entre os deputados, que assinalou os trabalhos da Assembleia Geral Constituinte e Legislativa de 1823. Não obstante isso, a maioria deles, senão todos, concordavam que este era o meio mais adequado para assegurar (e consolidar) a independência do Brasil.

\subsection{SUPREMACIA DA CONSTITUIÇÃO: ELEMENTOS DA DISCUSSÃO}

A discussão sobre a constituição como direito supremo também esteve presente nos debates da Assembleia Geral Constituinte e Legislativa. Entram aqui não apenas o reconhecimento da hierarquia normativa que a constituição ostentava frente ao restante do ordenamento jurídico, mas também as questões relacionadas ao par forma/conteúdo, que determinavam o modo de alteração das normas constitucionais.

Na já citada sessão do dia 6 de maio, retorquindo a alusão do deputado Maia ao fato de as câmaras do Brasil haverem dispensado o Imperador do juramento prévio à Constituição, Antônio Carlos afirma que tal desistência ocorreu porque se tratava de um juramento promissório, que podia recair sobre um fato torpe, como por exemplo, uma

\footnotetext{
${ }^{175}$ Annaes do Parlamento Brazileiro. Assembleia Constituinte. 1823. Tomo Quinto. Volume 5. Biblioteca Digital da Câmara dos Deputados. Centro de Documentação e Informação. Coordenação de Biblioteca. http://bd.camara.gov.br. Typografia do Imperial Instituto Artístico, rua primeiro de março n. 21, Rio de Janeiro, 1874, p. 139.

${ }^{176}$ Ib idem, p. 139.
} 
"Constituição indigna do Brasil", incapaz de fazer a felicidade da nação. O seu argumento foi que não era o juramento que sustentaria a legitimidade e bem aventurança do pacto social e sim o seu conteúdo, pois, tal como já havia sustentado anteriormente perante as Cortes de Lisboa, "ninguém se obriga por juramentos promissórios, e que eles eram contra os costumes; que era preciso conhecer-se a matéria sobre que cabe o juramento; e que quando se não conhece, jurar ou não jurar é o mesmo“177.

O episódio não deixa de ser uma reminiscência do juramento antecipado, feito por D. João VI, à Constituição que estava sendo elaborada pelas Cortes Gerais e Extraordinárias da Nação Portuguesa, por ocasião do seu regresso a Portugal. O juramento de uma Constituição futura não impediu posteriormente que o Rei dissolvesse as referidas Cortes. Assim, calcado na premissa da história como mestra da vida $^{178}$, Antônio Carlos mobilizou um argumento conteudístico para justificar a dispensa do juramento prévio por D. Pedro, a fim de evitar a repetição no Brasil do que ocorreu em Portugal. Não deixa de ser também o reconhecimento de que o conteúdo das normas constitucionais veiculadas na Constituição que seria elaborada pela Assembleia Constituinte Legislativa era mais importante do que a formalidade do juramento.

A discussão do projeto de anistia na sessão do dia 21 de maio provocou um intenso debate entre os parlamentares, merecendo destaque os discursos de José Martiniano de Alencar e de Antônio Carlos Ribeiro de Andrada Machado, respectivamente, a favor e contra a anistia. O primeiro postulava a concessão de anistia aos acusados de crimes de opinião. O segundo, por seu turno, sustentava que o projeto

\footnotetext{
177 Annaes do Parlamento Brazileiro. Assembleia Constituinte. 1823. Tomo Primeiro. Volume 1. Biblioteca Digital da Câmara dos Deputados. Centro de Documentação e Informação. Coordenação de Biblioteca. http://bd.camara.gov.br. Typografia do Imperial Instituto Artístico, rua primeiro de março $\mathrm{n}$. 21, Rio de Janeiro, 1874, p. 24.

${ }^{178}$ CATROGA, Fernando. Ainda será a história mestra da vida? Estudos Ibero-Americanos. PUCRS, Edição Especial, n. 2, p. 7-34, 2006. Ainda, do mesmo autor: Os passos do homem como restolho do tempo. Memória e fim do fim da história, $2^{\mathrm{a}}$ ed., Ed. Almedina, Coimbra, 2011.
} 
de anistia era nocivo ao Brasil por três razões: " $1^{\circ}$ é injusto em sua matéria e forma; $2^{\circ}$ porque é impolítico nas circunstâncias atuais; $3^{\circ}$ porque é perigoso pela discórdia, que tende a gerar entre a Assembleia e o Poder Executivo"179.

É interessante resgatar os argumentos expendidos por Antônio Carlos quanto aos vícios do projeto de anistia, porque a matéria nele versada escapava ao conteúdo das atribuições da Assembleia. Com efeito, não consistia em uma reforma legislativa indispensável e urgente e, menos ainda, em matéria constitucional. Assevera o relator do projeto de Constituição que:

\begin{abstract}
"fomos escolhidos para fazer uma constituição, e só para isso é que nos escolheram; somos uma convenção ad hoc, não uma legislatura comum; as necessidades, porém, do Brasil, fizeram que ensanchássemos, talvez com injustificável arbítrio, o poder que só nos pertencia, e que nos declarássemos competentes também para as reformas indispensáveis e urgentes, além da constituição. Ora, em que ramo destas nossas atribuições entrará o projeto de anistia? Certamente não se pode encartar em artigo constitucional" ${ }^{\prime 180}$.
\end{abstract}

O dilema em torno da esfera de atribuições da Assembleia Geral Constituinte e Legislativa de 1823 permaneceu vivo por muitas outras sessões. Com efeito, Antônio Carlos reconhece que a competência para legislar sobre as reformas indispensáveis e urgentes pode ter sido decorrência de um possível “injustificável arbítrio" dos congressistas, na medida em que teriam sido escolhidos para fazer uma constituição "e só pra isso é que nos escolheram", como pode se depreender do excerto acima colacionado.

Como observado no Capítulo anterior, os movimentos constitucionais que antecederam a convocação da Assembleia por D. Pedro reivindicavam, principalmente, uma centralidade a um Poder Legislativo genuinamente brasileiro, como forma de evitar não somente o despotismo do monarca, como reminiscência do período colonial, mas

\footnotetext{
179 Annaes do Parlamento Brazileiro. Assembleia Constituinte. 1823. Tomo Primeiro. Volume 1. Biblioteca Digital da Câmara dos Deputados. Centro de Documentação e Informação. Coordenação de Biblioteca. http://bd.camara.gov.br. Typografia do Imperial Instituto Artístico, rua primeiro de março $\mathrm{n}$. 21, Rio de Janeiro, 1874, p. 85.

${ }^{180}$ Ib idem, p. 86.
} 
também do próprio legislativo português, que, por meio das Cortes de Lisboa, pretendiam dispor sobre os interesses do Brasil à distância, desconhecendo as necessidades e particularidades locais e sem uma efetiva representação brasileira.

Neste passo, antes mesmo das funções constituintes da Assembleia brasileira, já estavam assentadas as suas funções legislativas, como asseverou Maria Beatriz Nizza para quem somente com o decreto de convocação por D. Pedro dissiparam-se as dúvidas acerca do alcance dos poderes da Assembleia. Legislativa antes de ser constituinte, não surpreende que os deputados disputassem o grau de importância das leis aprovadas pela Assembleia, chegando muitas vezes a colocar o projeto de Constituição em patamar inferior aos demais projetos.

Vale a pena trazer à baila um trecho do discurso proferido pelo deputado França na sessão do dia 29 de julho, em que se percebe claramente a incerteza sobre a linha demarcatória entre lei e constituição. Dizia o deputado:

“já que nós estamos autorizados por nossos constituintes para legislar, nem só o provarei a priori, porque tal foi a intenção do povo quando explicitamente nos nomeou para um congresso ou assembleia constituinte e legislativa; como a posteriori e pela razão da congruência, pois a constituição nada mais é que um sistema de princípios gerais de Direito convencional, que não podem ser observados senão mediante as Leis regulamentares que são a norma de se aplicarem aos casos práticos: e não poderíamos ser comissionados de fazer uma Constituição, sendo, aliás, inibidos de lhes fazer as leis, de que depende a sua conveniente prática". ${ }^{181}$

$\mathrm{O}$ fato de reunir funções tanto legislativas como constituintes não era propriamente uma novidade para os deputados da Assembleia de 1823, isto porque alguns deles já haviam exercido mandato perante as Cortes Gerais e Extraordinárias da Nação Portuguesa.

Na sessão do dia 26 de maio, por ocasião da discussão do projeto dos Governos das Províncias, os deputados Carneiro da Cunha e Costa Aguiar tangenciaram o

181 Annaes do Parlamento Brazileiro. Assembleia Constituinte. 1823. Tomo Terceiro. Volume 3. Biblioteca Digital da Câmara dos Deputados. Centro de Documentação e Informação. Coordenação de Biblioteca. http://bd.camara.gov.br. Typografia do Imperial Instituto Artístico, rua primeiro de março $n$. 21, Rio de Janeiro, 1874, p. 133. 
conceito de constituição como direito supremo. O primeiro sustenta que o projeto sobre o Governo das Províncias é de "tanta importância e interesse como o da constituição" ${ }^{182}$, razão pela qual se deveria esperar os deputados da Província da Bahia para a sua discussão, nos termos da proposta de Alencar. O segundo, por sua vez, refuta o argumento de que o projeto de governo das Províncias teria uma importância equiparada ao da Constituição, pois, para ele, enquanto a lei de governo das Províncias poderia ser facialmente alterada, por conta da sua condição de lei ordinária e, ainda por cima, provisória, “os artigos constitucionais não poderiam ser alterados ou reformados, senão pelo modo, forma, maneira e no tempo que na mesma constituição se marcar e determinar" ${ }^{\prime 183}$.

Importa considerar aqui mais os argumentos que ele não utilizou para distinguir tais situações, do que propriamente os utilizados. Com efeito, ainda que o projeto de lei de governo das Províncias fosse de inegável importância para a organização e administração dos governos regionais, Costa Aguiar percebeu uma supremacia das normas constitucionais sobre a lei ordinária. Para fundamentar sua posição, ele se vale de um argumento formal, relativamente à dificuldade de promover a alteração dos artigos constitucionais, comparativamente à legislação ordinária. Porém, o silêncio do argumento cessa na resposta à pergunta: porque as normas constitucionais eram mais difíceis de serem alteradas do que as demais normas jurídicas? Por serem hierarquicamente superiores. A supremacia da constituição não era desconhecida dos deputados. Ao contrário. Por várias vezes eles deixaram vir à tona a consciência dessa supremacia.

\footnotetext{
182 Annaes do Parlamento Brazileiro. Assembleia Constituinte. 1823. Tomo Primeiro. Volume 1. Biblioteca Digital da Câmara dos Deputados. Centro de Documentação e Informação. Coordenação de Biblioteca. http://bd.camara.gov.br. Typografia do Imperial Instituto Artístico, rua primeiro de março $\mathrm{n}$. 21, Rio de Janeiro, 1874, p. 115.

${ }^{183}$ Ib idem, p. 115.
} 
Voltando um pouco mais no tempo, as antigas Leis Fundamentais já eram consideradas como situadas em um nível mais elevado do que o das demais leis positivas humanas, inclusive no que tange à sua durabilidade e inquebrantabilidade, como ensina Airton Seelaender ${ }^{184}$, podendo, inclusive, em alguns casos, serem invocadas contra os próprios monarcas, para anular tudo o que o príncipe fizesse que as contrariassem. Nesse sentido, as leges fundamentales eram definidas como "meio de limitação do poder pelo direito positivo e núcleo da estrutura institucional do Estado", preparando o terreno para o desenvolvimento futuro do conceito moderno de constituição.

Vale dizer que, apesar disso, as Leis Fundamentais não podem ser consideradas como antecedente histórico necessário das constituições, tal como hoje as conhecemos. Isso porque elas não tinham o caráter de fundamento de validade do restante do ordenamento jurídico, nem tampouco refletiam preocupações com temas como a soberania popular, a tripartição dos poderes ou com o reconhecimento de direitos individuais. Enquanto a constituição moderna é entendida como um ato fundador do poder político e estabelece um rol de direitos individuais e garantia contra o Estado, a lex fundamentalis se voltava, sobretudo, à garantia do próprio Estado, cuja existência já era pressuposta ${ }^{185}$

O que se pretende realçar aqui é que os deputados da Assembleia Constituinte do Brasil de 1823 já dispunham de um instrumental teórico suficiente para alcançar a diferença entre uma norma constitucional e uma norma prevista em outros instrumentos normativos, fossem leis, decretos, regulamentos ou alvarás, reconhecendo a supremacia

\footnotetext{
${ }^{184}$ SEELAENDER, Airton Cerqueira-Leite. Lei fundamental. Construção, funções e impactos de um conceito do antigo regime. Biblioteca Digital Revista Brasileira de Estudos Constitucionais - RBEC. Belo Horizonte, ano 3, n. 11, jul/set. 2009.

185 Outras inúmeras diferenças poderiam ser apontadas, como a forma escrita e sistematizada, a organização do Estado e dos poderes, dentre outras, mas isso escaparia aos objetivos deste trabalho. Cf. SEELAENDER, Airton Cerqueira-Leite. Lei fundamental. Construção, funções e impactos de um conceito do antigo regime. Biblioteca Digital Revista Brasileira de Estudos Constitucionais - RBEC. Belo Horizonte, ano 3, n. 11, jul/set. 2009.
} 
da constituição em relação a todos os demais atos normativos. No entanto, a fim de defenderem posições políticas muito bem definidas, muitas vezes eles divergiram entre si, deixando de lado esta plêiade conceitual.

É precisamente este o caso do projeto de lei sobre o governo das Províncias. Tanto Carneiro da Cunha quanto Alencar, que defendiam a espera dos representantes das Províncias que ainda não haviam tomado assento na Assembleia, conheciam muito bem a supremacia da constituição relativamente ao mencionado projeto. Porém, defenderam uma equiparação de importância, com fulcro em um objetivo maior (para eles): assegurar uma representação geral da nação inteira como forma de legitimação do projeto. Ao passo que Costa Aguiar, que tinha interesse que o Rio de Janeiro ditasse as regras do jogo para todo o Brasil, já que era alinhado ao governo, sustenta a supremacia da constituição para possibilitar a votação do projeto de lei sobre o governo das Províncias o mais rápido possível. Vale destacar que o deputado Henriques de Rezende alcançou esse problema, ao menos em parte, ao afirmar que "a constituição é que deve

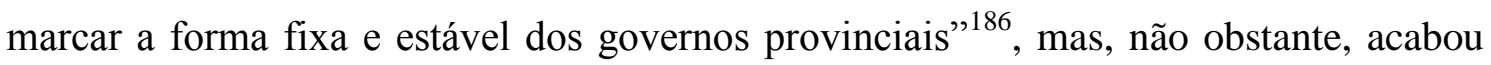
votando pela discussão e execução do projeto de lei.

No dia 1 de setembro, Antônio Carlos apresenta o projeto de Constituição ${ }^{187}$ elaborado pela Comissão de Constituição, contendo inúmeros dispositivos que acentuam a superioridade da constituição relativamente ao restante do ordenamento jurídico, notadamente os artigos constantes do Título XV, com a seguinte rubrica "do que é constitucional e sua revista”. Vale a pena transcrever dois importantes artigos, que

\footnotetext{
${ }^{186}$ Annaes do Parlamento Brazileiro. Assembleia Constituinte. 1823. Tomo Primeiro. Volume 1. Biblioteca Digital da Câmara dos Deputados. Centro de Documentação e Informação. Coordenação de Biblioteca. http://bd.camara.gov.br. Typografia do Imperial Instituto Artístico, rua primeiro de março $\mathrm{n}$. 21, Rio de Janeiro, 1874, p. 115.

187 "Projeto de Constituição para o Império do Brazil" in Annaes do Parlamento Brazileiro. Assembleia Constituinte. 1823. Tomo Quinto. Volume 5. Biblioteca Digital da Câmara dos Deputados. Centro de Documentação e Informação. Coordenação de Biblioteca. http://bd.camara.gov.br. Typografia do Imperial Instituto Artístico, rua primeiro de março n. 21, Rio de Janeiro, 1874, p. 6-16.
} 
posteriormente serão repetidos na Carta Constitucional outorgada por D. Pedro. Assim é que dispunham os artigos 267 e 268 do projeto de Constituição do Império do Brasil:

“Art. 267. É só constitucional o que diz respeito aos limites e atribuições
respectivas dos poderes políticos e aos direitos políticos e individuais.
Art. 268. Tudo o que não é constitucional pode ser alterado pelas legislaturas
ordinárias, concorrendo dois terços de cada uma das salas".

Os artigos 269 a 272 determinavam ainda o procedimento para a alteração das normas constitucionais. Com efeito, todas as vezes que três legislaturas consecutivas tivessem proferido um voto pelos dois terços de cada sala para a alteração de um artigo constitucional, teria lugar a revista da Constituição. Para tanto, seria expedido pelo Imperador um decreto de convocação de uma Assembleia exclusiva de revista, composta de apenas uma sala, com dois terços dos membros de ambas as salas e eleita como a sala dos deputados. A referida Assembleia de revista somente poderia se ocupar do objeto especificamente para o qual foi convocada e, findo o seu trabalho, dissolverse-ia de pleno direito.

A constituição como direito supremo decorria justamente desse caráter permanente das normas constitucionais, submetidas a um processo de alteração muito mais rigoroso e difícil do que aquele exigido para a mudanças das demais normas do ordenamento jurídico. Não obstante isso, importa destacar a disputa em torno do que seria essa constituição. Por isso mesmo é que, além dos artigos acima referidos, no projeto de Constituição elaborado pela Comissão de Constituição, era possível identificar normas como o artigo 13 que prescrevia que a restrição dos jurados em matérias cíveis "não forma artigo constitucional".

Ocorre que o artigo 267 do projeto de Constituição - e aqui está precisamente a sua novidade - cuidou de definir a natureza das normas constitucionais de acordo com o seu conteúdo, como sendo exclusivamente aquelas relacionadas aos limites e atribuições dos poderes políticos e aos direitos políticos e individuais dos cidadãos, exigindo tão 
somente para a alteração destas normas o procedimento legislativo especial acima referido. Desta sorte, o artigo 267 acabou por transportar para a forma do texto constitucional um elemento material de constituição.

Com efeito, a ideia de constituição em sentido material se associa ao intento de encontrar uma dimensão normativa anterior às normas estatais formalmente vigentes. Por este motivo, as doutrinas da constituição em sentido material são concebidas normalmente como a antítese das concepções positivas do direito e, em geral, de todas aquelas doutrinas que tendem a reduzir o direito, com a sua força cogente, às leis do Estado $^{188}$

O que importa acentuar para a compreensão do artigo 267 do projeto de Constituição da Assembleia Constituinte de 1823 é que os limites e atribuições dos poderes políticos e os direitos políticos e individuais dos cidadãos estavam carregados de historicismo, que ultrapassavam a sua identificação com um direito concebido pelo Estado, compreendendo uma ordem jurídica anterior de caráter objetivo. Os primeiros eram decorrentes da construção histórica da separação dos poderes como mecanismo de imposição de limites ao próprio poder, associado às transformações da monarquia absolutista em monarquia constitucional e república. Os segundos remontando aos direitos imemoriais reconhecidos desde a Magna Carta Inglesa. Todos eles guardavam entre si a semelhança de representarem uma reação ao despotismo, o tema mais caro a todos os deputados constituintes no processo de independência do Brasil.

Pelo fato de estabelecer um procedimento de reforma constitucional distinto para as normas definidas como materialmente constitucionais, mais complexo, dificultoso e com maiores exigências do que aquelas previstas para os demais dispositivos apenas

\footnotetext{
${ }^{188}$ FIORAVANTI, Maurizio. Las doctrinas de la Constitución em sentido material. Traducción del italiano de María Valvidares, Universidad de Oviedo. Fundamentos - Cuadernos monográficos de Tería del Estado, Derecho Público e Historia Constitucional (versão eletrônica), nº 6. Oviedo: Junta General del Principado de Asturias, 2010, p. 425-438. Disponível em http://www.unioviedo.es/constitucional/fundamentos/sexto/pdfs/10 fioravanti.pdf.
} 
formalmente constitucionais e para a legislação em geral, o projeto de Constituição elaborado pela Assembleia Constituinte poderia ser "classificada" como "semirrígida".

Além das Constituições dos Estados Unidos da América do Norte e da França, as experiências constitucionais de Cádiz, na Espanha, em 1812, as guerras por independência na América espanhola, que culminaram com a adoção de textos constitucionais entre 1810 e 1820 e a Constituição Portuguesa de 1822, compunham a parca literatura constitucional do período, de modo que uma interpretação possível é que os homens daquela época não sabiam bem ao certo o que eles tinham pela frente, quais eram, enfim, os limites e possibilidades de uma constituição e, por consequência disso, o que era ou não constitucional.

Outra hipótese é que no processo constituinte brasileiro predominou a busca por soluções negociadas, tendo sido conduzido muito mais fortemente pela habilidade política dos homens que engendraram o processo de independência do Brasil do que pelo confronto direto e armado, o que "desmistificava" de certo modo o papel da constituição como o instrumento consagrador daquela conquista, diferentemente do que ocorreu nos processos de independência que antecederam ao do Brasil. Com isso, talvez fosse diminuída ou "menosprezada" a importância da constituição, tornando desnecessário (ou até indesejável) o estabelecimento de uma rigorosa garantia de sua permanência, com um processo de alteração e reforma constitucional especialmente dificultoso e muito mais complexo do que aquele exigido para as reformas ordinárias da legislação. Sob esta ótica, ainda que a constituição fosse considerada uma lei especial em relação às demais, era ainda uma lei ${ }^{189}$.

O ineditismo do disposto no artigo 267 é revelado quando se comparam os textos constitucionais anteriores, que, de certo modo, serviram de modelo e inspiração

\footnotetext{
${ }^{189}$ Slemian, Andréa. Sob o império das leis: Constituição e unidade nacional na formação do Brasil (1822-1834). Tese apresentada para o Programa de Pós-Graduação em História Social para obtenção do título de Doutor. Universidade de São Paulo. São Paulo, 2006.
} 
Constituição dos Estados Unidos da América do Norte, nem a Constituições de 1791, 1793 e 1795 francesas, nem a Constituição de Cádiz de 1812 ou a portuguesa de 1822, que precederam o "Projeto Antônio Carlos" continham disposição semelhante. Arno Wehling defende que o referido projeto foi uma "compilação" de todas estas Constituições, contendo por isso, em todo o seu extenso corpo de texto, fragmentos de cada uma delas ${ }^{190}$.

$\mathrm{Na}$ verdade, uma análise mais atenta permite uma interpretação de que a fonte básica do aludido projeto foi mesmo a Constituição espanhola de Cádiz de 1812, que foi, por sua vez, em grande parte, reproduzida pela Constituição Portuguesa de 1822. E nenhuma delas previu algo sequer semelhante ao disposto no artigo 267 do projeto de Constituição apresentado pela Comissão de Constituição na sessão do dia 1 de setembro de 1823.

A Constituição de Cádiz ${ }^{191}$ previu um sofisticado processo de reforma do texto constitucional nos artigos 375 a 384, estabelecendo que durante os primeiros oito anos de vigência da Constituição, não se poderia propor alteração, adição, nem reforma alguma de seus artigos. Estabeleceu ainda que para haver qualquer alteração, adição ou reforma na Constituição, seria necessário que a deputação que haveria alterá-la definitivamente tivesse autorização com poderes especiais para tanto. Além disso, qualquer proposição de reforma de algum artigo constitucional deveria ser escrita e assinada por pelo menos vinte deputados. A proposição de reforma deveria ser lida por três vezes, com intervalo de seis dias entre cada leitura e depois da terceira leitura seria

\footnotetext{
${ }^{190}$ WEHLING, Arno. O Direito Constitucional como engenharia social no Brasil da independência. Métis: história\&cultura - v. 11, n. 21, p. 23-38, jan./jun. 2012.

${ }^{191}$ Constituição Política da Monarquia Hespanhola, promulgada em Cadiz em 19 de março de 1812, traduzida em português por A.M.F. Coimbra: Real Imprensa da Universidade, 1820.
} 
deliberado se seria admitida ou não a discussão da proposição de alteração, adição ou reforma da Constituição.

Uma vez discutida a proposição, dois terços dos deputados deveriam votar favoravelmente a que a deputação seguinte tivesse o direito de deliberar sobre a concessão ou não de poderes especiais de reforma da Constituição. Vale a pena destacar. Não se trata ainda aqui do direito de reforma propriamente dita, nem tampouco da concessão de poderes especiais de reforma. Na verdade, o que se tem nesta fase é a exigência de dois terços para que a deputação ou legislatura seguinte tivesse o direito de deliberar sobre a concessão dos poderes especiais de reforma.

Com efeito, a deputação geral seguinte poderia declarar em qualquer dos dois anos de suas sessões, por votos de dois terços dos deputados, a concessão de poderes especiais para se fazer a reforma constitucional. A declaração de concessão de poderes especiais seria publicada e comunicada a todas as Províncias e as Cortes decidiriam se as reformas seriam levadas a cabo na deputação proximamente imediata ou na seguinte. Os poderes especiais de reforma da Constituição seriam outorgados pelas Juntas Eleitorais de Província.

Finalmente, a proposta de reforma constitucional seria novamente submetida à discussão, exigindo-se para a sua aprovação, dois terços dos votos dos deputados eleitos com poderes especiais de reforma, passando a ser lei constitucional e publicada pelas Cortes. Uma deputação apresentaria o Decreto de reforma ao Rei para que o fizesse publicar e remeter para todas as autoridades e povos da Monarquia.

Neste passo, as exigências para uma reforma constitucional no sofisticado e complexo modelo espanhol consistiam na imutabilidade do texto durante os primeiros oitos anos de sua vigência e, depois, por proposta de pelo menos vinte deputados, seria submetida a três votações com exigência de quórum qualificado de dois terços dos 
deputados: a primeira para possibilitar à deputação seguinte a concessão de poderes especiais de reforma; a segunda, para a efetiva concessão desses poderes especiais e, por fim, a terceira, para a aprovação da reforma constitucional propriamente dita. O processo todo de reforma da Constituição poderia levar até quatro deputações ou legislaturas para ser concluído. Percebe-se, assim, a enorme dificuldade imposta para a efetivação de uma reforma constitucional. Ademais, nota-se também a ausência de qualquer dispositivo sequer semelhante com o contido no artigo 267 do projeto de Constituição da Assembleia Geral Constituinte e Legislativa do Brasil de 1823.

A Constituição Portuguesa de $1822^{192}$, cuja fonte imediata foi a Constituição de Cádiz, como afirmado anteriormente, também previu um processo de reforma constitucional, mais simplificado que o espanhol, porém ainda assim bastante rígido. Vale a pena uma observação: o processo de reforma constitucional é rígido e não a constituição em si mesmo considerada. A Constituição só poderia ser reformada ou alterada depois de haverem passados quatro anos, contados de sua publicação e, quanto aos artigos dependentes de lei regulamentadora, contados da publicação das referidas leis. Aqui já se pode notar uma diferença importante em relação ao modelo da Cádiz. O tempo de imutabilidade do texto reduziu-se pela metade.

A exigência de poderes especiais para a reforma constitucional foi reproduzida pela Constituição Portuguesa. Diversamente, porém, a Constituição de 1822 previu a exigência de votos de dois terços dos deputados presentes na sessão de votação para a concessão dos aludidos poderes, suprimindo também a necessidade de uma votação tão somente para admitir a possibilidade de concessão dos poderes especiais de reforma pela legislatura seguinte. Uma vez aprovada, a concessão dos poderes especiais seria reduzida a decreto, ordenando os eleitores dos deputados para a seguinte legislatura a

\footnotetext{
${ }^{192}$ Constituição Politica da Monarquia Portuguesa de 5 de outubro de 1822, transcrição feita de acordo com o original, atualizando a grafia (Luís Filipe Correia Henriques).
} 
conferir, nas procurações que lhes outorgassem, a especial faculdade para poderem fazer a pretendida alteração ou reforma, obrigando-se a reconhecê-la como constitucional no caso de chegar a ser aprovada.

A legislatura seguinte, munida das referidas procurações, iria discutir novamente a proposta, exigindo-se para a sua aprovação dois terços dos votos dos deputados, quando então seria havida como lei constitucional, incluída na Constituição e apresentada ao rei para fazê-la publicar e executar em toda a Monarquia. A Constituição dispensou expressamente a sanção real tanto em relação à sua própria aprovação, quanto com relação às alterações que nela se fizerem para o futuro.

O texto constitucional não é expresso, mas uma interpretação mais adequada parece ser aquela que exige a votação, para a aprovação da reforma constitucional, de dois terços dos deputados que compõe a Assembleia e não apenas dos presentes na sessão de discussão e votação, eis que, quando assim o quis, a Constituição foi expressa, como no caso da votação para concessão ou não de poderes especiais de reforma.

Como se pode ver, também na Constituição Portuguesa de 1822 não há nenhum dispositivo semelhante ao artigo 267 do "projeto Antônio Carlos". Neste passo, torna-se ainda mais interessante a investigação das razões pelas quais uma norma com tal foi pensada pelos seus autores. Um rastro importante são os próprios discursos dos deputados proferidos nas sessões da Assembleia em que o sentido da constituição como supremacia veio à tona.

Na sessão do dia 2 de setembro, a Assembleia determinou a distribuição de dois mil exemplares do projeto de Constituição para conhecimento dos povos, em um exercício daquela "pedagogia constitucional” já mencionada no Capítulo anterior. Após serem distribuídos os exemplares do projeto de Constituição e sido designada a data de 15 de setembro para o início das discussões, Antônio Carlos asseverou que cumpriria 
marcar a sua forma, já que, para ele, o regimento não seria aplicável ao caso, por não caber a primeira discussão, na medida em que não haveriam de tratar sobre a vantagem ou inutilidade do código constitucional e a terceira também não seria praticável, por ser impossível discutir o projeto de Constituição in globo e artigos por artigos a discussão seria eterna.

Assim, sugeriu que se adotasse o procedimento feito em Portugal, onde nunca houve mais que uma discussão, artigo por artigo, embora os deputados pudessem falar mais de três vezes. O deputado Nicoláo Pereira de Campos Vergueiro, identificado nas atas da Assembleia como Vergueiro, manifesta-se contrariamente à proposta de Antônio Carlos, aduzindo não the parecer coerente a exigência de três discussões para as leis regulamentares e somente uma para "a lei principal, a de maior proeminência"193.

Para Carneiro da Cunha era importante que a constituição refletisse a opinião geral e não somente a do Rio de Janeiro, razão pela qual não via problemas na possibilidade de mais de uma discussão para a aprovação do projeto de Constituição, argumentando, ainda, que muitos dos seus artigos haveriam de passar sem discussão, por derivarem de princípios justos e professados pelos povos. No mesmo sentido se manifesta José de Souza Mello, identificado nas atas da Assembleia como Souza Mello, para quem "o bom êxito das discussões e deliberações não consiste em se falar nelas muitas vezes, mas em se refletir maduramente pelos intervalos"194.

O deputado Alencar procura uma solução conciliatória, sustentando que não seria o caso mesmo de aplicação do regimento interno, porquanto este dizia respeito aos casos ordinários, excetuando-se, portanto, situações extraordinárias, como ocorreu com a aprovação do próprio regimento interno e como deveria ocorrer com a Constituição.

\footnotetext{
193 Annaes do Parlamento Brazileiro. Assembleia Constituinte. 1823. Tomo Quinto. Volume 5. Biblioteca Digital da Câmara dos Deputados. Centro de Documentação e Informação. Coordenação de Biblioteca. http://bd.camara.gov.br. Typografia do Imperial Instituto Artístico, rua primeiro de março n. 21, Rio de Janeiro, 1874, p. 53.

${ }^{194} \mathrm{Ib}$ idem, p. 76.
} 
Entre uma possível pecha de açodamento na aprovação da Constituição com uma única discussão, como pretendia a comissão e uma excessiva demora com a aplicação do regimento, como pretendiam alguns deputados, Alencar propõe que se ampliasse a possibilidade de revisão, prevista no parecer, para uma segunda discussão, o que, além de garantir maior amadurecimento para a tomada de decisão pelos deputados, conferiria maior legitimidade ao projeto, pois que já não seria obra de quatro ou cinco deputados, que formavam a maioria da comissão, mas da Assembleia como um todo, refletindo a voz da opinião pública.

É interessante mais uma vez notar aqui os silêncios, aquilo que não foi dito expressamente pelos deputados nesse debate sobre o modo de discutir e aprovar a Constituição. Percebe-se uma preocupação entre aqueles que se alinham na defesa do parecer da Comissão de Constituição, que reduzia a uma discussão única, com uma possibilidade de revisão, a forma de discutir e aprovar a Constituição: todos, sem exceção, referem-se à urgência da necessidade de uma constituição. José Bonifácio de Andrada e Silva, identificado nas atas da Assembleia como Andrada e Silva, afirma: “aprovo, portanto, o parecer, porque dá tempo suficiente para se deliberar com circunspecção e evita as demoras supérfluas a que nos levaria o regimento, quando tanto precisamos de constituição"195.

Há um ambiente político conflituoso no ar, revelado implicitamente neste debate, pois um grupo tão influente no processo de independência como foi o dos irmãos Andrada, participantes ativos das sociedades secretas, especificamente à maçonaria, como as lojas do Grande Oriente e do Apostolado, tinham sido afastados,

\footnotetext{
${ }^{195}$ Annaes do Parlamento Brazileiro. Assembleia Constituinte. 1823. Tomo Quinto. Volume 5. Biblioteca Digital da Câmara dos Deputados. Centro de Documentação e Informação. Coordenação de Biblioteca. http://bd.camara.gov.br. Typografia do Imperial Instituto Artístico, rua primeiro de março n. 21, Rio de Janeiro, 1874, p. 77.
} 
havia pouco tempo, do poder executivo pelo imperador, sendo certo que pressentiam uma tomada de atitude mais enérgica por parte de D. Pedro.

Muniz Tavares reforça esta conclusão ao opinar favoravelmente sobre o parecer da comissão, afirmando "praza a Deus que eu me engane, mas se não admitirmos o parecer da comissão, talvez chegue tempo de nos arrependermos de o não ter adotado"196. Do mesmo modo, José Ricardo da Costa Aguiar de Andrada, identificado nas atas da Assembleia como Costa Aguiar, defende o parecer da comissão, a qual pertencia, aduzindo que tanta demora traria desconfiança da nação às boas intenções da Assembleia, que, bem ou mal, durante todo este longo tempo, iriam continuar percebendo a quantia de $200 \$ 000$ réis mensais saídos dos cofres do tesouro do Império.

O pronunciamento final de Costa Aguiar não deixa mesmo sequer qualquer dúvida sobre o momento de tensão política vivido pelo Brasil, fazendo aumentar ainda mais a urgência da aprovação da Constituição, se bem que se referindo à política externa, diz:

\begin{abstract}
"permita-se senhores, ponderar, em último lugar, que nas circunstâncias atuais em que nos achamos, expostos à raiva e furor dos nossos inimigos, que não perdem um só momento para retardar o reconhecimento de nossa independência, nada há mais conducente para tão digno fim, como a ultimação do nosso pacto social e que este seja quanto antes sancionado e firmado... é do nosso interesse termos quanto antes uma constituição e isto quanto mesmo ela possa ter algum defeito, porque estes podem ser depois emendados pela experiência, que é a melhor mestra em tais matérias e, a meu ver, são males infinitamente muito menores do que aqueles que se nos podem seguir de não termos nenhuma" ${ }^{197}$.
\end{abstract}

Finalmente, no dia 15 de setembro teve início a discussão do projeto de Constituição, tendo os deputados debatido o preâmbulo, bem como o artigo $1^{\circ}$, com importantes discursos sobre a liberdade religiosa e ainda sobre as formas de governo. No entanto, a expressão "o Império do Brasil é um e indivisível” gerou bastante

\footnotetext{
${ }^{196}$ Annaes do Parlamento Brazileiro. Assembleia Constituinte. 1823. Tomo Quinto. Volume 5. Biblioteca Digital da Câmara dos Deputados. Centro de Documentação e Informação. Coordenação de Biblioteca. http://bd.camara.gov.br. Typografia do Imperial Instituto Artístico, rua primeiro de março n. 21, Rio de Janeiro, 1874, p. 77.

${ }^{197}$ Ib idem, p. 79.
} 
controvérsia, havendo mesmo quem defendesse a supressão total do artigo, como foi o caso do deputado Vergueiro.

Henriques de Rezende apoia essa proposta, mas acrescenta um fundamento importante do ponto de vista da teoria do direito constitucional. Com efeito, aduz que a referida expressão seria contraditória com a disposição constante no projeto, que permitia ao governo ceder ou trocar parte do império, desde que previamente autorizada pela própria Assembleia. Nestes termos, segundo ele, estando consagradas a unidade e indivisibilidade do território brasileiro por uma norma constitucional, a Assembleia jamais poderia autorizar a referida cessão ou troca, a não ser que houvesse uma reforma do referido dispositivo constitucional, para o que deveriam ser observadas as árduas exigências feitas pelos artigos 267 a 272 do projeto em discussão. Neste passo, assevera que a Constituição não deveria estabelecer a indivisibilidade do Império, de modo a possibilitar às legislaturas ordinárias a faculdade de aprovar ou não, uma eventual cessão ou troca pretendida pelo Imperador.

José Feliciano Fernandes Pinheiro, identificado nas atas da Assembleia como Fernandes Pinheiro, refuta a emenda apresentada por Vergueiro, considerando sofistas os argumentos utilizados pelo seu autor, na medida em que a unidade e indivisibilidade estabelecida no artigo diziam respeito à inalienabilidade do território brasileiro. No mesmo sentido Costa Barros, que explicita que a unidade e indivisibilidade previstas significavam que o Brasil seria submetido somente a uma e mesma lei. Igualmente, Ferreira Araújo também manifesta seu apoio ao artigo $1^{\circ}$, aduzindo que a indivisibilidade a que ele se referia era política e não física. Porém, aduz que a delimitação territorial não deveria fazer parte do artigo, "porque me parece que não é objeto constitucional" 198 .

\footnotetext{
${ }^{198}$ Annaes do Parlamento Brazileiro. Assembleia Constituinte. 1823. Tomo Quinto. Volume 5. Biblioteca Digital da Câmara dos Deputados. Centro de Documentação e Informação. Coordenação de Biblioteca.
} 
A discussão a respeito dos limites do território acabou por trazer à tona importantes argumentos de teoria política, com destaque para o sentido da forma e conteúdo das normas constitucionais. Neste passo, o deputado França defende que os limites geográficos do território não têm natureza de normas constitucionais, razão pela qual vota a favor da emenda supressiva, apresentada pelo deputado Vergueiro na sessão do dia 15 de setembro.

Também para Carvalho e Melo o estabelecimento de limites geográficos não constituía matéria a ser tratada na Constituição. Quanto à indivisibilidade do império, o referido deputado sustenta que os autores do projeto tiveram em vista decretar que por maneira alguma sofreria o império desmembramento, cessão ou alienação de alguma parte do seu território. Para ele, o epíteto usado foi inspirado "nas diversas constituições francesas" ${ }^{\prime 199}$, não havendo nenhuma contradição com outro capítulo do projeto sobre a divisão do império em províncias e distritos, porquanto tal divisão seria respeitante à administração interna e não propriamente à possibilidade de separação das várias partes componentes do Império.

A discussão do artigo $4^{\circ}$ do projeto de Constituição, havida na sessão do dia 20 de setembro, acerca da divisão do território do império em comarcas, distritos e termos, atendendo aos limites naturais e igualdade de população, gerou um debate interessante, que merece a nossa análise, porquanto, além das questões relacionadas à forma de organização do Estado, os deputados avançaram no tema da constituição como direito supremo.

http://bd.camara.gov.br. Typografia do Imperial Instituto Artístico, rua primeiro de março n. 21, Rio de Janeiro, 1874, p. 95.

${ }^{199}$ Annaes do Parlamento Brazileiro. Assembleia Constituinte. 1823. Tomo Quinto. Volume 5. Biblioteca Digital da Câmara dos Deputados. Centro de Documentação e Informação. Coordenação de Biblioteca. http://bd.camara.gov.br. Typografia do Imperial Instituto Artístico, rua primeiro de março n. 21, Rio de Janeiro, 1874, p. 114. 
Com efeito, Fernandes Pinheiro apoia o artigo originalmente proposto pela Comissão de Constituição, aduzindo que representava uma nova organização da administração, extinguindo "os vestígios de monumentos góticos de feudalismo",200, referindo-se à desigual partilha dos territórios pelas capitanias hereditárias. O deputado ainda lembra que a palavra província significava "país conquistado" e que um publicita da época, o conde de Languinais, autor das "Vistas políticas sobre a constituição de Hespanha", ensinava que "província era palavra que mal cabia em uma constituição livre"201. Propõe, por fim, que fosse suprimido o critério populacional para a divisão administrativa do território, porquanto a população do Brasil tenderia a aumentar, sendo inconveniente tratar do assunto por um artigo constitucional.

Avançando um pouco mais neste argumento, o deputado Maia defende a supressão do artigo, "por não ser a sua matéria constitucional, segundo o que está expressado no tít. 15, art. 267, onde se diz que é só constitucional o que diz respeito aos limites e atribuições respectivas dos poderes políticos e aos direitos políticos e individuais"202. E continua: "Porque, não sendo a matéria deste artigo de sua natureza constitucional, está ela sujeita a ser alterada pelas legislaturas ordinárias, como se declara no art. 268, e parece-me que esta assembleia deve ter toda a economia em não multiplicar artigos na constituição que possam sofrer alterações, como é este"203, tendo em vista a variação das circunstâncias de povoação que necessariamente haveria de ocorrer com o império do Brasil.

\footnotetext{
${ }^{200}$ Annaes do Parlamento Brazileiro. Assembleia Constituinte. 1823. Tomo Quinto. Volume 5. Biblioteca Digital da Câmara dos Deputados. Centro de Documentação e Informação. Coordenação de Biblioteca. http://bd.camara.gov.br. Typografia do Imperial Instituto Artístico, rua primeiro de março n. 21, Rio de Janeiro, 1874, p. 148.

${ }^{201} \mathrm{Ib}$ idem, p. 148.

${ }^{202} \mathrm{Ib}$ idem, p. 148.

${ }^{203}$ Ib idem, p. 148.
} 
Para Maciel da Costa, a marcação territorial do Império deveria sim ser tratada na Constituição, "porque é essencial e sem ela não pode marchar o governo"204, contudo, reconhece que esta divisão podia ser alterada com o tempo, por meio de uma lei regulamentar, tendo prevalecido, ao final, a sua emenda, proposta nos seguintes termos: "a Constituição mantém a divisão atual do território e para o futuro far-se-ão novas criações ou divisões, segundo pedir a necessidade do serviço ou o cômodo dos povos”205. Antes de Maciel da Costa, o deputado França sustentou que a matéria não deveria ser tratada na Constituição, deixando aos futuros legisladores toda a liberdade para irem dividindo progressivamente o território do império, segundo as circunstâncias de conveniência que a este respeito ocorrerem.

Vale destacar ainda o discurso de Montesuma pelas referências feitas às Constituições francesas de 1791, 1795 e 1799, além da Constituição de Cádiz de 1812 e à Constituição de Haia de 1815, como paradigmas a serem observados pelos deputados constituintes, seja para refutá-las, no caso das primeiras, seja para adotá-las como modelo, no caso das segundas. Contra a mudança da denominação de províncias para comarcas diz:

\begin{abstract}
“olhemos para a França e nela acharemos uma prova do quanto são efêmeras as divisões projetadas no calor das revoluções. A Constituição de $1791 \mathrm{fez} \mathrm{a}$ divisão de departamentos, distritos e cantões; daí a quatro anos ainda bem não estava realizada a divisão, já a Constituição de 95 dividiu os departamentos em cantões e estes em comunas. Em 99 aparece finalmente outra divisão de departamentos e arredondamentos de comunas" ${ }^{206}$.
\end{abstract}

E prossegue, elogiando a Constituição Espanhola e a Constituição de Haia de 1815: "prudentes foram os legisladores de Cádiz, que deixaram este objeto para quando

\footnotetext{
${ }^{204}$ Annaes do Parlamento Brazileiro. Assembleia Constituinte. 1823. Tomo Quinto. Volume 5. Biblioteca Digital da Câmara dos Deputados. Centro de Documentação e Informação. Coordenação de Biblioteca. http://bd.camara.gov.br. Typografia do Imperial Instituto Artístico, rua primeiro de março n. 21, Rio de Janeiro, 1874, p. 164.

${ }^{205} \mathrm{Ib}$ idem, p. 165.

${ }^{206} \mathrm{Ib}$ idem, p. 162.
} 
o permitissem as circunstâncias políticas da nação, como se vê do art. 11 da Constituição espanhola"207.

Um dos projetos de lei mais importantes discutidos pela Assembleia Geral Constituinte e Legislativa, no exercício de suas funções legislativas, versava sobre a vigência no Brasil de leis portuguesas após a declaração de independência, de autoria do deputado Pereira da Cunha. Com efeito, o parecer emitido pela comissão de Legislação conservava em inteiro vigor todas as leis, regimentos, alvarás, decretos e resoluções existentes, promulgados por D. João VI e pelas Cortes, desde que sancionadas por D. Pedro, e as promulgadas por ele até a data da instalação da Assembleia, "enquanto se não organizarem os novos códigos peculiares”. Por ocasião da segunda discussão do projeto, ficou decidida a elaboração, pela comissão de Legislação, de uma tabela de leis vigentes, que foi aprovada em 27 de setembro. O projeto foi aprovado e convertido na Lei de 20 de outubro de 1823, contendo a Tabela de leis vigentes, composta de 11 Decretos-Lei e 09 Cartas de Lei $^{208}$.

Arno Wehling enxerga na discussão do projeto de lei acima aludido um exemplo da contradição entre o novo e o velho, da confluência de dois mundos: o do Antigo Regime e o calcado em uma proposta constitucional. Para o autor, a aprovação do projeto de leis portuguesas vigentes no Brasil representa uma solução arcaizante que se contrapõe à supremacia da constituição como documento fundador do Estado e do direito. Mas era precisamente a indefinição semântica da constituição que possibilitava situações como essa. Wehling apreendeu muito bem essa fluidez ao destacar que nesse jogo de interesses que marcou o processo de independência do Brasil, "transigia-se com

\footnotetext{
${ }^{207}$ Annaes do Parlamento Brazileiro. Assembleia Constituinte. 1823. Tomo Quinto. Volume 5. Biblioteca Digital da Câmara dos Deputados. Centro de Documentação e Informação. Coordenação de Biblioteca. http://bd.camara.gov.br. Typografia do Imperial Instituto Artístico, rua primeiro de março n. 21, Rio de Janeiro, 1874, p. 162.

${ }^{208}$ Ib idem, p. 193-201, 220-227 e 254.
} 
as diferentes correntes de opinião e os interesses opostos, na busca de fórmulas que permitissem viabilizar, na prática, o constitucionalismo". ${ }^{209}$

Mas durante as discussões do referido projeto, o conceito de constituição como direito supremo foi invocado por vários deputados. Assim é que, na sessão do dia 24 de setembro, por exemplo, Vergueiro argumenta que a razão de a Assembleia ter admitido a vigência de leis que não foram feitas por ela é que, com a independência, o Brasil ficou automaticamente sem lei qualquer, já que se tratava da primeira reunião congressual brasileira. O fato é que o Brasil não podia conservar-se sem leis, razão pela qual se decidiu admitir aquelas que foram feitas pelas Cortes de Lisboa, desde que não se opusessem ao sistema constitucional adotado no país.

O discurso proferido por Pereira da Cunha revela o grau de consciência dos deputados constituintes sobre o alcance de significado dos conteúdos constitucionais que estavam a ser discutidos na Assembleia. Com efeito, o referido deputado, ao discorrer contra a inclusão na tabela de leis da Carta de Lei de 14 de outubro de 1822 , que dispunha sobre a inviolabilidade do domicílio, aduz que "não devemos envolver negócios constitucionais com os que pertencem meramente ao código civil",210, marcando claramente uma distinção de conteúdo entre normas constitucionais e normas legais.

O deputado Almeida e Albuquerque também demonstra que a formação jurídica obtida nos bancos da Universidade de Coimbra conferia aos constituintes uma plêiade de conceitos, que instrumentalizava os discursos proferidos na Assembleia para a defesa de suas posições. Neste passo, é digna de nota a sua opinião, no contexto da discussão

\footnotetext{
${ }^{209}$ WEHLING, Arno. O Direito Constitucional como engenharia social no Brasil da independência. Métis: história\&cultura - v. 11, n. 21, p. 23-38, jan./jun. 2012.

${ }^{210}$ Annaes do Parlamento Brazileiro. Assembleia Constituinte. 1823. Tomo Quinto. Volume 5. Biblioteca Digital da Câmara dos Deputados. Centro de Documentação e Informação. Coordenação de Biblioteca. http://bd.camara.gov.br. Typografia do Imperial Instituto Artístico, rua primeiro de março n. 21, Rio de Janeiro, 1874, p. 175.
} 
da formação da tabela de leis portuguesas vigentes no Brasil, em que discorre sobre as formas de interpretação das leis, afirmando que:

"quando se trata da inteligência de alguma lei, a primeira coisa a fazer é
examinar o espírito do legislador e ver qual é a razão da lei; é preciso não
tomar as palavras só no sentido literal, mas sim, combinar o subsequente com
o antecedente e acomodar sempre a inteligência ao fim e às razões do
legislador"211.

Com fulcro nesse entendimento, Almeida e Albuquerque sublinha que a razão de ser do decreto com a tabela das leis vigentes era justamente recepcionar as leis conformes aos princípios de justiça e ao sistema que o Brasil havia adotado, estabelecendo como marco temporal final a proclamação da independência, porque, dali em diante, as leis deveriam ser elaboradas pela própria Assembleia brasileira.

No mesmo sentido, Carneiro de Campos reitera o seu posicionamento externado na sessão do dia 22 de setembro, afirmando que, apesar de concordar com os bons termos da Carta de Lei de 14 de outubro de 1822:

"creio que não se pode estender além deste tempo (tempo da regência),
porque só neste tempo é que ainda formávamos uma nação com Portugal e,
portanto, só então é que essas leis se podem chamar nacionais; depois de
declarada a independência, já são estrangeiras todas as leis feitas pelas Cortes
de Portugal"212.

Toda a discussão girava em torno da emenda proposta por Antônio Carlos ao projeto de decreto originalmente proposto por Carneiro da Cunha. Com efeito, o autor do projeto referia-se expressamente às leis portuguesas que o então Príncipe Regente havia mandado executar, enquanto que a emenda possibilitava a adoção de qualquer lei que não fosse contrária aos princípios constitucionais adotados no Brasil. Ao final de muita discussão, acabou por prevalecer o entendimento que ultrapassava o limite temporal defendido por Almeida e Albuquerque e por Carneiro de Campos, tendo sido

\footnotetext{
${ }^{211}$ Annaes do Parlamento Brazileiro. Assembleia Constituinte. 1823. Tomo Quinto. Volume 5. Biblioteca Digital da Câmara dos Deputados. Centro de Documentação e Informação. Coordenação de Biblioteca. http://bd.camara.gov.br. Typografia do Imperial Instituto Artístico, rua primeiro de março n. 21, Rio de Janeiro, 1874, p. 176.

${ }^{212}$ Ib idem, p. 177.
} 
aprovada a inclusão da Carta de Lei de 14 de Outubro de 1822 na tabela de leis vigentes no Brasil, ainda que tenha sido promulgada pelas Cortes de Lisboa posteriormente à independência do Brasil, porque o conteúdo daquela norma, consagradora da inviolabilidade domiciliar, era consonante com os princípios constitucionais inscritos no projeto de Constituição em discussão.

Durante as discussões sobre os requisitos para a concessão da naturalização brasileira aos estrangeiros, alguns deputados sugeriram emendas para acrescentar alguns requisitos no artigo, como a condição de colono do estrangeiro ou o tempo de domicílio no país, para a concessão da carta de naturalização, mas, a isso se opôs o deputado França porque, segundo afirmou, "não posso convir em que se faça artigo constitucional de uma matéria que deve ser objeto de uma lei regulamentar" ${ }^{213}$. Não obstante isso, a matéria entrou em discussão. $\mathrm{O}$ deputado Vergueiro adere às críticas anteriormente formuladas por França e oferece emenda supressiva do artigo $6^{\circ}$, propondo a sua substituição por uma disposição genérica, estabelecendo que os requisitos e formas de naturalização seriam regulados por lei, porque, segundo ele, não se tratava de matéria constitucional.

Esse episódio foi abordado no tópico anterior, relativo ao conceito de constituição como pacto social, justamente porque, contrariando a proposta feita por Vergueiro, o deputado Carneiro de Campos sustenta que somente uma norma constitucional poderia conferir a segurança necessária aos estrangeiros imigrantes que pretendessem estabelecer-se no Brasil. Justamente porque eles não entravam no pacto originalmente, de modo que "uma lei regulamentar, sujeita por natureza a alterações,

\footnotetext{
${ }^{213}$ Annaes do Parlamento Brazileiro. Assembleia Constituinte. 1823. Tomo Sexto. Volume 6. Biblioteca Digital da Câmara dos Deputados. Centro de Documentação e Informação. Coordenação de Biblioteca. http://bd.camara.gov.br. Typografia do Imperial Instituto Artístico, rua primeiro de março n. 21, Rio de Janeiro, 1874, p. 6.
} 
não oferecesse uma garantia tão inabalável como um artigo da constituição"214, precisando de "uma segurança firme e imutável"215 para não verem malogrados seus projetos de imigração.

O Deputado França assevera não poder prescindir do estabelecimento dos requisitos essenciais para a naturalização na Constituição, porquanto "isso respeita à substância de uma posição, ou artigo constitucional... e não pode, como tal, deferir-se à autoridade de meros legisladores de uma lei regulamentar"216. O referido deputado associa a ideia de uma norma materialmente constitucional ao conteúdo por ela veiculado e estabelece, desde logo, uma hierarquia normativa entre as normas constantes em um artigo constitucional e àquelas veiculadas por uma mera lei regulamentar.

Como se vê, o debate girou em torno da natureza das disposições relativas à naturalização do estrangeiro, bem como da diferença de força normativa entre as normas veiculadas por lei regulamentar e aquelas integrantes da constituição, sendo certo que somente estas últimas teriam o condão de conferir "uma garantia inabalável, uma segurança firme e imutável”, próprias da estabilidade da forma constitucional, ao contrário das primeiras, cuja alteração obedeceria a um procedimento menos rigoroso do que aqueles previstos para a reforma das normas constitucionais e, por consequência disso, não garantiriam ao imigrante essa segurança.

Houve ainda quem pretendesse estender a concessão da naturalização aos estrangeiros perseguidos injustamente em seus países de origem, que viessem asilar-se no Brasil. Entretanto, José da Silva Lisboa assevera que os deputados estavam fazendo

\footnotetext{
${ }^{214}$ Annaes do Parlamento Brazileiro. Assembleia Constituinte. 1823. Tomo Sexto. Volume 6. Biblioteca Digital da Câmara dos Deputados. Centro de Documentação e Informação. Coordenação de Biblioteca. http://bd.camara.gov.br. Typografia do Imperial Instituto Artístico, rua primeiro de março n. 21, Rio de Janeiro, 1874, p. 16.

${ }_{215} \mathrm{Ib}$ idem, p. 16.

${ }^{216} \mathrm{Ib}$ idem, p. 17.
} 
confusão entre direito de asilo e direito de cidadão. Com efeito, para o futuro Visconde de Cairú a Constituição brasileira não negava o direito de asilo, franqueando a hospitalidade, o respeito aos direitos de humanidade e o exercício de indústria útil ao estrangeiro fugidio de sua pátria, mas isso não significava, em absoluto, a possibilidade de naturalização destes estrangeiros só por esse fato, pois:

\begin{abstract}
"isto, sendo estabelecido em constituição, é sem exemplo em nação alguma e destrói as bases do artigo constitucional, que requer nos estrangeiros, que se pretendem naturalizar, copulativamente, as condições de maioridade, domicílio e estabelecimento útil ao Brasil’²17.
\end{abstract}

Também neste caso, invocou-se a substância das matérias versadas nos artigos de uma constituição, para refutar a pretensão de concessão da naturalização aos estrangeiros perseguidos por opiniões políticas ou religiosas, constituindo-se em uma inovação destruidora das bases do artigo constitucional em discussão. Mas, não obstante isso, o próprio José da Silva Lisboa acaba por oferecer um exemplo em que se admitiu aquela naturalização. Trata-se do caso envolvendo Thomas Paine, que se viu processado pelo procurador da coroa da Inglaterra, em razão dos seus escritos sobre as formas de governo e que, por isso, acabou fugindo para a França, ainda no princípio da Revolução daquele país, onde foi, segundo Silva Lisboa:

\footnotetext{
"naturalizado pela assembleia, como perseguido por sustentar os direitos do homem e até lhe deram um lugar de deputado; sendo depois na mesma assembleia tratado por idiota e preso para ir à guilhotina, por ter sido um dos deputados contra a facção de Robespierre e teria igual fado se este não fosse destruído" 218 .
}

Outro tema que envolveu a discussão sobre a natureza das normas constitucionais e, por consequência, o reconhecimento da constituição como direito supremo, foi a liberdade religiosa. A discussão do artigo $7^{\circ}, \S 3^{\circ}$ ocupou praticamente

\footnotetext{
217 Annaes do Parlamento Brazileiro. Assembleia Constituinte. 1823. Tomo Sexto. Volume 6. Biblioteca Digital da Câmara dos Deputados. Centro de Documentação e Informação. Coordenação de Biblioteca. http://bd.camara.gov.br. Typografia do Imperial Instituto Artístico, rua primeiro de março n. 21, Rio de Janeiro, 1874, p. 17.

${ }^{218}$ Ib idem, p. 18.
} 
toda a sessão do dia 8 de outubro, mobilizando o discurso de vários deputados, uns contra, outros a favor, da liberdade religiosa consagrada no artigo em questão.

O deputado Rodrigues da Costa, cabeça da igreja diocesana do Rio de Janeiro, sustenta que "estabelecer-se entre nós como artigo constitucional uma tal liberdade muito me tem escandalizado",219, pois "os nossos constituintes, ou antes, quando a nação nos elegeu para seus representantes e depositou em nossas mãos a autoridade, foi na consideração de que não só sustentaríamos os seus direitos, mas que faríamos a sua felicidade", o que, para o deputado, afastava qualquer possibilidade de reconhecimento da liberdade religiosa, na medida em que o Brasil e os brasileiros adotaram a religião católica apostólica romana como religião oficial do Império, tendo, inclusive, os deputados prestado juramento de sustentar e defender essa mesma religião.

Por sua vez, Muniz Tavares diz falar como político e não como teólogo, reputando "a liberdade religiosa um dos direitos mais sagrados que pode ter o homem na sociedade" 220 , razão pela qual não admite que ninguém seja perseguido por sua profissão de fé religiosa, seja ele estrangeiro, como já admitido pela Assembleia ao franquear a naturalização ao estrangeiro independentemente de sua religião, seja ele brasileiro de nascimento. Ademais, refuta o argumento de Rodrigues da Costa de que a aprovação do artigo constituir-se-ia em apostasia, porque o juramento de manter a religião católica como religião do estado estava mantida pelo disposto no artigo 16 do projeto de Constituição em debate.

José da Silva Lisboa, por sua vez, ataca veementemente o artigo em discussão, aduzindo que a expressão "liberdade religiosa" seria indiferente em uma obra literária, como algum título de algum capítulo, em que o escritor tratasse de expor a sua definição

\footnotetext{
${ }^{219}$ Annaes do Parlamento Brazileiro. Assembleia Constituinte. 1823. Tomo Sexto. Volume 6. Biblioteca Digital da Câmara dos Deputados. Centro de Documentação e Informação. Coordenação de Biblioteca. http://bd.camara.gov.br. Typografia do Imperial Instituto Artístico, rua primeiro de março n. 21, Rio de Janeiro, 1874, p. 43.

${ }^{220} \mathrm{Ib}$ idem, p. 44.
} 
e limitação, porém, jamais "sendo posta em um projeto de constituição",221, sendo incompatível com o juramento feito pelos deputados de guardar a religião católica apostólica romana. Não se tratava simplesmente de uma questão de nome, porque "em tal matéria, os nomes também são de grande importância e estão tão ligados com a substância das coisas, que não se podem separar" ${ }^{222}$ e a proposta da comissão pecava pela imprudência de sua "infeliz originalidade"223, já que a liberdade religiosa, tal como proclamada no artigo em discussão, não era prevista “em constituição alguma de grande nação"224, sendo antes "liberdade de perjúrio e liberdade de apostasia ${ }^{225 "}$.

Não é indiferente que um homem tão esclarecido como José da Silva Lisboa refutasse com veemência a previsão da liberdade religiosa como norma constitucional. A estabilidade da forma constitucional não era desconhecida do futuro Visconde de Cairú, razão pela qual tentou, a todo custo, "proteger" a religião católica da Constituição. Essa oposição entre religião católica, liberdade religiosa e constituição representa mais um capítulo da crise de legitimidade da Assembleia, que justificaria algumas semanas depois a sua dissolução.

Silva Lisboa procura diferenciar a liberdade religiosa da liberdade de consciência, sustentando que esta última não era objeto de controle pelo Estado, mas tão somente os atos externos relativos ao culto público, razão pela qual os deputados não poderiam consagrar a primeira na Constituição "sem mandato expresso da nação e ainda nem tácito ou presumido dos nossos constituintes provinciais"226. Mobilizando um discurso do medo, aliás, recorrente nos debates da Assembleia em diversos assuntos, o

\footnotetext{
${ }^{221}$ Annaes do Parlamento Brazileiro. Assembleia Constituinte. 1823. Tomo Sexto. Volume 6. Biblioteca Digital da Câmara dos Deputados. Centro de Documentação e Informação. Coordenação de Biblioteca. http://bd.camara.gov.br. Typografia do Imperial Instituto Artístico, rua primeiro de março n. 21, Rio de Janeiro, 1874, p. 46.

${ }^{222} \mathrm{Ib}$ idem, p. 46.

${ }^{223} \mathrm{Ib}$ idem, p. 46.

${ }^{224} \mathrm{Ib}$ idem, p. 46.

${ }^{225} \mathrm{Ib}$ idem, p. 47.

${ }^{226} \mathrm{Ib}$ idem, p. 47.
} 
futuro Visconde de Cairú lembra o exemplo da França, em que a tolerância religiosa favoreceu os horrores da guilhotina, pois "os cabalistas abusaram logo das sucessivas concessões da tolerância e derribaram o governo estabelecido e as suas próprias novas

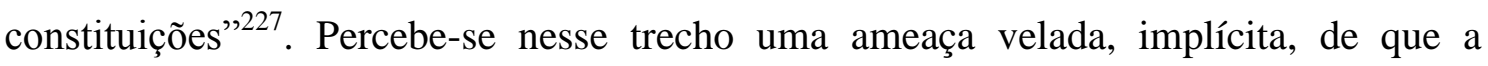
aprovação da liberdade religiosa, tal como prevista no projeto de Constituição, colocaria em risco a própria Constituição, que poderia ser derrubada, tal como ocorrera em França.

Aliás, José da Silva Lisboa ainda desdenha da Constituição Francesa, referindose a ela com sarcasmo ao advertir que elas eram "cheias de declarações de direitos do homem e de liberdades na administração e religião"228 e nem por isso deixaram de ser derrubadas. Para ele, a tolerância das "seitas" só seria de racional política a respeito dos estrangeiros, quanto a gozarem direitos cívicos, porque convinha atrair os industriosos e capitalistas de todas as nações ao Brasil, mas não aos brasileiros, que só alimentaria a cizânia entre os nacionais.

O deputado Francisco Carneiro de Campos, identificado nas atas da Assembleia como Francisco Carneiro, intervém no debate para defender a liberdade religiosa, asseverando ser a questão politica e não teológica, estando persuadido "que este parágrafo é um dos que mais honra fazem aos ilustres redatores do projeto de Constituição" 229 , pois a Constituição deveria "garantir a tranquilidade e liberdade dos cultos religiosos" 230 . Sustenta que, como foi aprovado o reconhecimento do direito de cidadania ao estrangeiro naturalizado brasileiro, qualquer que fosse a sua religião, não seria possível negar esse mesmo direito de professar a religião dos seus pais, aos filhos

\footnotetext{
${ }^{227}$ Annaes do Parlamento Brazileiro. Assembleia Constituinte. 1823. Tomo Sexto. Volume 6. Biblioteca Digital da Câmara dos Deputados. Centro de Documentação e Informação. Coordenação de Biblioteca. http://bd.camara.gov.br. Typografia do Imperial Instituto Artístico, rua primeiro de março n. 21, Rio de Janeiro, 1874, p. 47.

${ }^{228}$ Ib idem, p. 47.

${ }^{229} \mathrm{Ib}$ idem, p. 48.

${ }^{230}$ Ib idem, p. 48.
} 
destes nascidos no Brasil. E se a liberdade religiosa foi reconhecida aos estrangeiros, como haveria razão para não reconhecê-la aos brasileiros? Ademais, sustenta que a liberdade política da religião e do culto seria conforme a opinião das nações mais ilustradas, sendo praticada na Inglaterra, Países Baixos, França e Estados Unidos e até mesmo em Portugal, não podendo os deputados ser "menos justos e menos liberais do que foram os portugueses em tempos chamados escuros",231.

No mesmo sentido, Carneiro de Campos também defende a liberdade religiosa, advertindo não tratar da matéria como teólogo, como sim como publicista:

\begin{abstract}
"tendo unicamente em vista garantir a cada um dos nossos concidadãos os seus direitos, tanto quanto forem compatíveis com a segurança e felicidade geral de todos, pois são estas as duas incógnitas do grande problema da constituição dos povos... para ser livre, não basta que a pessoa e os bens do cidadão estejam defendidos e seguros da opressão; é também necessário que o seu espírito desembaraçado das cadeias da tirania, possa seguir em liberdade as ideias que ele julga verdadeiras, úteis e necessárias à sua felicidade" 232 .
\end{abstract}

O deputado França aduz que havia proposto uma emenda supressiva do artigo $7^{\mathrm{o}}, \S 3^{\circ}$, sobre a liberdade religiosa, porque "na verdade bem estranho me parece ser de uma constituição o tratar-se nela de coisas do outro mundo"233, sendo certo que, as questões de religião nunca teriam lugar nas assembleias políticas se não tivesse se desvirtuado para a tirania, como nos tribunais do santo ofício. No entanto, como sua emenda não foi apoiada, defendia que o artigo devia ser aprovado tal como redigido pela Comissão de Constituição, porque se tratava da "declaração de um direito do homem, que ninguém lhe pode negar",234 e "para que os maus finalmente não tenham de

\footnotetext{
${ }^{231}$ Annaes do Parlamento Brazileiro. Assembleia Constituinte. 1823. Tomo Sexto. Volume 6. Biblioteca Digital da Câmara dos Deputados. Centro de Documentação e Informação. Coordenação de Biblioteca. http://bd.camara.gov.br. Typografia do Imperial Instituto Artístico, rua primeiro de março n. 21, Rio de Janeiro, 1874, p. 49.

${ }^{232}$ Ib idem, p.50- 51.

${ }^{233} \mathrm{Ib}$ idem, p. 57.

${ }^{234} \mathrm{Ib}$ idem, p. 57.
} 
menos um recurso na sociedade para oprimir e vexar os bons, que aqui fazemos artigo de constituição de uma coisa que nunca o seria”,235.

José da Silva Lisboa alerta os deputados para a ignorância do povo brasileiro, que poderia interpretar a liberdade religiosa como liberdade de apostasia e perjuro, afirmando que "se se tratasse de fazer constituição para um estado de anjos e ainda de filósofos (o que é quimera), não havendo então perigo de abuso, talvez poderia passar sem inconveniente o parágrafo controverso, mas o caso é bem diverso" ${ }^{236}$. Para ele seria uma incongruência reconhecer a liberdade religiosa como um direito individual do cidadão brasileiro e afirmar, no artigo 15, fora das comunhões cristãs, que todas as demais seriam "apenas toleradas" 237 , sendo de rigor, portanto, estender a proteção do Estado a todas as demais religiões, o que constituiria um transbordamento dos limites contidos na procuração que os constituintes outorgaram aos deputados. É interessante aqui a compreensão da constituição como um instrumento de estabilidade sob o signo da linha ${ }^{238}$, direcionada, portanto, ao porvir, estabilidade esta ainda que relativa, por não significar imutabilidade. É precisamente isto que Silva Lisboa quer dizer quando aduz: “é evidente que a controversa linha da constituição não dá garantia contra tirania futura" ${ }^{239}$, deixando transparecer os próprios limites do direito e da constituição.

A sanção do projeto de lei sobre os governos provinciais suscitou discussão em torno de três temas, decorrentes das emendas apresentadas pelos deputados Vergueiro, Antônio Carlos e Montesuma, respeitantes à aplicação ou não das regras concernentes

\footnotetext{
${ }^{235}$ Annaes do Parlamento Brazileiro. Assembleia Constituinte. 1823. Tomo Sexto. Volume 6. Biblioteca Digital da Câmara dos Deputados. Centro de Documentação e Informação. Coordenação de Biblioteca. http://bd.camara.gov.br. Typografia do Imperial Instituto Artístico, rua primeiro de março n. 21, Rio de Janeiro, 1874, p. 57

${ }^{236} \mathrm{Ib}$ idem, p. 58.

${ }^{237} \mathrm{Ib}$ idem, p. 59.

${ }^{238}$ CATROGA, Fernando. Os passos do homem como restolho do tempo. Memória e fim do fim da história, $2^{\mathrm{a}}$ ed., Ed. Almedina, Coimbra, 2011.

${ }^{239}$ Annaes do Parlamento Brazileiro. Assembleia Constituinte. 1823. Tomo Sexto. Volume 6. Biblioteca Digital da Câmara dos Deputados. Centro de Documentação e Informação. Coordenação de Biblioteca. http://bd.camara.gov.br. Typografia do Imperial Instituto Artístico, rua primeiro de março n. 21, Rio de Janeiro, 1874, p. 60.
} 
aos governos provinciais ao Rio de Janeiro, à independência ou não do governador das armas e ao repasse de oito por cento das rendas líquidas das províncias ao Conselho.

A discussão sobre a inclusão do Rio de Janeiro no projeto teve lugar, em razão de ser esta província o lugar onde ficava o chefe do executivo e os ministros, bem como os tribunais de administração, justiça, fazenda e economia, sendo a sede do governo da nação e capital do Império. Montesuma defende que a omissão do Rio de Janeiro no projeto não foi obra do esquecimento do autor, mas, antes, uma deliberada exclusão, dada a sua natureza política especial, pois

\begin{abstract}
"todas as capitais tem uma governança própria e especial, não só porque nela existem os grandes tribunais e o poder executivo, mas até por dignidade do chefe da nação; tudo isto envolve a ideia essencial que na província da capital do império não se administram os seus fundos pelos mesmos canais porque se administram os das outras províncias" ${ }^{240}$.
\end{abstract}

Aliás, para ele, este tema versado no projeto de leis sobre os governos das províncias seria afeito à Constituição, de modo que nem "o sancionaria se visse que o projeto da constituição estava tão adiantado que em breve entrávamos na discussão dos governos provinciais, mas como vejo que não é fácil que cheguemos lá tão cedo, por isso é que hei de sancionar este decreto" ${ }^{\text {241 }}$. Da mesma forma pensava o deputado Carvalho e Mello, para quem "o remédio para acautelar semelhantes males é este provisório, porque ainda não chegamos ao artigo da constituição que deverá regular o governo das províncias"242. Para ele, "só na constituição se poderá examinar se nesta província mesmo deve haver conselho ou governador de província"243, lembrando que na França havia só o prefeito de polícia. Esta compreensão permite apreender bem

\footnotetext{
${ }^{240}$ Annaes do Parlamento Brazileiro. Assembleia Constituinte. 1823. Tomo Sexto. Volume 6. Biblioteca Digital da Câmara dos Deputados. Centro de Documentação e Informação. Coordenação de Biblioteca. http://bd.camara.gov.br. Typografia do Imperial Instituto Artístico, rua primeiro de março n. 21, Rio de Janeiro, 1874, p. 74.

${ }^{241}$ Ib idem, p. 74.

${ }^{242}$ Ib idem, p. 75.

${ }^{243} \mathrm{Ib}$ idem , p. 75.
} 
alguns traços de identificação e diferenciação entre a Constituição e as demais leis para os deputados da Assembleia Constituinte.

Com efeito, ainda que a matéria versada no projeto de lei sobre o governo das províncias requeresse uma envergadura constitucional, como a urgência da regulação dos negócios da administração provincial não podia esperar a longa tramitação do projeto de Constituição, os deputados admitiam que uma lei ordinária regulamentasse provisoriamente a matéria. $\mathrm{O}$ que se verifica nesta passagem é que a natureza dupla da Assembleia, constituinte e legislativa, entrelaça e pulveriza as diferenças entre a lei fundamental e as demais leis por ela editadas. E, principalmente, como a mobilidade dos interesses direcionava os sentidos atribuídos à constituição, sobrepondo camadas de memória política e jurídica.

A análise dos debates da Assembleia no contexto do processo de independência do Brasil confirma que a diferenciação entre direito e política não significa o isolamento desses dois sistemas ${ }^{244}$. Ao contrário. Andreia Slemian sustenta que os deputados constituintes foram artífices de uma tentativa de transformação da ordem política vigente através do direito. A autora cita como exemplo disso precisamente a aprovação pela Assembleia Constituinte de 1823 da lei de organização dos governos das Províncias e, como seu campo de investigação vai até 1834 , cita ainda a criação do Supremo Tribunal de Justiça e do Tesouro Público ${ }^{245}$. Neste sentido, quando da criação dos alicerces jurídicos para o novo Estado independente no Brasil, antes mesmo da sua existência efetiva como unidade estável, a apropriação da lei como fonte primária do

\footnotetext{
244 Tradução realizada a partir do original ("Verfassung als evolutionäre Errungenschaft". In: Rechthistorisches Journal. Vol. IX, 1990, pp. 176 a 220), cotejada com a tradução italiana de F. Fiore ("La costituzione come acquisizione evolutiva". In: ZAGREBELSKY, Gustavo. PORTINARO, Pier Paolo. LUTHER, Jörg. Il Futuro della Costituzione. Torino: Einaudi, 1996), por Menelick de Carvalho Netto, Giancarlo Corsi e Raffaele De Giorgi.

245 Slemian, Andréa. Sob o império das leis: Constituição e unidade nacional na formação do Brasil (1822-1834). Tese apresentada para o Programa de Pós-Graduação em História Social para obtenção do título de Doutor. Universidade de São Paulo. São Paulo, 2006.
} 
direito desdobrou-se na valorização da constituição como instrumento jurídico por excelência para estabelecer os critérios de organização política.

O artigo $9^{\circ}$ do projeto de Constituição, com o seguinte teor: "nenhum brasileiro será preso sem culpa formada, salvo nos casos expressos de lei"246 entraria em discussão, mas Antônio Carlos requereu o adiamento para que o artigo voltasse à Comissão de Constituição, que deveria cuidar de marcar expressamente os casos excepcionais em que seria admitida a prisão sem formação de culpa. Asseverava o relator do projeto: "não deixemos matéria tão séria para lei regulamentar"247, destacando com isso a supremacia da constituição em comparação com as demais leis. Na discussão do artigo 10 do projeto de Constituição, versando sobre a proibição da prisão sem formação de culpa, bem como sobre a admissibilidade da fiança em matéria penal, o deputado José Arouche de Toledo Rendon, identificado nas atas da Assembleia como Arouche Rendon, afirma que "este artigo é muito constitucional",248 (destaquei), acentuando o caráter liberal do artigo e quase que assimilando as noções de "constitucional" e "liberal"249.

Vale a pena transcrever trecho do discurso proferido pelo deputado França, defendendo a expressa menção ao juízo da formação da culpa como competente para a concessão da fiança, pois:

"seja qual for a lei que de futuro se haja de fazer sobre este objeto, deve ser concebida em sentido restrito a esta base constitucional... se deixarmos abertas na constituição para as leis regulamentares, serão tantas as

\footnotetext{
${ }^{246}$ Annaes do Parlamento Brazileiro. Assembleia Constituinte. 1823. Tomo Sexto. Volume 6. Biblioteca Digital da Câmara dos Deputados. Centro de Documentação e Informação. Coordenação de Biblioteca. http://bd.camara.gov.br. Typografia do Imperial Instituto Artístico, rua primeiro de março n. 21, Rio de Janeiro, 1874, p. 93.

${ }^{247} \mathrm{Ib}$ idem, p. 93.

${ }^{248} \mathrm{Ib}$ idem, p. 94.

249 A propósito da identificação entre liberalismo e constitucionalismo, José Reinaldo de Lima Lopes assevera que "no período de formação do Estado nacional brasileiro e na linguagem de vários dos participantes do processo de independência, liberalismo significa em primeiro lugar constitucionalismo" in LOPES, José Reinado de Lima. Iluminismo e jusnaturalismo no ideário dos juristas da primeira metade do Século XIX. In: JANCSÓ, István (org.). Brasil: formação do Estado e da Nação. São Paulo: Hucitec; Ed. Unijuí; Fapesp, 2003, p. 195-218.
} 
interpretações, que do texto não fique mais que a casca estéril sem nenhum suco de liberdade civil que nela queremos estabelecer" ${ }^{250}$.

É possível perceber a supremacia da norma constitucional neste discurso, comparativamente às normas prescritas nas leis regulamentares, com a associação da figura da constituição a uma maior garantia, se não de permanência, de estabilidade das disposições concernentes ao direito de liberdade civil, porque faz uma expressa referência ao futuro desse direito, que estaria melhor garantido por uma norma constitucional do que por uma outra norma qualquer. Além disso, fica explícito o princípio da constituição como parâmetro mínimo obrigatório de observância pelo legislador, que não poderia, para o futuro, afastar-se das bases constitucionalmente definidas para a concessão da fiança. Nota-se ainda uma preocupação com a variedade de possíveis interpretações normativas decorrentes de uma abertura semântica da norma constitucional, pela falta de uma disposição expressa quanto à competência para a concessão da fiança, possibilitando uma infinidade de entendimentos sobre o tema, a ponto de perder-se a essência - figurativamente associada ao suco da fruta - do direito de liberdade civil assegurado pela norma constitucional, remanescendo apenas a "casca estéril" de um direito oco, sem substância.

Na sessão do dia 15 de outubro discutiu-se ainda o artigo 11 do projeto de Constituição, que dispunha sobre as hipóteses excepcionais autorizadoras da prisão de qualquer brasileiro: flagrante delito e ordem de juiz ou resolução da sala dos deputados. $\mathrm{O}$ artigo excepcionava as prisões decorrentes das ordenanças militares concernentes à disciplina e recrutamento do exército. Os argumentos expendidos pelos deputados foram muito ricos em questões de fundo constitucional, notadamente quanto ao conceito de constituição como estatuto das liberdades, porém a supremacia constitucional

\footnotetext{
${ }^{250}$ Annaes do Parlamento Brazileiro. Assembleia Constituinte. 1823. Tomo Sexto. Volume 6. Biblioteca Digital da Câmara dos Deputados. Centro de Documentação e Informação. Coordenação de Biblioteca. http://bd.camara.gov.br. Typografia do Imperial Instituto Artístico, rua primeiro de março n. 21, Rio de Janeiro, 1874, p. 98.
} 
também foi invocada, como se observa do pronunciamento feito por Henriques de Rezende, que propõe a supressão da exceção contida no artigo, relativamente aos militares, porque "passado isto como artigo da constituição, jamais as legislaturas ordinárias poderão alterar essas leis ordenadas por um artigo constitucional, o qual, segundo este projeto, não se altera senão em uma convenção convocada $a d$ hoc ${ }^{\text {"251 }}$.

A noção de estabilidade, permanência e hierarquia das normas constitucionais, quando cotejadas com as demais normas constantes do ordenamento jurídico, fica evidenciada no discurso de Henriques de Rezende, porquanto, uma vez aprovada constitucionalmente a possibilidade de prisão dos militares sem situação de flagrância ou independentemente de prévia ordem escrita e fundamentada da autoridade competente, somente uma reforma constitucional poderia modificá-la, implicando uma maior dificuldade para a consecução desse desiderato, já que, dependente de uma convenção ad hoc, com requisitos difíceis de serem preenchidos, conforme previsto no projeto de Constituição, nos artigos 267 a 272 acima referidos.

Além disso, a percepção da constituição como paradigma de observância obrigatória pelos legisladores futuros também fica evidente no discurso proferido pelo deputado Vergueiro, ao comentar a emenda proposta por Paula e Mello para que as prisões do militares fossem feitas "segundo o espírito da constituição",252, pois eles também eram cidadãos e, por isso, mereciam igual proteção contra os abusos da tirania, já que as ordenanças militares eram "muito bárbaras e por isso acho preciso que na constituição se declare alguma garantia" ${ }^{253}$. Com efeito, Vergueiro afirma que a emenda apresentada pelo colega era inútil, pois "tem por objetivo apontar o princípio que os

\footnotetext{
${ }^{251}$ Annaes do Parlamento Brazileiro. Assembleia Constituinte. 1823. Tomo Sexto. Volume 6. Biblioteca Digital da Câmara dos Deputados. Centro de Documentação e Informação. Coordenação de Biblioteca. http://bd.camara.gov.br. Typografia do Imperial Instituto Artístico, rua primeiro de março n. 21, Rio de Janeiro, 1874, p. 101.

${ }^{252} \mathrm{Ib}$ idem, p. 100.

${ }^{253}$ Ib idem, p. 100.
} 
legisladores devem seguir... e os legisladores bem sabem que têm obrigação de seguir o espírito da constituição"254.

Outro tema que agitou o debate em torno do conceito de constituição como direito supremo foi o julgamento por meio de um corpo de jurados. Com efeito, o projeto de Constituição estabeleceu no seu artigo 13 que, "por enquanto" as causas cíveis não seriam julgadas pelos jurados e que esta restrição não forma artigo

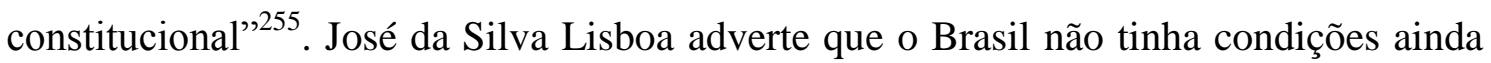
para o estabelecimento do julgamento por um corpo de jurados, ante a falta de luzes do povo brasileiro, razão pela qual defende a supressão do referido artigo, por parecer a ele que tal matéria só poderia ser objeto de lei regulamentar, depois da reforma ao código criminal e civil e, principalmente, pelo progresso de liberal educação do povo. O futuro Visconde Cairú critica a fórmula adotada pela Comissão de Constituição para ressalvar a aplicação do julgamento por jurados às causas cíveis. Como observado, os redatores do projeto, não obstante pretenderem excluir as causas cíveis do julgamento dos jurados, expressamente consignaram que tal exceção não formava artigo constitucional. Por isso mesmo Silva Lisboa indagava "para que, pois, se inseriu tal artigo na constituição? Isso não entendo",256.

Carneiro de Campos explicita o sentido da referida cláusula, asseverando que a restrição da adoção dos jurados no julgamento de matérias cíveis, nos termos dispostos na redação originalmente proposta no artigo 13 do projeto de Constituição, não contrariava a sua exposição anterior. Em outras palavras, apesar de sustentar a necessidade da adoção dos jurados sem qualquer restrição, admite a ressalva proposta

\footnotetext{
${ }^{254}$ Annaes do Parlamento Brazileiro. Assembleia Constituinte. 1823. Tomo Sexto. Volume 6. Biblioteca Digital da Câmara dos Deputados. Centro de Documentação e Informação. Coordenação de Biblioteca. http://bd.camara.gov.br. Typografia do Imperial Instituto Artístico, rua primeiro de março n. 21, Rio de Janeiro, 1874, p. 101.

${ }^{255}$ Ib idem, p. 119.

${ }^{256}$ Ib idem, p. 120.
} 
pelos redatores do projeto, tendo em vista a cláusula de que ela não formaria artigo constitucional. Mas o que isso queria dizer? Como um artigo da constituição não formaria artigo constitucional? Essa é precisamente uma das grandes riquezas que este trabalho permite explorar, a partir do ponto de vista dos diversos sentidos de constituição adotados pelos deputados na Assembleia Constituinte de 1823. Para ele “isto é como se dissesse que esta disposição não é perpétua, mas sim temporária e acomodada às nossas circunstâncias presentes" ${ }^{257}$, de modo que, uma vez removidos os obstáculos para a adoção dos jurados no julgamento das matérias cíveis e o Brasil tenha chegado ao estado de poder utilmente empregá-los em todos os processos, a restrição constante no projeto poderia ser reformada pelos meios ordinários, já que não formava artigo constitucional.

Na discussão dos artigos 14, 15 e 16, sobre a liberdade religiosa, Montesuma afirma que "às legislaturas ordinárias não é permitido fazer reformas em matérias constitucionais, sem se verificar, além de outras circunstâncias, o requisito de se acharem os representantes da nação munidos de poderes para isso"258. Com isso, ele quis enfatizar a dificuldade de se modicar uma norma constitucional, diferentemente do que se passava com a legislação ordinária, realçando a estabilidade das normas previstas na Constituição. Na sessão do dia 07 de novembro, Antônio Carlos oferece um artigo adicional ao projeto de Constituição, nos seguintes termos: "as restrições da liberdade religiosa não formam artigo constitucional e podem ser alteradas pelas legislaturas ordinárias" 259 , mas, depois de algum debate, que não foi registrado pelos taquígrafos, o mesmo autor ofereceu uma emenda ao seu aditamento, nos seguintes termos: "em vez

\footnotetext{
${ }^{257}$ Annaes do Parlamento Brazileiro. Assembleia Constituinte. 1823. Tomo Sexto. Volume 6. Biblioteca Digital da Câmara dos Deputados. Centro de Documentação e Informação. Coordenação de Biblioteca. http://bd.camara.gov.br. Typografia do Imperial Instituto Artístico, rua primeiro de março n. 21, Rio de Janeiro, 1874, p. 140.

${ }^{258}$ Ib idem, p. 202.

${ }^{259}$ Ib idem, p. 212.
} 
de alteradas, diga-se destruídas em todo ou em parte"260, tendo, depois disso, Silva Lisboa requerido o adiamento da discussão sobre a proposta de Antônio Carlos, por entender conveniente reservar a discussão para quando fossem tratar do artigo 268 do projeto de Constituição, "em que se declaram certos artigos não constitucionais"261, asseverando "não convir incorporar-se na constituição o que não for realmente constitucional" 262 , por lhe parecer "contradição nos termos, o ser ao mesmo tempo constitucional e não constitucional"263.

Para José da Silva Lisboa a nova proposta só manifestava, no seu entender, a compunção de espírito de Antônio Carlos, transformando o que antes defendia como "verdades eternas" em "verdades efêmeras", retirando a qualidade da "essência constitucional" dos artigos relativos à liberdade religiosa e deixando a sua alteração ao arbítrio das legislaturas futuras. Assevera que:

\begin{abstract}
"leis constitucionais... são as que antes se chamavam leis fundamentais do estado, que não se podem derrogar sem ruína do mesmo estado ou de sua forma de governo... fundamento de um edifício é o mesmo que o seu alicerce. As diferentes pedras de que este alicerce se compõe não se podem alterar e menos destruir sem cair por terra tal edifício" ${ }^{264}$.
\end{abstract}

Valendo-se da metáfora do arquiteto e do edifício, sustenta que as leis sobre a religião constituir-se-iam nas pedras angulares dessa construção, razão pela qual não podia admitir que futuros legisladores pudessem alterá-las e até destruí-las, no todo em parte, como referido na emenda ao artigo adicional, ambas de autoria de Antônio Carlos. Convinha que a Assembleia Constituinte e Legislativa do Brasil não chegasse ao ponto em que se precipitou a Assembleia Nacional da França de declarar mais do que a imutabilidade, a eternidade da Constituição, até impondo a pena de morte a quem

\footnotetext{
${ }^{260}$ Annaes do Parlamento Brazileiro. Assembleia Constituinte. 1823. Tomo Sexto. Volume 6. Biblioteca Digital da Câmara dos Deputados. Centro de Documentação e Informação. Coordenação de Biblioteca. http://bd.camara.gov.br. Typografia do Imperial Instituto Artístico, rua primeiro de março n. 21, Rio de Janeiro, 1874, p. 212.

261 Ib idem, p. 212.

${ }^{262} \mathrm{Ib}$ idem, p. 212.

${ }^{263} \mathrm{Ib}$ idem, p. 212.

${ }^{264}$ Ib idem, p. 212.
} 
propusesse a menor emenda contra ela, mas, ao mesmo tempo, não podia admitir o “extremo oposto de deixar mãos largas aos futuros legisladores para alteração ou destruição dos artigos da nossa constituição"265.

Como observamos linhas atrás, de fato, as Leis Fundamentais prepararam o terreno para a concepção moderna de constituição, mas, como observou Airton Seelaender, "defender a existência de uma continuidade histórica linear entre a "lex fundamentalis" e o conceito atual de "constituição" seria, porém, precipitado"266, dadas as diferenças destacadas entre uma e outra. Não obstante isso, a assertiva de José da Silva Lisboa situa o seu discurso mais próximo do passado colonial do que das transformações que estavam ocorrendo na engenharia social da independência brasileira $^{267}$.

Infelizmente, por conta da dissolução prematura da Assembleia, impossibilitouse a discussão dos artigos 267 a 272 do projeto de Constituição, dispondo sobre a natureza das normas constitucionais e sua forma de alteração, de modo que as referências encontradas de maneira esparsa nos Anais, pontualmente identificadas nas discussões de artigos como o do julgamento por jurados e da liberdade religiosa, são a única referência de que dispõe o pesquisador para tentar alcançar o sentido com que os deputados compreendiam esta distinção entre forma e conteúdo constitucionais.

\footnotetext{
265 Annaes do Parlamento Brazileiro. Assembleia Constituinte. 1823. Tomo Sexto. Volume 6. Biblioteca Digital da Câmara dos Deputados. Centro de Documentação e Informação. Coordenação de Biblioteca. http://bd.camara.gov.br. Typografia do Imperial Instituto Artístico, rua primeiro de março n. 21, Rio de Janeiro, 1874, p. 213.

266 SEELAENDER, Airton Cerqueira-Leite. Lei fundamental. Construção, funções e impactos de um conceito do antigo regime. Biblioteca Digital Revista Brasileira de Estudos Constitucionais - RBEC. Belo Horizonte, ano 3, n. 11, jul/set. 2009.

267 WEHLING, Arno. O Direito Constitucional como engenharia social no Brasil da independência. Métis: história\&cultura - v. 11, n. 21, p. 23-38, jan./jun. 2012.
} 


\section{CONSIDERAÇÕES FINAIS}

O presente trabalho foi construído sob as premissas sugeridas por António Manuel Hespanha para a definição de uma nova história constitucional ${ }^{268}$. Com efeito, ao longo do desenvolvimento do texto, sempre esteve presente a preocupação de superação de uma leitura dos textos constitucionais nos quais o sentido decisivo provenha unilateralmente de um "projeto constituinte". Antes disso, procurou-se promover um estudo dos contextos de recepção ou leitura destes textos constitucionais durante o processo de independência do Brasil. Para tanto, a análise dos contextos institucionais, especialmente da Assembleia Geral Constituinte e Legislativa do Brasil de 1823, dos contextos ideológicos e linguísticos, especialmente através de alguns periódicos editados no período e das discussões nas sociedades secretas, foram a bússola para a superação de uma lógica dogmática constitucional descontextualizada do seu sistema de produção e recepção.

Por outro lado, nos guiamos pela sugestão de Arno Wehling de que os anais parlamentares "dariam margem a uma criativa pesquisa sobre a maneira pela qual aquelas vertentes do constitucionalismo europeu (...) foram absorvidas e frequentemente combinadas, à luz dos interesses dos grupos locais"269 e mergulhamos na análise dos debates travados durante a Assembleia. Isso possibilitou um olhar, a partir de um ponto privilegiado de observação, em que o caráter multifacetário dos textos, proveniente da acumulação de camadas históricas de sentido, veio à tona, desconstruindo o mito de um

\footnotetext{
268 HESPANHA, António Manuel. "Questões de etiqueta jurídica: se, como e porque a história constitucional é uma história jurídica”. CARVALHO, José Murilo de; CAMPOS, Adriana Pereira (org.). Perspectivas da cidadania no Brasil Império. Rio de Janeiro, Civilização Brasileira, 2011, p. 355-376.

${ }^{269}$ Cf. WEHLING, Arno. O Direito Constitucional como engenharia social no Brasil da independência. Edição revista, corrigida e aumentada do estudo "Constitucionalismo e engenharia social no contexto da independência”, publicado na Revista do Instituto Histórico e Geográfico Brasileiro, n. 363, abr./jun. 1988 e em Pensamento político e elaboração constitucional no Brasil: estudos de história das idéias políticas. Rio de Janeiro: IHGB, 1994, p. 28.
} 
sentido único para a palavra constituição. Com efeito, desde uma ideia simplesmente descritiva - ligada ao conceito de lei fundamental do reino - até um conceito prescritivo - permeado de expectativas na construção de um novo ordenamento político, muito ligado a uma ideia de formação do Estado - a constituição foi mobilizada pelos atores no processo de independência para a conquista de suas posições. Neste ponto, o trabalho também é devedor das reflexões de Andreia Slemian ${ }^{270}$ sobre como foi possível estabelecer um novo pacto político no Brasil, no contexto da independência política em relação a Portugal, mimetizado sob a ideia de constituição e que teve uma extraordinária longevidade, até a Proclamação da República e a substituição por uma nova Constituição em 1891.

Com efeito, a criação e legitimação de um regime - que se pretendia representativo da nação e defensor dos seus direitos - inseriu o Império do Brasil num amplo movimento iniciado no final dos Setecentos, com as Revoluções Americana e Francesa, conferindo ao Poder Legislativo um papel de destaque nesta nova organização dos poderes, em substituição à velha ordem monárquica absolutista. Estes "novos tempos" mereceram atenção de inúmeros pesquisadores, com destaque para a análise de Reinhart Koseleck, que enxergou neste movimento de adaptação das realidades uma "aceleração do tempo histórico", com o rompimento da concepção cíclica do tempo pelos revolucionários, diante de um futuro cada vez mais imprevisível e marcado pela percepção de transitoriedade e provisoriedade das formas políticas ${ }^{271}$. Neste contexto, a emergência de valores constitucionais liberais aparecia como um anseio de

\footnotetext{
${ }^{270}$ SLEMIAN, Andréia. Sob o império das leis: Constituição e unidade nacional na formação do Brasil (1822-1834), Tese apresentada ao Programa de Pós-Graduação da Universidade de São Paulo em História Social para obtenção do título de Doutor, 2006.

${ }^{271}$ KOSELLECK, Reinhart. Futuro passado. Contribuição à semântica dos tempos históricos (traduzido do original alemão por Wilma Patrícia Maas, Carlos Almeida Pereira e César Benjamin), Rio de Janeiro, Contraponto editora, Ed. PUC-Rio, 2006.
} 
normalização do futuro, a partir das experiências vividas de ruptura e continuidade com o passado.

Vale destacar, entretanto, que, apesar da influência daqueles movimentos revolucionários, a estratégia de transferência da sede da monarquia portuguesa para o Brasil, forneceu ao constitucionalismo em Portugal e no Brasil uma outra temporalidade, que se traduz na apropriação dos mesmos conceitos de forma muitas vezes antagônica. Assim, como se destacou no Capítulo 1 deste trabalho, o liberalismo das Cortes Gerais e Extraordinárias da Nação Portuguesa, aos olhos do Brasil, representava o que havia de pior no despotismo do Antigo Regime, fundamentando, por isso mesmo, uma pretensão de convocação de Cortes exclusivamente brasileira. A polaridade entre a tradicional legitimidade monárquica e o parlamento - como nova esfera de representação política - merece destaque no caso luso-brasileiro, selando uma conflituosa história de construção de um regime de Monarquia Constitucional.

Concordamos com Andreia Slemian, quando nota, nos discursos parlamentares, quanto aos usos do conceito de constituição pelos deputados à Assembleia de 1823, uma referência dirigida ora ao passado, ora ao futuro, àquele novo instrumento de formação e organização de um novo Estado e governo. Com efeito, para alguns, a constituição seria a base de sustentação da união do império constituído pela natureza como um todo uno e indivisível, enquanto para outros, ao mesmo tempo, esta união reivindicava a preservação dos interesses das localidades na formação da nação pelo pacto futuro que a constituição representaria. Para Slemian, "a polissemia era, portanto, expressão de sua força no ambiente de luta política"272.

A centralidade conferida ao Poder Legislativo e, particularmente, à lei, como garantia da estabilidade jurídico-política da nação, é destacada na própria estrutura

\footnotetext{
${ }^{272}$ SLEMIAN, Andréia. Sob o império das leis: Constituição e unidade nacional na formação do Brasil (1822-1834), Tese apresentada ao Programa de Pós-Graduação da Universidade de São Paulo em História Social para obtenção do título de Doutor, 2006, p. 23.
} 
institucional da Assembleia de 1823, que era constituinte, mas também legislativa, o que contribuía ainda mais para a indefinição do alcance de sentido do termo constituição, a "lei das leis". A análise dos debates da Assembleia permitiu identificar um profícuo espaço de convivência e divergência política, com o desenvolvimento de uma experiência parlamentar importante, independentemente do fato de ter sido dissolvida. Não é outra a conclusão de Christian Lynch ao afirmar que "os anos que vão de 1821 a 1824 consistem no marco zero do Estado liberal brasileiro e, por conseguinte, do caminho que, algo aos solavancos, nos levaria à atual democracia liberal”273.

273 LYNCH, Christian Edward Cyril. Monarquia sem despotismo e liberdade sem anarquia: o pensamento político do Marquês de Caravelas. Belo Horizonte: Editora UFMG, 2014, p. 15. 
FONTES DOCUMENTAIS E BIBLIOGRAFIA

\section{ARQUIVOS}

Biblioteca Geral da Universidade de Coimbra (BGUC)

Biblioteca Nacional de Lisboa (BNL)

Biblioteca Central da Universidade de Brasília (BCEUNB)

Centro de Documentação e Informação da Câmara dos Deputados (CEDI Brasília)

\section{DOCUMENTAÇÃO IMPRESSA}

Apoio dos procuradores e do Ministério à súplica do povo pela convocação de uma Assembleia Geral (1822). BONAVIDES, Paulo; AMARAL, Roberto. Textos Políticos da História do Brasil. 3a. ed. v. 1. Brasília: Senado Federal, 2002, p. 592-594.

Carta dirigida a El Rei o Senhor D. João VI pela Junta Provisional do Governo Supremo do Reino estabelecida na cidade do Porto, 1820.

Coleção das leis do Império do Brasil. Rio de Janeiro, Tipografia Nacional, 12v.

Convocação do Conselho de Estado - Decreto do Príncipe Regente (1822). BONAVIDES, Paulo; AMARAL, Roberto. Textos Políticos da História do Brasil. 3a. ed. v. 1. Brasília: Senado Federal, 2002, p. 561.

Decreto de 12 de novembro de 1823. BONAVIDES, Paulo; ANDRADE, Paes de. História constitucional do Brasil. 9a. ed. Brasília: OAB, 2008, p. 557. 
Decreto de 13 de novembro de 1823. BONAVIDES, Paulo; ANDRADE, Paes de. História constitucional do Brasil. 9a. ed. Brasília: OAB, 2008, p. 559.

Documentos para a história da independência. Rio de Janeiro, Oficinas Gráficas da Biblioteca Nacional, 1923.

Documentos para a história das Cortes Geraes da Nação Portugueza, Tomo I (18201825), Lisboa: Imprensa Nacional, 1883.

Fala do Senado da Câmara dirigida ao Príncipe D. Pedro a propósito da convocação de uma Assembleia Geral solicitada pelo povo (1822). BONAVIDES, Paulo; AMARAL, Roberto. Textos Políticos da História do Brasil. 3a. ed. v. 1. Brasília: Senado Federal, 2002, p. 582-588.

Inventário analítico do Arquivo da Assembleia de 1823: descrição do acerva e sinopse de tramitação. Brasília, Câmara dos Deputados/Coordenação de Publicações, 1987.

Lições de Direito Público Constitucional para as escolas de Hespanha, por Ramon Salas, traduzidas, e dedicadas por D.G.L.D'Andrade: com o mesmo objeto à Regenerada Nação Portugueza, e oferecidas aos seus dignos representantes. Lisboa: Typografia Rollandiana, 1822.

Manifesto do Príncipe Regente aos brasileiros sobre os conflitos com Portugal e a expectativa de independência (1822). BONAVIDES, Paulo; AMARAL, Roberto. Textos Políticos da História do Brasil. 3a. ed. v. 1. Brasília: Senado Federal, 2002, p. 619-626.

Memorial patriotico dirigido aos ilustres, beneméritos, e liberaes Deputados, legítimos representantes da soberania, da leal nação portuguesa, em o Congresso Nacional de Cortes por A.I.S.T. Lisboa: Typografia Morandiana, 1821. 
MIRANDA, José Antônio de. Memória constitucional e política sobre o estado presente de Portugal e do Brasil. Rio de Janeiro: Imprensa Régia, 1821.

Proclamação constitucionalista do Governo Supremo do Reino. Porto, 1820.

Proclamação do Príncipe Regente prevenindo o povo "contra os inimigos da santa causa da liberdade do Brasil e sua independência” (1822). BONAVIDES, Paulo; AMARAL, Roberto. Textos Políticos da História do Brasil. 3a. ed. v. 1. Brasília: Senado Federal, 2002, p. 605.

Proclamação do Imperador D. Pedro I justificando a convocação de uma nova Assembleia Constituinte (1823). BONAVIDES, Paulo; AMARAL, Roberto. Textos Políticos da História do Brasil. 3a. ed. v. 1. Brasília: Senado Federal, 2002, p. 741-742. Quadras, a nossa Constituição. Manuscrito. s/ referências.

Recomendação de "união e tranquilidade" aos habitantes do Rio de Janeiro (1822). BONAVIDES, Paulo; AMARAL, Roberto. Textos Políticos da História do Brasil. 3a. ed. v. 1. Brasília: Senado Federal, 2002, p. 552-553.

Representação do povo do Rio de Janeiro ao Príncipe Regente em prol da convocação de uma Assembleia Geral (1822). BONAVIDES, Paulo; AMARAL, Roberto. Textos Políticos da História do Brasil. 3a. ed. v. 1. Brasília: Senado Federal, 2002, p. 571-579. Representação da Vila Real de Praia Grande (Niterói) pedindo a convocação de uma Assembleia Legislativa para o Brasil (1822). BONAVIDES, Paulo; AMARAL, Roberto. Textos Políticos da História do Brasil. 3a. ed. v. 1. Brasília: Senado Federal, 2002, p. 589-591.

Solicitação de convocação de uma Assembleia Geral - Requerimento do Senado da Câmara do Rio de Janeiro (1822). BONAVIDES, Paulo; AMARAL, Roberto. Textos Políticos da História do Brasil. 3a. ed. v. 1. Brasília: Senado Federal, 2002, p. 580-581. 
Fac-símiles de um trecho de carta de Dom Pedro I; de artigos da Constituição escritos pelo Conselheiro Francisco Gomes da Silva; e de trecho da Constituição escrito pelo mesmo Conselheiro, com emendas em caracteres maiores e mais fortes da caligrafia do Imperador. O Constitucionalismo de D. Pedro I no Brasil e em Portugal. Brasília: Ministério da Justiça, 1994, p. 35-68.

Anotações, adições e emendas do Conselheiro Francisco Gomes da Silva à Constituição do Império do Brasil para adaptá-la como Carta Constitucional da Monarquia Portuguesa. O Constitucionalismo de D. Pedro I no Brasil e em Portugal. Brasília: Ministério da Justiça, 1994, p. 69-120.

Anotações, adaptações e emendas à Constituição do Império do Brasil por Dom Pedro I sobre as adaptações sugeridas pelo Conselheiro Francisco Gomes da Silva. $O$ Constitucionalismo de D. Pedro I no Brasil e em Portugal. Brasília: Ministério da Justiça, 1994, p. 121-170.

Texto final da Carta Constitucional da Monarquia Portuguesa resultantes de adaptação, feita por Dom Pedro I e Conselheiro Francisco Gomes da Silva, da Constituição do Império do Brasil. O Constitucionalismo de D. Pedro I no Brasil e em Portugal. Brasília: Ministério da Justiça, 1994, p. 171-208.

1.1. Anais, Atas, atos normativos (leis, decretos, alvarás, regulamentos, portarias), Constituições e Diários de Assembleias

Bases da Constituição da Monarquia Portuguesa. Lisboa: Tipografia de J.F.M. de Campos, 1821. 
Constituição Política da Monarquia Hespanhola, promulgada em Cadiz em 19 de março de 1812, traduzida em portuguez por A.M.F. Coimbra: Real Imprensa da Universidade, 1820.

Constituição Política da Monarquia Portuguesa. Transcrição feita de acordo com o original, actualizando a grafia (Luís Filipe Correia Henriques). Lisboa: Chancelaria-mor da Corte e Reino, 1822.

Constituição Política do Império do Brasil (1824), acompanhada pelo Ato Adicional de 1834 e pela Lei de Interpretação de 1840. Brasília, Ministério do Interior/Fundação Projeto Rondon, 1986.

Constituições do Brasil, acompanhadas das emendas constitucionais e projetos. Rio de Janeiro, Imprensa Nacional, 1948.

Constituições americanas do século XIX (textos disponíveis no site Www.cervantesvirtual.com/portal/constituciones).

Diário da Assembleia Geral Constituinte e Legislativa do Império do Brazil: 1823. Brasília, Centro Gráfico do Senado Federal, 1973 (3 vols.) (disponível no site www.camara.gov.br).

Annaes do Parlamento Brazileiro. Assembleia Constituinte. 1823. Biblioteca Digital da Câmara dos Deputados. Centro de Documentação e Informação. Coordenação de Biblioteca. http://bd.camara.gov.br. Typografia do Imperial Instituto Artístico, rua primeiro de março n. 21, Rio de Janeiro, 1874 (6 vols.).

Decreto de 8 de junho de 1821. (disponível no site http://www.planalto.gov.br/CCIVIL_03/decreto/Historicos/DIM/DIM-8-6-1821.htm). 
Diário das Cortes Geraes da Nação Portugueza. Lisboa, anos de 1821: 4 tomos, ano de 1822: 3 tomos, ano de 1822-3: 3 tomos. (disponível no site www.debates.parlamento.pt).

O Constitucionalismo de D. Pedro I no Brasil e em Portugal. Brasília: Ministério da Justiça, 1994.

Projeto de Constituição no "Apostolado" e sua autoria. Revista do Instituto Histórico e Geográfico Brasileiro - RIHGB, Vol. LXXVII, 2a parte, p. 3-9, 1914.

Repertório, ou índice alfabetico das matérias compreendidas nos sete volumes dos Diarios das Cortes Geraes, Extraordiarias, e constituintes da Nação Portugueza, congregadas no anno de 1821; nos dous volumes da segunda legislatura do anno de 1822. Coimbra: Imprensa de Trovão \& Companhia, 1835.

RIALS, Stéphane. Textes Contitutionnels Français, 24 ed., Paris: Presses Universitaires de France, 2012.

\subsection{Periódicos}

A Malagueta.

A sentinela da liberdade.

Correio Braziliense.

Diário Constitucional.

Gazeta do Rio de Janeiro.

O Correio do Rio de Janeiro.

O Espelho. 
O Revérbero Constitucional Fluminense.

O Tamoio.

\section{BIBLIOGRAFIA GERAL}

ALEXANDRE, Valentim. Os sentidos do Império. Questão Nacional e Questão Colonial na Crise do Antigo Regime Português. Porto, Edições Afrontamento, 1993.

ARAÚJO, Ana Cristina Bartolomeu de. O "Reino Unido de Portugal, Brasil e Algarves" 1815-1822. Revista de História das Idéias, Vol. 14, publicação anual do instituto de História das Idéias da Faculdade de Letras da Universidade de Coimbra, 1992, pp. 233-259.

ARENDT, Hannah. Da revolução. Trad. Fernando Dídimo Vieira. Rev. Trad. Caio Navarro Toledo. Brasília e São Paulo: Universidade de Brasília e Ática, 1988.

. Entre o passado e o futuro. Trad. Mauro W. Barbosa, 5ª ed. São Paulo: Perspectiva, 2000.

BAILYN, Bernard. As Origens Ideológicas da Revolução Americana. Trad. Cleide Rapucci. Bauru: Edusc, 2003.

BARBOSA, Leonardo Augusto de Andrade. Processo Legislativo como discurso de justificação do direito: uma investigação sobre a circulação social do poder político na teoria discursiva do direito e da democracia. 2006. Dissertação (mestrado) Universidade de Brasília - UnB.

BARBOSA, Samuel Rodrigues. "Indeterminação do constitucionalismo imperial lusobrasileiro e o processo de independência do Brasil, 1821-1822”. s/ referências. 
BECCARIA, Cesare. Dos delitos e das penas. Trad. J. Cretella Jr. e Agnes Cretella, $4^{\mathrm{a}}$ ed. rev., São Paulo: Editora Revista dos Tribunais, 2009.

BENJAMIN, Walter. Teses sobre o conceito de história. LÖWY, Michael. Walter Benjamin: aviso de incêndio: uma leitura das teses "Sobre o conceito de história". Trad. Wanda Nogueira Caldeira Brant, [trad. das teses] Jeanne Marie Gagnebin e Marcos Lutz Müller. São Paulo: Boitempo, 2005.

BERBEL, Márcia Regina. A nação como artefato: deputados do Brasil nas cortes portuguesas (1821-1822). São Paulo: HUCITEC: FAPESP, 1999. - "Pátria e patriotas em Pernambuco (1817-1822): nação, identidade e vocabulário político”. JANCSÓ, István (org.). Brasil: Formação do Estado e da nação. São Paulo/Ijuí, Fapesp/Hucitec/Unijuí, 2003, p. 345-63.

. "Os apelos nacionais nas cortes constituintes de Lisboa (1821/22)." MALERBA, Jurandir (org.). A independência brasileira: novas dimensões. Rio de Janeiro: Editora FGV, 2006, p. 181-208.

BERBEL, Márcia; OLIVEIRA, Cecília Helena de Salles (orgs.). A experiência constitucional de Cádiz: Espanha, Portugal e Brasil. São Paulo: Alameda, 2012.

BOBBIO, Norberto. A teoria das formas de governo. Trad. de Sérgio Bath, $10^{\mathrm{a}}$ ed., Brasília: Editora Universidade de Brasília, 1997.

BOBBIO, Norberto et al. Dicionário de política. $13^{\mathrm{a}}$ ed., $4^{\mathrm{a}}$ reimpressão. Brasília: Editora Universidade de Brasília, 2010.

BONAVIDES, Paulo. Constitucionalismo luso-brasileiro: influxos recíprocos. Perspectivas Constitucionais, obra colectiva, I, Lisboa, 1996. 
BONAVIDES, Paulo; AMARAL, Roberto. Textos políticos da história do Brasil, Vol. I, $3^{a}$ ed., Brasília: Editora do Senado Federal, 2002.

Textos políticos da história do Brasil, Vol.

VIII, $3^{a}$ ed., Brasília: Editora do Senado Federal, 2002.

BONAVIDES, Paulo; ANDRADE, Paes de. História constitucional do Brasil, 9a . ed. Brasília: OAB, 2008.

CANECA, Frei Joaquim do Amor Divino. Frei Joaquim do Amor Divino Caneca. Org. e int. Evaldo Cabral de Mello. Coleção Formadores do Brasil. São Paulo: Ed. 34, 2001.

CANOTILHO, J.J. Gomes. Direito Constitucional e Teoria da Constituição, $7^{\mathrm{a}}$ ed., 12 reimp. Ed. Almedina, Coimbra, 2003.

Representação: entre a forma de governo representativa e a representação de nada no direito constitucional português. Res Publica: Cidadania e Representação Política em Portugal. 1820-1926/coord. Fernando Catroga, Pedro Tavares de Almeida. Assembleia da República: Biblioteca Nacional de Portugal, Lisboa, 2010, p. 142-153.

CARVALHO, José Murilo de. Cidadania no Brasil: o longo caminho, $9^{\mathrm{a}}$ ed. Rio de Janeiro: Civilização Brasileira, 2007.

A construção da ordem. A elite política imperial.

Brasília, UnB, 1981.

Teatro de sombras: a política imperial, $4^{\mathrm{a}}$ ed. Rio de Janeiro: UFRJ: Relumé Dumará, 2008.

CARVALHO, José Murilo de; CAMPOS, Adriana Pereira (org.). Perspectivas da cidadania no Brasil Império. Rio de Janeiro, Civilização Brasileira, 2011 
CARVALHO, Manuel Emílio Gomes de. Os deputados brasileiros nas Cortes gerais de 1821. Brasília, Senado Federal, 1979.

CARVALHO NETTO, Menelick de. A sanção no procedimento legislativo. Belo Horizonte: Del Rey, 1992.

A hermenêutica constitucional e os desafios postos aos direitos fundamentais. Jurisdição constitucional e os direitos fundamentais.

CARVALHO NETTO, Menelick de; SCOTTI, Guilherme. Os direitos fundamentais e a (in)certeza do direito - a produtividade das tensões principiológicas e a superação do sistema de regras. Editora Fórum, Belo Horizonte, 2011.

CATROGA, Fernando. Os passos do homem como restolho do tempo. Memória e fim do fim da história, $2^{\mathrm{a}}$ ed., Ed. Almedina, Coimbra, 2011.

- Ainda será a história mestra da vida? Estudos IberoAmericanos. PUCRS, Edição Especial, n. 2, p. 7-34, 2006.

. "Quimeras de um façanhoso império": o patriotismo constitucional e a independência do Brasil. Memória, escrita da história e cultura política no mundo luso-brasileiro. Rio de Janeiro, Ed. FGV, 2012, pp. 327.

Em nome da Nação. Res Publica: Cidadania e Representação Política em Portugal. 1820-1926/coord. Fernando Catroga, Pedro Tavares de Almeida. Assembleia da República: Biblioteca Nacional de Portugal, Lisboa, 2010, p. 20-59.

CATTONI, Marcelo. Constitucionalismo e História do Direito. Belo Horizonte: Pergamum, 2011.

Poder Constituinte e Patriotismo Constitucional. Belo Horizonte:

Mandamentos, 2006. 
CHAUÍ, Marilena. Brasil: mito fundador e sociedade autoritária. $6^{\mathrm{a}}$ ed. reimp. São Paulo: Fundação Perseu Abramo, 2006.

CHIARAMONTE, José Carlos. Metamorfoses do conceito de nação durante os séculos XVII e XVIII. JANCSÓ, István. Brasil: Formação do Estado e da nação. São Paulo/Ijuí, Fapesp/Hucitec/Unijuí, 2003, p. 61-91.

CONSTANT, Benjamin. Escritos de política. Trad. Eduardo Brandão; edição, introdução e notas Célia N. Galvão Quirino. São Paulo: Martins Fontes, 2005.

COSTA, Mário Júlio de Almeida. História do Direito Português. 5a ed. revista e actualizada. Coimbra: Editora Almedina, 2012.

DIERÓ, Pedro Eunápio da Silva. Fragmentos de Estudos da História da Assembléia Constituinte do Brasil. Brasília: Senado Federal, Conselho Editorial, 2006.

DIPPEL, Horst. História do Constitucionalismo Moderno: Novas Perspectivas. Trad. António Manuel Hespanha e Cristina Nogueira da Silva. Lisboa: Fundação Calouste, 2007. Inglaterra, Estados Unidos e França: Constitucionalismo e Soberania Popular. . El concepto de constitución em los orígenes del constitucionalismo norteamericano (1774-1776). Revista Fundamentos, n 6, 2010, pp. 25-83. O pensamento democrático na América e na França na época revolucionária: unidade e divergências. Tradução de José Emílio Medauar Ommati. s/ referências.

As ideias constitucionais americanas e francesas na Alemanha no final do Século XVIII. 
O surgimento do constitucionalismo moderno e as primeiras constituições latino americanas. Tradução de Paulo Sávio Peixoto Maia. s/ referência.

FAORO, Raymundo. Os donos do poder: formação do patronato político brasileiro. $16^{\mathrm{a}}$ ed. São Paulo: Globo, 2004.

FIORAVANTI, Maurizio. Costituzione, a cura di Carlo Galli, Il Mulino, Bologna, 1999.

. Las doctrinas de la Constitución em sentido material.

Traducción del italiano de María Valvidares, Universidad de Oviedo. Fundamentos -

Cuadernos monográficos de Tería del Estado, Derecho Público e Historia Constitucional (versão eletrônica), n ${ }^{\circ}$ 6. Oviedo: Junta General del Principado de Asturias, $\quad 2010, \quad$ p. $\quad 425-438 . \quad$ Disponível em http://www.unioviedo.es/constitucional/fundamentos/sexto/pdfs/10_fioravanti.pdf.

FRANCO, Afonso Arinos de Melo. Curso de direito constitucional brasileiro. V. 1. 2a. ed. Rio de Janeiro: 1968.

O pensamento constitucional brasileiro. Câmara dos

Deputados, Brasília, 1978.

. "Introdução". O Constitucionalismo de D. Pedro I no

Brasil e em Portugal. Ministério da Justiça, Arquivo Nacional, 1972.

GARRIGA, Carlos; SLEMIAN, Andréa. "Em trajes brasileiros": justiça e Constituição na América ibérica (c. 1750-1850). Revista de História, São Paulo, n. 169, p. 181-221, julho/dezembro, 2013.

GOMES, David Francisco Lopes. "Houve mão mais poderosa?”: a independência do Brasil como momento de passagem à modernidade. Dissertação (mestrado em direito). Universidade Federal de Minas Gerais - UFMG. Belo Horizonte, 2011. 
GRAHAM, Richard. "Construindo uma nação no Brasil no século XIX: visões novas e antigas sobre classe, cultura e Estado". Traduzido do artigo em inglês "Constructing a Nation in Nineteenth-Century Brazil: Old and New Views on Class, Culture and the State”, publicado no The Journal of the Historical Society, v. 1, n. 2-3, p. 17-56, 2001.

GRINBERG, Keila; SALLES, Ricardo (orgs). O Brasil Imperial, volume I: 1808-1831. Rio de Janeiro: Civilização Brasileira, 2009, p. 137-173.

GROSSI, Paolo. Mitologie giuridiche dela modernità. Milano: Giuffrè Editore, 2001.

GUERRA, François-Xavier. Modernidad e independências. Ensayos sobre las revoluciones hispânicas, $2^{\text {a }}$ ed. México, FCE, 1993.

. “A nação moderna: nova legitimidade e velhas identidades”. JANCSÓ, István. Brasil: Formação do Estado e da nação. São Paulo/Ijuí, Fapesp/Hucitec/Unijuí, 2003, p. 33-60.

HABERMAS, Jürgen. $O$ discurso filosófico da modernidade: doze lições. Trad. Luiz Sérgio Repa, Rodnei Nascimento. São Paulo: Martins Fontes, 2000.

HAMILTON, Alexander; JAY, John; MADISON, James. O Federalista. Rio de Janeiro: Editora Nacional de Direito, 1959.

HARTOG, François. Regimes de historicidade: presentismo e experiências do tempo. Belo Horizonte: Autêntica Editora, 2013. Tempo, história e a escrita da história: a ordem do tempo. Revista de História do Departamento de Historia da USP, 148 (1º-2003), p. 09-34.

HEES, Felipe. O conceito de Constituição na independência e na proclamação da República: uma comparação. Revista história, histórias, do Programa de PósGraduação em história - UnB. Brasília, vol. 1, n. 1, 2013. 
HEGEL, Georg Wilhelm Friedrich. Filosofia da História. Trad. Maria Rodrigues e Hans Harden. $2^{\text {a }}$ ed., reimpressão, Brasília, Editora Universidade de Brasília, 2008.

HESPANHA, António Manuel. Guiando a mão invisível. Direitos, Estado e lei no liberalismo monárquico português. Coimbra: Editora Almedina, 2004.

O constitucionalismo monárquico português. Breve

sintese. [S.1.: s.n., 1985?].

Sob o signo de Napoleão. A súplica constitucional de

1808. Revista Brasileira de Direito Comparado. Instituto de Direito Comparado LusoBrasileiro, 34(2010), 47-80.

Panorama Histórico da cultura jurídica européia.

Publicações Europa-América, Sintra, 1997.

. "Pequenas Repúblicas, grandes Estados. Problemas de organização política entre antigo regime e liberalismo”. JANCSÓ, István (org.). Brasil. Formação do Estado e da Nação. São Paulo/Ijuí, Hucitec/Fapesp/Unijuí, 2003, p. 93108.

. "Questões de etiqueta jurídica: se, como e por que a história constitucional é uma história jurídica". CARVALHO, José Murilo de; CAMPOS, Adriana Pereira (org.). Perspectivas da cidadania no Brasil Império. Rio de Janeiro, Civilização Brasileira, 2011, p. 355-376.

HESPANHA, A.M. (dir.); SILVA, Cristina Nogueira da. Fontes para a história constitucional portuguesa, Lisboa, Faculdade de Direito da UNL, 2004 (em publicação no site da Biblioteca Nacional de Lisboa). 
HESSE, Konrad. A força normativa da Constituição. Sérgio Antônio Fabris Editor. Porto Alegre, 2009.

HOBSBAWM, Eric. A era das revoluções 1789-1848, 25ª ed. Revista, $3^{\mathrm{a}}$ reimpressão, Rio de Janeiro, Paz e Terra, 2011.

HOLANDA, Sérgio Buarque de. Raízes do Brasil. ed. comemorativa 70 anos. São Paulo: Companhia das Letras, 2006.

HOLANDA, Sérgio Buarque de (org.). História geral da civilização brasileira. t. 2, v 1. São Paulo: Difel, 1970.

HOLANDA, Sérgio Buarque de (dir.). História Geral da Civilização Brasileira. t. II, v. 3, O Brasil monárquico - O processo de emancipação. Rio de Janeiro: Bertrand Brasil, 2003.

JANCSÓ, István (org.). Brasil. Formação do Estado e da Nação. São Paulo/Ijuí, Hucitec/Fapesp/Unijuí, 2003.

JANCSÓ, István (org.). Independência do Brasil: história e historiografia. São Paulo, Hucitec/Fapesp, 2005.

JANCSÓ, István; PIMENTA, João Paulo G. Peças de um mosaico. Ou apontamentos para o estudo da emergência da identidade nacional brasileira. Revista de História das Idéias, Vol. 21, publicação anual do instituto de História das Idéias da Faculdade de Letras da Universidade de Coimbra, 2000, pp. 389-440.

JEFFERSON, Thomas; PAINE, Thomas; HAMILTON, Alexander; MADISON, James; JAY, John; TOCQUEVILLE, Alexis de. Escritos políticos. 2a. ed. São Paulo: Abril Cultural, 1979, p. 41-83. 
KOSELLECK, Reinhart. Futuro passado. Contribuição à semântica dos tempos históricos (traduzido do original alemão por Wilma Patrícia Maas, Carlos Almeida Pereira e César Benjamin), Rio de Janeiro, Contraponto editora, Ed. PUC-Rio, 2006. . "Uma história dos conceitos: problemas teóricos e práticos." Estudos Históricos, Rio de Janeiro, vol. 5, n. 10, 1992, p. 134-146.

KOSELLECK, Reinhart et al. O conceito de história. Tradução René E. Gertz. Belo Horizonte: Autêntica Editora, 2013 (Coleção História e Historiografia, 10).

LIMA, Manuel de Oliveira. D. João VI no Brasil. Rio de Janeiro, Of. Gráf. do Jornal do Brasil, 1909. (Rio de Janeiro, José Olympio, 1945, 3v.).

O movimento da independência (1821-1822). Belo Horizonte/São Paulo, Itatiaia/Edusp, 1989 (1922).

Império brasileiro: 1822-1889. São Paulo,

Melhoramentos.

LIMA SOBRINHO, Barbosa (et al.). A Constituinte de 1823. Obra comemorativa do Sesquicentenário da Instituição Parlamentar. Brasília: Senado Federal, 1973.

LOPES, José Reinaldo de Lima. "Iluminismo e jusnaturalismo no ideário dos juristas da primeira metade do século XIX". JANCSÓ, István (org.). Brasil. Formação do Estado e da nação. São Paulo/Ijuí, Hucitec/Fapesp/Ijuí, 2003, p. 195-218.

LYNCH, Christian Edward Cyril. O Momento Monarquiano - O Poder Moderador e o Pensamento Político Imperial. Tese (Doutorado em Ciência Política). Instituto Universitário de Pesquisas do Rio de Janeiro - IUPERJ, Rio de Janeiro, 2007. 
anarquia: o pensamento político do Marquês de Caravelas. Belo Horizonte: Editora UFMG, 2014.

LYRA, Maria de Lourdes Viana. A utopia do poderoso império - Portugal e Brasil: bastidores da política 1798-1822. Rio de Janeiro: Sette Letras, 1994.

LUHMANN, Niklas. "La Constituzione come acquisizione evolutiva". ZAGREBELSKY, Gustavo; PORTINARO, Pier Paolo e LUTHER, Jörg (org.). Il Futuro dela Costituzione. Torino: Eianudi, 1996.

LUSTOSA, Isabel. D. Pedro I. Coleção perfis brasileiros. Org. Elio Gaspari e Lilian M. Schwarcks. Cia das Letras.

MCFARLANE, Anthony. "Independências americanas na era das revoluções: conexões, contextos, comparações." MALERBA, Jurandir (org.). A independência brasileira: novas dimensões. Rio de Janeiro: Editora FGV, 2006, p. 387-417.

MAIA, Paulo Sávio Peixoto. "Sobre o conceito e a função da Constituição dos modernos". Revista Controle, Vol. VII, n. 2, Dezembro, 2009.

MALERBA, Jurandir. A corte no exílio: civilização e poder no Brasil às vésperas da Independência (1808-1821). São Paulo: Companhia das Letras, 2000.

MALERBA, Jurandir (org.). A independência brasileira: novas dimensões. Rio de Janeiro: Editora FGV, 2006.

. "Esboço crítico da recente historiografia sobre a independência do Brasil (1980-2002)." MALERBA, Jurandir (org.). A independência brasileira: novas dimensões. Rio de Janeiro: Editora FGV, 2006, p. 19-52.

MARQUES, Mário Reis. Codificação e Paradigmas da Modernidade. Coimbra Editora, Coimbra, 2003. 
MARQUES, Raphael Peixoto de Paula. "História semântica de um conceito. A influência inglesa do século XVII e norte-americana do século XVIII na construção de sentido de Constituição como Paramount law”. Brasília a. 43, n. 172, out./dez. 2006.

MARRAMAO, Giacomo. Passado e futuro dos direitos humanos: da "ordem póshobbesiana" ao cosmopolitismo da diferença. XVI Congresso Nacional do Conselho Nacional de Pesquisa e Pós-graduação em Direito (CONPEDI). Conferência. Belo Horizonte: Puc-Minas, 15 de novembro de 2007.

MAXWELL, Kenneth. "Por que o Brasil foi diferente? O contexto da independência". MOTA, Carlos G. (org.). Viagem incompleta. A experiência brasileira 1500-2000. São Paulo, SENAC, 2000, p. 177-195.

MELLO, Evaldo Cabral. A outra Independência: o federalismo pernambucano de 1817 a 1824. São Paulo: Ed. 34, 2004.

MIRANDA, Jorge. Manual de Direito Constitucional, $2^{\mathrm{a}}$ ed. Coimbra, Coimbra Editora, 1982.

. O constitucionalismo liberal luso-brasileiro. Lisboa: Comissão

Nacional para as Comemorações dos Descobrimentos Portugueses, 2001.

MOHNHAUPT, Heinz; GRIMM, Dieter. Constituição - História do conceito desde a antiguidade até os nossos dias. Belo Horizonte: Livraria Tempus, 2012.

MOTA, Carlos Guilherme. (org.). 1822: dimensões.

MORAES, Alexandre José de Mello. História do Brasil-Reino e do Brasil-Império. t. 1. São Paulo: Ed. Universidade de São Paulo, 1982. História do Brasil-Reino e do Brasil-Império. t.

2. São Paulo: Ed. Universidade de São Paulo, 1982. 
NEVES, Castanheira. Teoria do Direito. Lições proferidas no ano lectivo de 1998/1999, policopiado, Coimbra 1998.

NEVES, Lúcia Maria Bastos Pereira das. Corcundas e constitucionais: a cultura e política da independência (1820-1822). Rio de Janeiro: Revan/FAPERJ, 2003.

NEVES, Marcelo. A constitucionalização simbólica. São Paulo: Martins Fontes, 2007.

NOVAIS, Fernando Antônio. Aproximações: estudos de história e historiografia. São Paulo: Cosac Naify, 2005.

. “As dimensões da Independência”. MOTA, Carlos

Guilherme (org.). 1822: dimensões, p. 15-26.

OST, François. O tempo do direito. Trad. Élcio Fernandes. Bauru: EDUSC, 2005.

PAIXÃO, Cristiano. Modernidade, Tempo e Direito. Belo Horizonte: Del Rey, 2002. - "Tempo presente e regimes de historicidade: perspectivas de investigação para a história do direito". V Congresso Brasileiro de História do Direito. Curitiba, 31 de agosto de 2011.

. "Autonomia, democracia e poder constituinte: disputas conceituais na experiência constitucional brasileira (1964-2014)”. Escrito inédito.

PAIXÃO, Cristiano; BIGLIAZZI, Renato. História constitucional inglesa e norteamericana: do surgimento à estabilização da forma constitucional. Brasília: Ed. Universidade de Brasília: Finatec, $1^{\mathrm{a}}$ reimpressão, 2011.

PAIXÃO, Cristiano; MAIA, Paulo Sávio Peixoto. História da Constituição como história conceitual: Marbury v. Madison e o surgimento da supremacia constitucional. Revista Acadêmica - Faculdade de Direito do Recife, v. LXXXI, p. 156-175, 2009. 
PIMENTA, João Paulo G. Estado e Nação no Fim dos Impérios Ibéricos no Prata (1808-1828). São Paulo: Hucitec/Fapesp, 2002.

. "A política hispano-americana e o império português

(1810-1817): vocabulário política e conjuntura." JANCSÓ, István (org.). Brasil.

Formação do Estado e da Nação. São Paulo/Ijuí, Hucitec/Fapesp/Unijuí, 2003, p. 123139.

PRADO JÚNIOR, Caio. Formação do Brasil Contemporâneo: Colônia. 5a. ed. São Paulo: Brasiliense, 1957.

Evolução política do Brasil: colônia e império, $20^{\mathrm{a}}$ ed. São

Paulo: Brasiliense, 1993.

RIBEIRO, Maria Manuela Tavares. Portugal e Brasil - a modernidade constitucional.

Separata dos Anais II Simpósio Internacional. Estados americanos, relações continentais e intercontinentais. Editora Universitária. Passo Fundo, 1997.

RICOEUR, Paul. A memória, a história, o esquecimento. Campinas: Editora UNICAMP, 2007.

RODRIGUES, José Honório. A Assembleia Constituinte de 1823. Petrópolis: 1974. Independência: revolução e contra-revolução. São

Paulo: Perspectiva, 1972, 5 v.

ROSENFELD, Michel. A identidade do sujeito constitucional. Trad. Menelick de Carvalho Netto. Belo Horizonte: Mandamentos, 2003.

ROUSSEAU, Jean-Jacques. Do Contrato Social. Os Pensadores, v. 1. São Paulo: Nova Cultura, 1997, p. 45-243. 
SCHIAVINATTO, Iara Lis. "Questões de poder na fundação do Brasil: o governo dos homens e de si (1780-1830)." MALERBA, Jurandir (org.). A independencia brasileira: novas dimensões. Rio de Janeiro: Editora FGV, 2006.

SCHULTZ, Kirsten. “A era das revoluções e a transferencia da corte portuguesa para o Rio de Janeiro (1790-1821)". MALERBA, Jurandir (org.). A independencia brasileira: novas dimensões. Rio de Janeiro: Editora FGV, 2006.

SEELAENDER, Airton Cerqueira-Leite. Lei Fundamental. Construção, funções e impactos de um conceito do antigo regime. Biblioteca Digital Revista Brasileira de Estudos Constitucionais - RBEC, Belo Horizonte, ano 3, n. 11, jul./set. 2009. Disponível em : http://www.editoraforum.com.br.

SIEYÈS, Emannuel. A Constituinte Burguesa - O que é o Terceiro Estado? Org. e Int. Aurélio Wander Bastos. Trad. Norma Azeredo. 4a. edição. Rio de Janeiro: Lumen Júris, 2001.

SILVA, Ana Rosa Cloclet da. Inventando a nação: intelectuais ilustrados e estadistas luso-brasileiros na crise do Antigo Regime Português (1750-1822). São Paulo: Hucitec; Fapesp, 2006.

SILVA, Maria Beatriz Nizza da. Movimento constitucional e separatismo no Brasil (1821-1823). Lisboa: Horizonte, 1988.

A repercussão da revolução de 1820 no Brasil eventos e ideologias. Revista de História das Idéias. v. 2. 1979, p. 1-52.

SLEMIAN, Andréa. Sob o império das leis: Constituição e unidade nacional na formação do Brasil (1822-1834). Tese (Doutorado em História Social). Universidade de São Paulo - USP, São Paulo, 2006. 
SOARES, Rogério Ehrhardt. O conceito ocidental de Constituição. Revista de Legislação e Jurisprudência, 3743 e 3744, Coimbra Editora, Coimbra, 1987, p. 36-39 e 69-73.

STOURZH, Gerald. "Constitution: Changing Meanings of the Term from the Early Seventeenth to the Late Eighteenth Century". BALL, Terence; POCOCK, J.G.A.. Conceptual Change and the Constitution, Lawrence KS, 1988, p. 35-54.

VARNHAGEN, Francisco Adolfo de. História da Independência do Brasil - até o reconhecimento pela antiga metrópole, compreendendo, separadamente, a dos sucessos ocorridos em algumas províncias até essa data. 3a. ed. São Paulo: Edições Melhoramentos, 1957.

WEHLING, Arno. O Direito Constitucional como engenharia social no Brasil da independência. Edição revista, corrigida e aumentada do estudo "Constitucionalismo e engenharia social no contexto da independência", publicado na Revista do Instituto Histórico e Geográfico Brasileiro, n. 363, abr./jun. 1988 e em Pensamento político e elaboração constitucional no Brasil: estudos de história das idéias políticas. Rio de Janeiro: IHGB, 1994. 